\title{
A multidisciplinary reconstruction of Palaeolithic nutrition that holds promise for the prevention and treatment of diseases of civilisation
}

\author{
Remko S. Kuipers $^{1}$, Josephine C. A. Joordens ${ }^{2}$ and Frits A. J. Muskiet ${ }^{1 *}$ \\ ${ }^{1}$ Laboratory Medicine, University Medical Center Groningen (UMCG), Groningen, The Netherlands \\ ${ }^{2}$ Human Origins Group, Faculty of Archaeology, Leiden University, Leiden, The Netherlands
}

\begin{abstract}
Evolutionary medicine acknowledges that many chronic degenerative diseases result from conflicts between our rapidly changing environment, our dietary habits included, and our genome, which has remained virtually unchanged since the Palaeolithic era. Reconstruction of the diet before the Agricultural and Industrial Revolutions is therefore indicated, but hampered by the ongoing debate on our ancestors' ecological niche. Arguments and their counterarguments regarding evolutionary medicine are updated and the evidence for the longreigning hypothesis of human evolution on the arid savanna is weighed against the hypothesis that man evolved in the proximity of water. Evidence from various disciplines is discussed, including the study of palaeo-environments, comparative anatomy, biogeochemistry, archaeology, anthropology, (patho)physiology and epidemiology. Although our ancestors had much lower life expectancies, the current evidence does neither support the misconception that during the Palaeolithic there were no elderly nor that they had poor health. Rather than rejecting the possibility of 'healthy ageing', the default assumption should be that healthy ageing posed an evolutionary advantage for human survival. There is ample evidence that our ancestors lived in a land-water ecosystem and extracted a substantial part of their diets from both terrestrial and aquatic resources. Rather than rejecting this possibility by lack of evidence, the default assumption should be that hominins, living in coastal ecosystems with catchable aquatic resources, consumed these resources. Finally, the composition and merits of so-called 'Palaeolithic diets', based on different hominin niche-reconstructions, are evaluated. The benefits of these diets illustrate that it is time to incorporate this knowledge into dietary recommendations.
\end{abstract}

Key words: Palaeolithic nutrition: Disease prevention: Disease treatment: Dietary recommendations: Evolutionary medicine: Healthy ageing

\section{Introduction}

In the Origin of Species ${ }^{(1)}$, Darwin recognised that there are two forces of evolution, i.e. natural selection and the conditions of existence, where the latter was considered the most powerful ${ }^{(2)}$. For example, important steps in evolution are the origin of eukaryotic life approximately $1 \cdot 6-2 \cdot 7$ billion years ago ${ }^{(3,4)}$ and the appearance of photosynthetic cyanobacteria that began to oxygenate the atmosphere about 2400 million years ago (Mya) ${ }^{(5)}$. However, there was relatively little alteration in the design of life forms before the Cambrian explosion about 600 Mya. Only when the oxygen tension in the atmosphere rose above the Pasteur point did aerobic metabolism become thermodynamically possible ${ }^{(6)}$, resulting in an explosion from simple prokaryotics to a diversity of eukaryotic life forms ${ }^{(7)}$.
During the past millions of years of evolution, with relatively little alteration in life forms and environmental circumstances, the human genome has become optimally adapted to its local environment ${ }^{(8-11)}$. In other words, our genome may have reached a state of homeostasis, defined as the 'optimal interaction between environment and genome' or 'nature in balance with nurture', to support optimal survival for reproductive success. The aetiologies of many typically Western diseases, also known as diseases of affluence or civilisation, have been attributed to the disturbance of this delicate balance, secondary to the rapid changes in the conditions of existence, while our genome has remained basically unchanged since the beginning of the Palaeolithic era. The former include changes in physical activity, stress, sleep duration, environmental pollution and others ${ }^{(12,13)}$,

Abbreviations: AA, arachidonic acid; ALA, $\alpha$-linolenic acid; en\%, percentage energy; EQ, encephalisation quotient; Kya, thousand years ago; LA, linoleic acid; MCSFA, medium-chain SFA; Mya, million years ago; RAR, retinoic acid receptor; RXR, retinoid X receptor; TR, thyroid hormone receptor; VDR, vitamin $D$ receptor.

*Corresponding author: Dr Frits A. J. Muskiet, fax +31 50361 2290, email f.a.j.muskiet@umcg.nl 
but one of the most rapidly changing conditions of existence has been the human diet.

Since the onset of the Agricultural Revolution, some 10 thousand years ago (Kya), and notably in the last 200 years following the start of the Industrial Revolution, humans have markedly changed their dietary habits. Consequently, it has been advocated that the current pandemic of diseases of civilisation results in part from the mismatch between the current diet and our Palaeolithic genome. In other words, 'we are what we eat, but we should be what we ate $e^{,(14,15)}$. The ensuing poorly adapted phenotype may find its origin as early as in the fetal period ${ }^{(16,17)}$ and possibly as far back as in the maternal grandmother's womb ${ }^{(18)}$. This phenotype might be laid down in, inherently labile, epigenetic marks that are meant for the short- and intermediate-term adaptation of a phenotype to the conditions of existence. With clear evolutionary advantages they may become transmitted to the next generations as a memory of the environmental conditions that can be expected after birth ${ }^{(19)}$. They thereby give rise to a seemingly high contribution of genetics in some of the associated 'typically Western' degenerative diseases, which are in fact complex diseases that by definition do not inherit by Mendel's law, illustrating that epigenetic marks can also become erased.

From a pathophysiological point of view, the poorly adapted phenotype in Western countries, ensuing from the conflict between the changing lifestyle and our Palaeolithic genome, centres on chronic low-grade inflammation and the metabolic syndrome (also named the insulin resistance syndrome), which are risk factors for many of the diseases and conditions typical for affluent countries, such as CVD, type 2 diabetes mellitus, osteoporosis, certain types of cancer (notably colon, breast, prostate), fertility problems (polycystic ovary syndrome), pregnancy complications (gestational diabetes, pre-eclampsia), some psychiatric diseases (major and postpartum depression, schizophrenia, autism) and neurodegenerative diseases (Alzheimer's disease, Parkinson's disease) ${ }^{(20-22)}$. The genetically determined flexibility to adapt to a changing environment appears to have been exceeded and the genetically most vulnerable have become sick first, but ultimately all individuals will become sick with increasing dose and exposure time.

\section{Environment, nutrients and their interaction with the genome}

Adjustment of the DNA base sequence is a slow process that in an individual cannot support adaptation to environmental changes occurring at intermediate or rapid pace. Flexibility for rapid adaptation is provided by genetically encoded mechanisms that allow adjustment of phenotype by epigenetics and by the interaction of the environment with sensors, such as those of the sensory organs, but also by the many that remain unnoticed ${ }^{(23-25)}$. The role of nutrients in (epi)genetics and their direct interaction with the genome have become increasingly acknowledged $^{(26)}$. Examples of such nutrients are iodine, Se, vitamins $\mathrm{A}$ and $\mathrm{D}$, and $n$-3-fatty acids, which are direct or indirect ligands of the thyroid hormone receptor (TR), retinoid $\mathrm{X}$ receptor (RXR), retinoic acid receptor (RAR), vitamin D receptor (VDR) and PPAR. Homodimerisation and heterodimerisation of these receptors facilitate gene transcription and thereby keep our phenotype optimally adapted to the reigning conditions of existence. The roles of these nutrients, their respective receptors and the interaction between their receptors are indicative of the importance of their dietary presence and of a certain balance between their dietary intakes to arrive at optimal interaction with the genome. Lessons for this optimal interaction, and hence for the development of randomised controlled trials aiming at the study of diet or lifestyle, rather than single nutrients, might derive from knowledge on human evolution and the conditions of existence to which our ancestors have been exposed. These lessons might provide us with valuable information on what we should genuinely define as a 'healthy diet'.

\section{Evolutionary medicine}

The concept that a thorough understanding of evolution is important in the prevention and treatment of (human) diseases has long been recognised. For example, in the early 1960s it was stated that "nothing in biology makes sense except in the light of evolution' ${ }^{(27)}$, while in ethology, a distinction was made between proximate and ultimate (also named evolutionary) causes ${ }^{(28)}$. Proximate explanations provide a direct mechanism for certain behaviour in an individual organism. They explain how biomolecules induce certain behaviour or, for example, an allergic reaction. Proximate explanations, however, provide insufficient information to answer the question why this behaviour or this allergic reaction occurred. Ultimate explanations provide answers explaining why things happen from an evolutionary point of view. Many, if not all, diseases can become explained by both proximate and ultimate explanations. The science searching for the latter explanations has become known as 'evolutionary medicine'. Unfortunately, modern medicine deals mostly with proximate explanations ${ }^{(29,30)}$, while ultimate explanations seem more prudent targets for long-time disease prevention $^{(29)}$.

The term 'evolutionary medicine' (also named Darwinian medicine) was launched by Randolph M. Nesse and George C. Williams ${ }^{(31,32)}$. They provided evolutionary answers for the understanding of human diseases. Many diseases do not result from a single biological, anatomical or physiological abnormality, but rather from a complex web of interactions. They often reflect the collateral damage of the survival and reproduction strategies of our genes and the genes of other organisms in our environment. 
The resulting disease manifestations include the outcomes of human defence mechanisms to clear foreign pathogens and the collateral damage of conflicts and trade-offs between humans and foreign invaders. Examples often overlooked are coincidence, in which diseases may result from imperfections of human evolution, and exaptation, in which a feature is not acquired in the context of any function to which it might eventually be put ${ }^{(33)}$. For example, the equilibrium between the not yet full-grown, but yet relatively large, brain of a newborn and the small birth canal in its turn is constrained by an upright posture and provides an example of a trade-off in human evolution. The location of the birth canal in its turn provides an example of an evolutionary coincidence that urges to deal with an, in retrospect, imperfect evolutionary design. These examples illustrate that evolution builds on the past: it is not possible to start a completely new design from scratch, which argues against 'intelligent design'. The most important example of an evolutionary explanation for human disease, however, comes from the mismatch between our slowly adapting genome and the rapidly changing environment, notably our diet.

Evolutionary medicine argues that the chronic degenerative diseases causing most morbidity and mortality in affluent countries occur because of the current mismatch between the rapidly changing conditions of existence and our Palaeolithic genome ${ }^{(34)}$. These mismatches will persist, notably in the light of our long generation time. The genetic adjustments needed to adapt to the new environment are also unlikely to occur, since the mismatch exerts little selection pressure. That is, they do not cause death before reproductive age, but rather reduce the numbers of years in health at the end of the life cycle ${ }^{(35)}$. Consequently, evolutionary medicine acknowledges a return to the lifestyle before the onset of the Agricultural Revolution as translated to the culture of the 21th century and as popularised by the expression: 'how to become a 21th century hunter-gatherer' ${ }^{(36)}$. Skeptics of evolutionary medicine often raise the intuitive criticism that the human ancestor had a very short life expectancy compared with contemporary individuals $^{(35)}$. Consequently, they argue, there was no selection pressure on longevity or healthy ageing', since there were virtually no old people, while the few individuals reaching old (for example, postmenopausal) age provided no evolutionary benefit to younger individuals who were still able to reproduce. The counterargument is multilevelled.

\section{Arguments and counterarguments in evolutionary health promotion}

It needs to be emphasised that evolutionary medicine predicts no further increase in life expectancy, but rather a decrease in the numbers in deteriorating health at the end of the life cycle. It has been estimated that the complete elimination of nine leading risk factors in chronic degenerative diseases would increase life expectancy at birth by only 4 years, since these diseases only affect late-life mortality ${ }^{(37)}$. Second, the increased life expectancy at present originates mostly from the greatly diminished influence of some unfavourable conditions of existence, including (childhood) infections, famine, homicide and tribal wars ${ }^{(34,38)}$ secondary to the high levels of medical sciences and continuing civilisation. Thus, to achieve the average life expectancy of 40 years in a present-day hunter-gatherer society, for every child that does not survive beyond 1 year of age, another should reach the age of 80 years. In fact, about $20 \%$ of modern hunter-gatherers reach at least the age of 60 years ${ }^{(39-41)}$. In other words, the popular argument that very few individuals in these societies live past 50 years $^{(35)}$ is unsupported by ethnographic data. The third, often raised, argument is that due to the higher life expectancy in present-day humans, it is invalid to compare the mortality figures for cancer and degenerative disease of present-day hunter-gatherers (with low life expectancies) with those of Western populations (with a life expectancy of 80 years). However, early biomarkers of degenerative diseases such as obesity, high blood pressure, atherosclerosis and insulin resistance are also less common in younger, age-matched, members of present hunter-gatherer compared with members of affluent societies ${ }^{(9,42)}$, while measurements indicative for 'good health' such as muscular strength and aerobic power are more favourable in the former ${ }^{(43)}$. Moreover, even the oldest individuals in hunter-gatherer societies appear virtually free from chronic degenerative diseases ${ }^{(44-46)}$. A fourth counterargument against the assumption that our human ancestors before the Agricultural Revolution died at a young age derives from archaeological records. After the transition from hunting and gathering to farming about $10 \mathrm{Kya}$, life expectancy dropped from about 40 years (as it is in recently studied hunter-gatherers, but also was among students of the Harvard College Class born in $1880^{(47)}$ ) to about 20 years ${ }^{(48-50)}$. This seemingly evolutionary disadvantage, secondary to a decrease in nutritional quality, is substantiated by a decrease in general health that has become noticeable from a decrease in final height, while skeletal markers of infection and nutritional stress became more common in archaeological finds ${ }^{(49-52)}$. These setbacks were eliminated by a net increase in population growth, secondary to an increased productivity per land area that resulted in more energy intake per capita. Life expectancy remained stable throughout the Neolithic until the late 18th century, seldom exceeding 25 years in 'civilised' nations ${ }^{(35)}$. From this time, improvements in hygiene, food production and manufacturing, energy generation, per capita income, shelter, transportation, clothing and energy intakes substantiated an increase to and beyond the life expectancy that prevailed before the onset of the Agricultural Revolution. Greater energy availability enhanced, for example, the energy requirements of the immune system and for 
reproduction, both improving longevity ${ }^{(35,53)}$. Importantly, it was concluded that medical treatments had little impact on mortality reduction, while public health achievements (sanitation, food and water hygiene, quarantine and immunisations) have critically improved life expectancy. The fifth counterargument is that old people do provide an evolutionary benefit to the younger generations. Male fertility remains largely intact and male provisioning might help in the problem of high female reproductive costs, although the latter is contested ${ }^{(54,55)}$. The benefits of older females have been put forward in the grandmother hypothesis. This hypothesis, in which the presence of older females within a certain group benefits the reproductive success of their offspring, is supported by studies in human hunter-gatherer ${ }^{(56-62)}$ and primate societies ${ }^{(56,60,63)}$. Interestingly, the fitness benefits of grandmothering proved insufficient to fully explain the evolution of increased longevity ${ }^{(62)}$, suggesting that other evolutionary benefits, such as grandfathering, might also be involved in the long reproductive and non-reproductive lifespan of Homo sapiens. A recent analysis supports such benefits for both older males and females, since the presence of post-reproductive women increased the numbers of newborns by $2 \cdot 7 \%$, while $18.4 \%$ of the infants in a polygamous society in rural Africa were sired by males aged 50 years and above ${ }^{(64)}$. In support of the statement that 'nothing in biology makes sense except in the light of evolution' we therefore conclude that, unless proven otherwise, the presence of a substantial proportion of older males and postmenopausal females in hunter-gatherer, in contrast to primate societies, should be considered as proof for the evolutionary benefit that these individuals are to their progeny. Finally, we propose that this assumption would only be convincible if these individuals were reasonably fit, thereby supporting the concept of healthy ageing. Hence, healthy ageing seems both supported by ethnographic data and its benefit to hunter-gatherer societies. Other commonly raised arguments against the genome-environment mismatch hypothesis are the potential genetic changes since the Agricultural Revolution, the heterogeneity of ancestral environments and innate human adaptabilty ${ }^{(35)}$. Counterarguments to these critics have been discussed in great detail elsewhere ${ }^{(35)}$.

In the present review, a multidisciplinary approach is used, including palaeo-environmental reconstruction, comparative anatomy, biogeochemistry, archaeology, anthropology, (patho)physiology and epidemiology, to assess the characteristics of the ecosystem that supported human evolution. Based on this assessment, an approximation is made of the dietary composition that derives from this ecosystem. Finally, the potential benefit of a return to this 'Palaeolithic diet' is discussed and an update is provided for the evidence for the positive health effects of these diets.

\section{Human evolution}

Hominins are defined as members of the taxon Hominini, which comprises modern Homo sapiens and its extinct relatives over the past about 7 million years. The oldestknown hominins (Fig. 1) are Sabelanthropus tchadensis from Chad (about $7 \mathrm{Mya}^{(65)}$ ) and Orrorin tugenensis from Kenya (about 6-5.7 $\mathrm{Mya}^{(66)}$ ). The next oldest are Ardipithecus kadabba (Ethiopia, about $5.8 \mathrm{Mya}^{(67)}$ ) and A. ramidus (Ethiopia, about $4 \cdot 4 \mathrm{Mya}^{(68)}$ ), Australopithecus anamensis (Kenya, about 4.1-3.9 $\mathrm{Mya}^{(69)}$ ), Au. afarensis (Ethiopia, Tanzania and maybe Kenya, 3.6-3.0 Mya $^{(70,71)}$ ), Au. babrelghazali (Chad, about 3.5 Mya $^{(72)}$ ), Kenyanthropus platyops (Kenya, about 3.5 Mya $^{(73)}$ ), Au. garbi (Ethiopia, about $2.5 \mathrm{Mya}^{(74)}$ ) and $A u$. africanus (South Africa, about 2.9-2.0 Mya ${ }^{(75)}$ ). From these earliest hominins evolved the genera Paranthropus (three known subspecies) and Homo. The earliest species that have been designated Homo are Homo rudolfensis, Homo habilis and Homo erectus sensu lato -including H. ergaster (Eastern Africa, about 2-1.8 Mya): these in turn are the presumed ancestors of Asian $H$. erectus, $H$. heidelbergensis (Africa, Eurasia 0.6-0.3 Mya), H. neanderthalensis (Eurasia, 0.4-0.03 Mya) and H. sapiens (from about $0 \cdot 2$ Mya onwards) ${ }^{(76-78)}$. The recently discovered $H$. floresiensis (0.095-0.013 $\left.\mathrm{Mya}^{(79)}\right)$ and the previously unknown hominins from Denisova Cave (about 0.05-0.03 $\mathrm{Mya}^{(80)}$ ) show that in the recent past several different hominin lines co-existed with modern humans.

Africa is now generally accepted as the ancestral homeland of Homo sapiens ${ }^{(77,81,82)}$. In several subsequent outof-Africa waves ${ }^{(83)}$, hominins of the genus Homo colonised Asia, Australia, Europe and finally the Americas (Fig. 2). Archaic Homo species reached as far as the island of Flores in South-East Asia, East China and Southern Europe (Spain). Homo beidelbergensis remains were found in Africa, Europe and Eastern Asia, while Homo neanderthalensis was restricted to Europe, Western Asia and the Levant. At last, in the later out-of-Africa diaspora starting about $100 \mathrm{Kya}$, Homo sapiens finally reached Australia and the Americas, while probably replacing earlier hominins in Africa, Europe and Asia that had left during the earlier out-of-Africa waves. However, there remains some debate ${ }^{(82,84-86)}$ whether or not the gene pool of archaic hominins contributed to that of modern humans. In the replacement theory, archaic hominins make no contribution to the gene pool of modern man, whereas in the hybridisation theories (either through assimilation or gene flow), newly arriving hominins from the later out-of-Africa wave mixed with archaic predecessors. Current evidence from DNA analyses supports the concept that the gene pool of archaic hominins, notably Neanderthals ${ }^{(87)}$, but also Denisovans $^{(80)}$ contributed to the gene pool of Homo sapiens.

The African cradle of humankind is supported by micro-satellite studies ${ }^{(88)}$ that reveal that within populations the genetic variation decreases in the following 


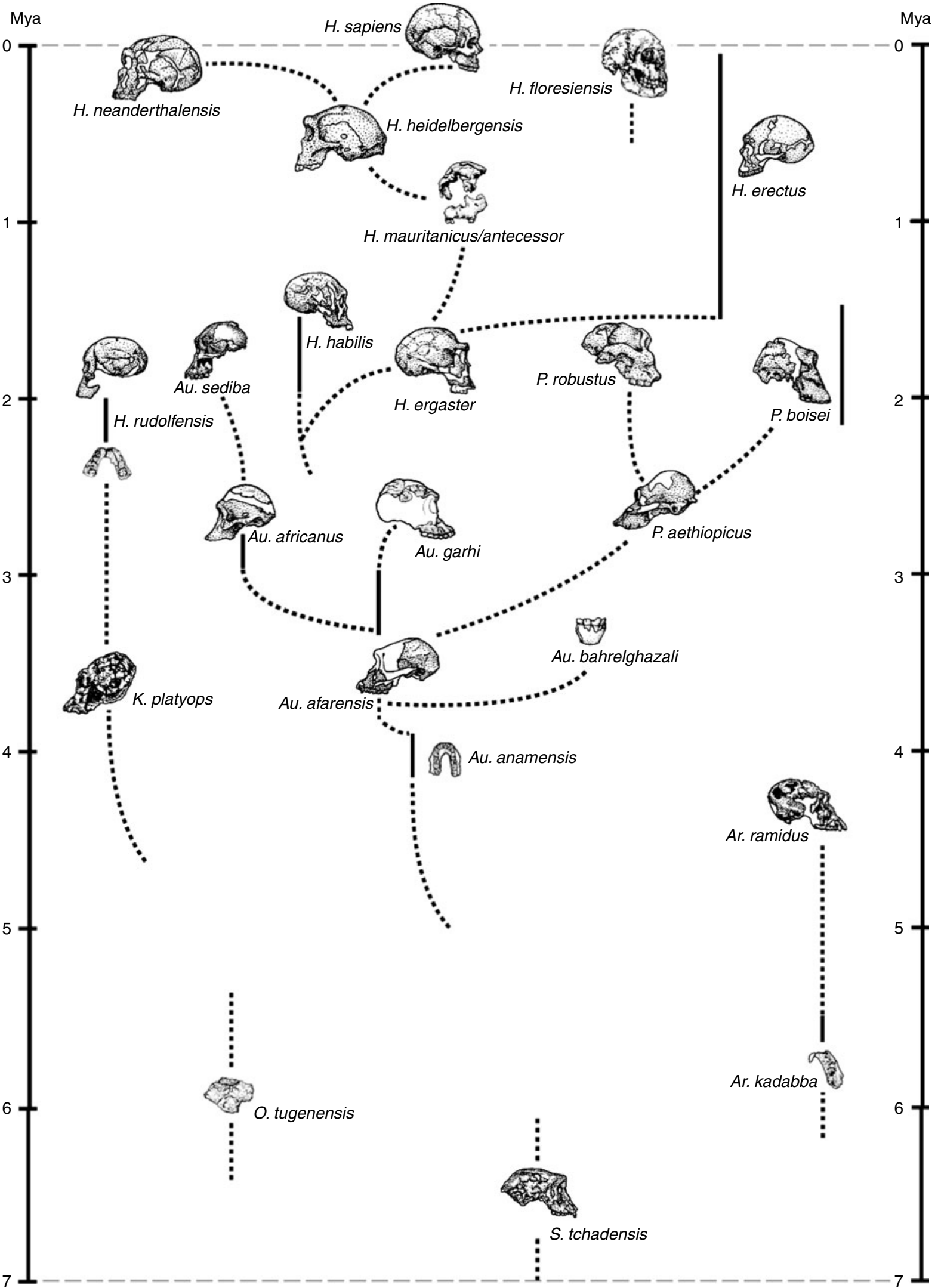

Fig. 1. Scheme of the possible phylogenetic relationships within the family Hominidae. Note that at many time points of evolution, several different hominin species coexisted. Mya, million years ago; H., Homo; Au., Australopithecus; K., Kenyanthropus; P., Paranthropus; Ar., Ardipithecus; O., Orrorin; S., Sahelanthropus. () Ian Tattersall, with permission ${ }^{(76)}$. 


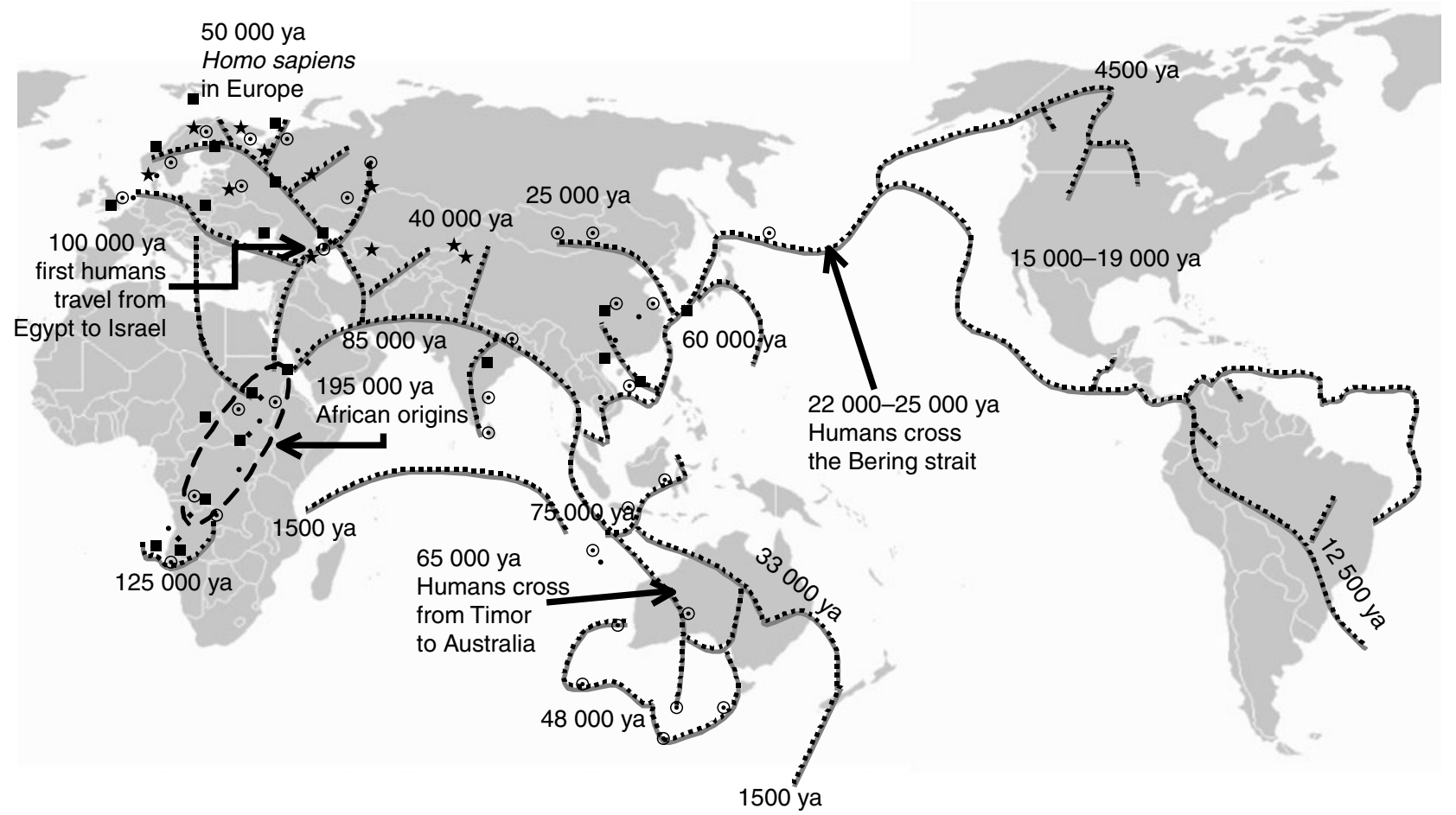

Fig. 2. Coasting out of Africa: following the water in the third out-of-Africa diaspora. Assumed dispersal routes of archaic and anatomically modern man out of

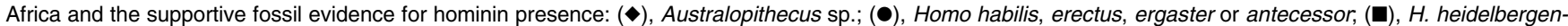
sis; $(\star), H$. neanderthalensis; $(\odot), H$. sapiens. ya, Years ago. Source: National Geographic Society 1988, 1997; adapted from www.handprint.com/LS/ANC/ disp.html and Oppenheimer ${ }^{(83)}$.

order: $\quad$ sub-Saharan Africa $>$ Eurasia $>$ East Asia $>$ Oceania $>$ America, with the hunter-gatherer Hadzabe of Tanzania separated from the Jul'hoansi (previously called !Kung) from Botswana by a genetic distance greater than between any other pair of populations ${ }^{(89)}$, which indicates the chronology of continent inhabitation and points to South or East Africa as the cradle of humankind ${ }^{(89,90)}$. Human evolution was characterised by several large-scale decimations, and it has been estimated that the current world population derives from only 1000 surviving individuals at a certain time point ${ }^{(91)}$. Such bottlenecks ${ }^{(92)}$, characterised by strong population decrease, or where groups of hominids were separated due to global climate changes, volcanic winters or geographic boundaries as mountain ridges or seas, caused gene flow and genetic drift. As a result, different phenotypic races emerged in different geographic regions ${ }^{(88,92)}$. However, differences among these populations contribute only $3-5 \%$ to genetic diversity, while within-population differences among individuals account for $93-95 \%$ of genetic variation ${ }^{(93)}$. In other words, genetically we belong to one species that originally evolved in Africa and that for the great majority genetically still resides in the Palaeolithic era. Most of the current interindividual genetic differences were already existent when Homo sapiens emerged, some $200 \mathrm{Kya}^{(78)}$. Bipedalism, hairlessness, speech and the ability to store fat differentiate humans from the closest relatives, the primates, but it is the uniquely large brain, which allowed for symbolic consciousness and pose 'what-if' questions, that finally made humanity ${ }^{(76)}$.

\section{Changing habitat and increasing brain size}

It is assumed that during the early stages of human evolution early hominins introduced more animal food into their diets, at the expense of plant foods ${ }^{(94,95)}$. Subsequent hominins further increased the amount of animal food and consequently the energy density and (micro)nutrient content of their diet, i.e. the dietary quality. While increasing their dietary intake from animal food, early hominins grew taller and increased their brain mass relative to body mass (encephalisation quotient; EQ). Brain mass in primates relates to the number of neurons ${ }^{(96)}$ and global cognition $^{(97)}$, while the human cortex also has more cycles of cell division compared with other primates ${ }^{(98)}$ During hominin evolution the first significant increase in EQ occurred about 2 Mya (Table 1). From about 2 Mya to 200 Kya the human ancestors tripled their brain size from Australopithecus species with an EQ of 1.23-1.92 to an EQ of $1 \cdot 41-4.26$ for the genus Homo ${ }^{(99,100)}$. The increase in brain size and the number of neurons differentiate Homo from their closest primate relatives. However, a large brain requires an adaptation or an exaptation to accommodate it, and notably sufficient intake of so-called 'brain-selective nutrients' ${ }^{\text {(100,101) }}$ to build and conserve it. 
Table 1. The development of brain weight relative to body dimensions*

\begin{tabular}{lccc}
\hline Species & Brain weight (g) & Brain:body ratio (\%) & Relative EQ† \\
\hline Gorilla gorilla & 500 & 0.3 & 25 \\
Pongo pygmaeus & 400 & 0.5 & 32 \\
Pan troglodytes & 400 & 0.9 & 42 \\
Australopithecus afarensis & 455 & $1 \cdot 7$ & 41 \\
Australopithecus africanus & 450 & $1 \cdot 0$ & 44 \\
Paranthropus aethiopicus & 405 & $1 \cdot 1$ & 44 \\
Paranthropus boisei & 510 & 0.9 & 46 \\
Paranthropus robustus & 520 & $1 \cdot 1$ & 50 \\
Homo rudolfensis & 750 & $1 \cdot 7$ & 59 \\
Homo habilis & 600 & $1 \cdot 7$ & 57 \\
Homo ergaster & 855 & - & 63 \\
Homo erectus & 863 & $1 \cdot 6$ & 74 \\
Homo heidelbergensis & 1200 & 1.8 & 75 \\
Homo neanderthalensis & 1450 & 1.9 & 102 \\
Homo sapiens (Cro-Magnon) & 1490 & 2.4 & 100 \\
Modern Homo sapiens & 1360 & 2.3 & \\
\hline EQ, encephalisation quotient. & & &
\end{tabular}

\section{Buiding a big brain}

Compared with other primates, humans have an extraordinarily large brain ${ }^{(102,103)}$. To understand the expansion of the human brain during evolution, it is important to comprehend its composition and its biochemistry. Brain tissue has a unique profile of long-chain PUFA (LCP) ${ }^{(99)}$. Comparison of the brain ethanolamine phosphoglycerols of forty-two studied animal species shows an almost identical LCP pattern, independent of the grade of encephalisation, containing approximately equal proportions of arachidonic acid (AA) and DHA. Consequently, for normal neuronal function, mammalian brain tissue appears to have an invariant structural requirement for both AA and DHA. This shows that both these fatty acids are important building blocks for building a big brain and for encephalisation. The weight of a newborn human brain is about $340 \mathrm{~g}^{(104)}$ and it contains about $9 \mathrm{~g} \mathrm{lipid}^{(105)}$; the brain of a 10-month-old infant is $850 \mathrm{~g}$ and contains $52 \mathrm{~g}$ lipid. At 3 years, the brain is $1100 \mathrm{~g}$ and contains $130 \mathrm{~g}$ lipid. Thus, the major part of the human brain spurt occurs postnatally ${ }^{(106)}$, implying that especially the newborn infant has high demands for AA and DHA.

Toothed whales (brain weight $9000 \mathrm{~g}$ ) and African elephants $(4200 \mathrm{~g}$ ) have brains much larger than humans, but they have lower cognitive abilities and a lower $\mathrm{EQ}^{(107)}$. These observations substantiate an EQ-centred approach to explain variation in cognition between species. Recent analyses, however, have shown remarkable differences between primate and non-primate brains; a primate brain contains many more neurons than a nonprimate brain of similar size ${ }^{(96,108,109)}$ and the absolute number of neurons, rather than body relative to brain ratio (EQ), best predicts cognitive ability ${ }^{(97)}$, although it still needs to be determined whether humans have the largest number of brain neurons among all mammals.
From this new neuron-centred view, there seems to be nothing special about the human compared with the primate brain, except for its size ${ }^{(96)}$, which basically determines both the number of neurons and nonneurons ${ }^{(110,111)}$. Detailed comparisons of human and primate brains have revealed other differences, such as different levels of gene expression ${ }^{(112-114)}$, secondary to chromosomal rearrangements ${ }^{(115)}$, differences in the relative extent of the neocortical areas ${ }^{(96,116)}$, the distribution of cell types ${ }^{(117)}$ and the decrease of brain structure volumes with increasing age in man in contrast to chimpanzees ${ }^{(118,119)}$. The best predictor of cognitive ability in humans compared with non-primates, however, still needs to be established, but rather than EQ or brain size, the absolute number of neurons seems a prudent candidate ${ }^{(97,108)}$, since there is no clear relationship between neuron number and the absolute brain size among the different animal species ${ }^{(96,108,109)}$.

In contrast to intuitive belief, growing a large brain and a large skull to accommodate it is less difficult to achieve than it seems at first glance. It was recently shown that different levels of expression of a single gene might have resulted in the markedly different beak shapes and lengths of Darwin's finches. Experimental overexpression of the calmodulin gene in chicken embryos resulted in a significant increase in the length of their beaks ${ }^{(120,121)}$. These experiments suggest that small and seemingly insignificant changes can have profound implications for the evolution of anatomical size and shape and thereby provide great potential for explaining the origins of phenotypic variation ${ }^{(122)}$, including increases in brain and skull size. Analogously, many mutations in humans are associated with either microcephaly ${ }^{(123)}$ or macrocephaly ${ }^{(124)}$, while the growth of the skull in hydrocephaly shows that the increased skull size is secondary to the increase of its 
contents, suggesting that brain rather than skull size is the limiting factor here. The evolution of certain genetic variants associated with brain size has accelerated significantly since the divergence from the chimpanzee some 5-6 Mya. A recent variation that occurred 37 Kya has spread more rapidly through the human population than could be explained by genetic drift ${ }^{(125-128)}$, suggesting that it conferred evolutionary advantage.

The anatomical and metabolic changes encoded in the genome (see 'Comparative anatomy') might have provided hominins with the anatomical and energetic opportunity to, over a period of several million years, steadily increase their brain size, but these mutations per se did not fulfil the nutrient requirements for brain expansion ${ }^{(101,129-131)}$. The underlying small number of mutations should rather have been accompanied, and most probably have been preceded, by increased availability of 'brain-specific nutrients' such as LCP for their ultimate conservation through the process of mutation and selection, which basically underlines both Darwin's concept of the crucial importance of 'the conditions of existence' and the secondary role of mutation. An example may come from current knowledge on the sources of AA and DHA. In humans, both AA and DHA can be synthesised from their precursor essential fatty acids $\alpha$-linolenic acid (ALA) and linoleic acid (LA) (Fig. 3), respectively. ALA and LA are present in various natural food resources. ALA is predominantly found in plant foods, while LA is mainly found in vegetable oils such as sunflower-seed oil. Both AA and DHA may derive from their synthesis from abundantly consumed

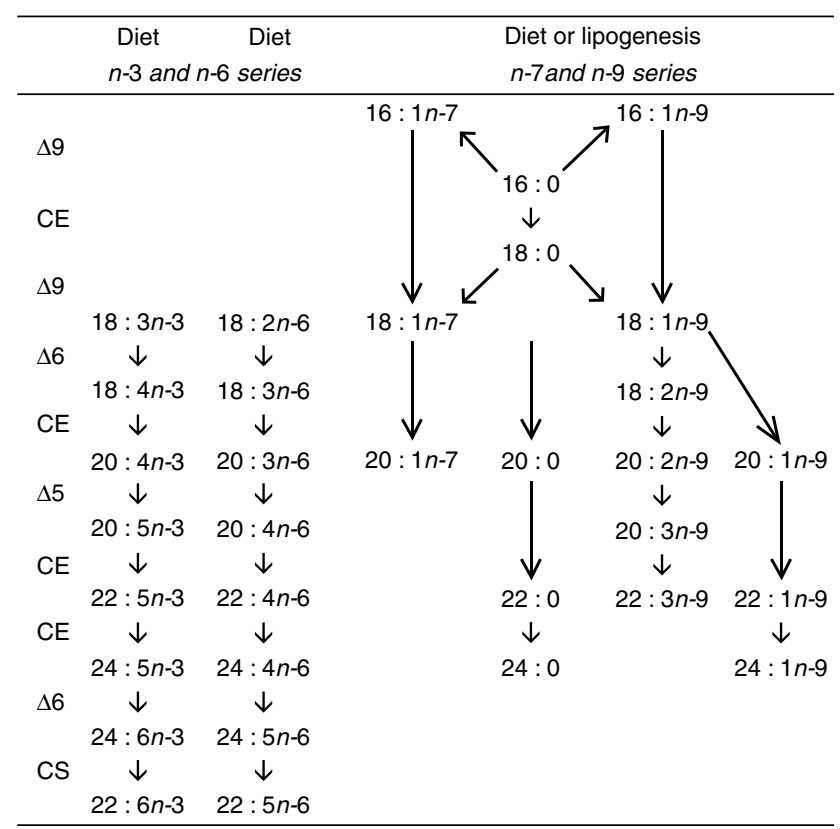

Fig. 3. Metabolism of the parent essential fatty acids and endogenously synthesised fatty acids. $\Delta 9, \Delta 9$-Desaturase; CE, chain elongation; $\Delta 6$, $\Delta 6$-desaturase; $\Delta 5, \Delta 5$-desaturase; CS, chain shortening through peroxisomal $\beta$-oxidation. $18: 3 n-3, \alpha$-linolenic acid; $18: 2 n-6$, linoleic acid; $18: 1 n-9$, oleic acid; $20: 5 n-3$, EPA; $20: 4 n-6$, arachidonic acid; $20: 3 n-9$, mead acid; $22: 6 n-3$, DHA. precursor fatty acids ALA and LA, but in humans and especially neonates, these synthetic activities are insufficient to cope with metabolic demands ${ }^{(132)}$. Consequently both these LCP, but especially those of the $n$ - 3 series, need to be present in sufficient quantities in our diet. It is still under debate what dietary resource(s) provided the LCP that enabled us to grow a large brain ${ }^{(101,133-137)}$.

\section{The probability of hunting on the savanna}

It has been a longstanding paradigm in palaeoanthopology that early human evolution occurred in a dry and open savanna environment ${ }^{(138-140)}$. Recent studies from the Afar basin ${ }^{(68,141)}$, although recently contested ${ }^{(142-144)}$, indicated that the habitat of Ardipithecus ramidus at about 4.4 Mya was characterised not by savanna but by woodland to grassy woodland conditions. Human characteristics, such as poor water-drinking capacity, excessive urination and transpiration and poor water retention support the argument that we would be poorly adapted savanna dwellers ${ }^{(140)}$.

A second long-reigning paradigm was 'man the hunter', which was the standard version of human origins advocated for many years. Washburn \& Lancaster ${ }^{(94)}$ referred at most to our most recent antecessors, Homo sapiens and possibly $H$. neanderthalensis, when they claimed that our intellect, interests, emotions and basic social life are evolutionary products of the hunting adaptation. The strongest argument against this hunting paradigm comes from combined studies of past and present-day hunter-gatherer societies indicating that the role of hunting is exaggerated, notably (around the campfire) in hunter-gatherer societies, since the majority of the dietary protein is in reality obtained by women gathering nuts, tubers and small animals ${ }^{(145-147)}$. Cordain et al. ${ }^{(148)}$ showed that only $25-35 \%$ of energy (en\%) of subsistence in worldwide hunter-gatherer communities is derived from hunting, while the remainder is derived from both plant and fished food. Thus, while meat from large game may have been the most valued food, it is highly unlikely that it was the most valuable (nutritionally important) food resource from a dietary perspective ${ }^{(41,149)}$. At present, the niche of early hominins and thus the environment of human evolution, and, most importantly for the present review, the nutritional composition of the early human diet are still heavily debated ${ }^{(150)}$.

\section{Reconstruction of our ancient diet}

In the next sections we will discuss various views on (changes in) the hominin ecological niche that over time shaped the human genome to what it currently is.

\section{Palaeo-environments}

Sahelanthropus, Orrorin and Ardipithecus. In the late Miocene (up to $5.3 \mathrm{Mya}$ ), the African continent became 
more arid, which resulted in fragmentation of the (sub)tropical forests and the appearance of more open environments ${ }^{(151)}$. The widespread dispersal of some of the earliest hominins such as Sabelanthropus ${ }^{(65,152)}$, and Australopithecus bahrelghazali from Chad, might be explained by the presence of the relatively low-lying humid EastWest corridor constituted by the remnants of the Cretaceous Central African and Sudan Rifts between Western and Eastern Africa ${ }^{(153,154)}$. The reconstructed environment of Sabelanthropus (about 7 Mya) suggests a mosaic of gallery forest at the edge of a deep, well-oxygenated lake, swampy and vegetated areas, and extensive grasslands ${ }^{(155)}$. Since there is no indication of carnivore modification or fluvial transport of its bones, Sabelanthropus chadensis probably lived in this area ${ }^{(156)}$. The palaeo-environment of Orrorin (about 6 Mya) was probably characterised by open woodland, with dense stands of trees in the vicinity and possibly fringing the lake margin and/or streams that drained into the lake ${ }^{(157)}$. Ardipithecus kadabba (5.6 Mya) remains are associated with wet and closed, grassy woodland and forest habitats around lake or river margins $^{(158)}$. Ardipithicus ramidus (4.4 Mya) lived in or near a groundwater-supported grassy woodland to forest $^{(159)}$. Additionally, the abundance of fossilised shallow-water aquatic species such as catfish, barbus, cichlidae and crocodiles additionally suggests an episodically present flood-plain environment ${ }^{(159)}$.

Early Australopithecus species. Australopithecus anamensis appeared at about 4.2 Mya and its environment was characterised by a mix of wetlands and terrestrial environments, such as lacustrine and fluvial floodplains, woodland and gallery forest ${ }^{(156,160-163)}$. The later Australopithecus afarensis survived in a variety of habitats ${ }^{(164)}$, but apparently thrived better in the more wooded and humid conditions in the Afar basin than in the relatively dry Laetoli area ${ }^{(165)}$. Stewart ${ }^{(156)}$ pointed out that in Africa the only environmental constant in hominin sites throughout the period from 3.4 to 2.9 Mya was a wetlands habitat, characterised by aquatic herbaceous vegetations around lakes and rivers, with large populations of wetland fauna such as reduncines and hippopotami. Hence, these wetlands could have been refuge for early hominins throughout an extensive period of human evolution.

Paranthropus, late Australopithecus and Homo species. About 2.9-2.5 Mya tectonic and global climatic changes made Africa cooler and drier ${ }^{(166-169)}$. The great wet forests of middle Africa retreated and made place for more savanna grasslands. It is around this time, from about $2 \cdot 6$ Mya onwards, that the first traces of the new hominin genus Homo appeared in the archaeological record ${ }^{(140)}$. It has been suggested that alternating wet and dry periods after $2 \cdot 7$ Mya could have isolated hominin populations around sources of potable water, while forcing them to the extremes of their conditions of existence ${ }^{(156)}$ and thus facilitating specialisation ${ }^{(170)}$, either by adaptation or exaptation. Compared with Australopithecus, Paranthropus existed in slightly more open habitats, including wetlands and grasslands, but also in woodland and bushland areas. The habitats of Homo species seem similar to those utilised by Paranthropus species ${ }^{(161)}$, but Homo remains at Olduvai Gorge and Koobi Fora are associated with well-vegetated swamps, lakes and river margins, and (semi-) aquatic fauna ${ }^{(171,172)}$. Only the later Homo species are also found in assemblages that indicate extremely arid and open landscapes such as savanna(161). Also, it has been suggested that hominins and other (aquatic) species dispersed throughout Africa along water systems, while even the last out-of-Africa migration might have occurred via the 'green Sahara' that existed during the last interglacial $(125 \mathrm{Kya})^{(156,173)}$

In conclusion, the palaeo-environmental evidence suggests that early hominins lived in the proximity of water. However, it is frequently argued that bones are preferentially preserved in lake, river or fluvial sediments, making their recovery in any other than an aquatic setting unlikely ${ }^{(174)}$. Alternatively, hominin remains may have been relocated to the water by carnivores ${ }^{(162)}$, including crocodiles. Nevertheless, the combined evidence strongly suggests that early hominins frequented the land-water ecosystem and thus lived there. Joordens et al. ${ }^{(154)}$ proposed, based on comparison with other terrestrial omnivores, that the default assumption should be that hominins living in freshwater or marine coastal ecosystems with catchable aquatic resources could have consumed these aquatic resources ${ }^{(154,175)}$

\section{Comparative anatomy}

The diet of our closest relatives. Field studies on our closest relatives, the extant apes, show that their preferred food items are primarily fruits and/or leaves and stems from terrestrial forests. Lowland gorillas, for example, derive $57 \%$ of their metabolisable energy (en\%) from SCFA derived from colonic fermentation of fibre, $2.5 \mathrm{en} \%$ from fat, 24 en $\%$ from protein and 16 en $\%$ from carbohydrate ${ }^{(176)}$. 'Fallback foods' are consumed when preferred foods are unavailable ${ }^{(177)}$ and are generally composed of herbaceous plants and high-fibre fruits from aquatic and terrestrial environments ${ }^{(156)}$. Like our closest relatives $^{(156,178-181)}$, hominins might have used foods from the aquatic environment as fallback foods, while, although speculative, this niche might eventually have proven favourable with regard to subsequent encephalisation.

Teeth morphology and dental microwear. Comparative anatomy (Fig. 4) of the hominins might confer some information about these fallback and preferred foods of our ancestors. Dental studies of Sabelanthropus (Fig. 1) describe that the teeth had thick enamel ${ }^{(65)}$, similar to orangutans, suggesting that it could eat hard and tough foods ${ }^{(182)}$, such as available from the lakeshore vegetation ${ }^{(156)}$. Ardipithecus ramidus, however, had thin molar enamel and smaller teeth compared with later hominins. This dental morphology is 


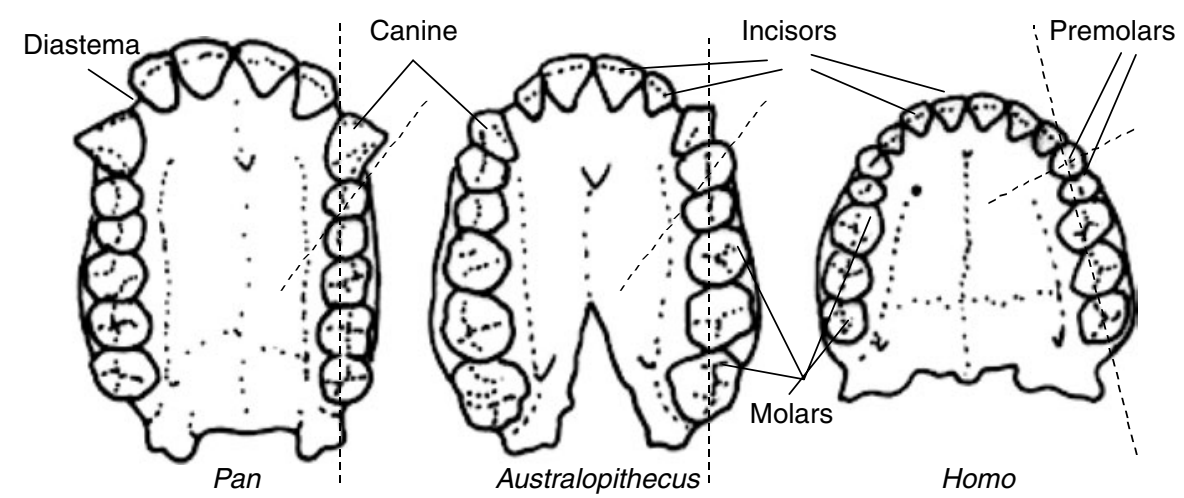

Fig. 4. Lower jaw of a chimpanzee (Pan troglodytes), Australopithecus africanus and Homo sapiens. Note the somewhat human-like shape of the teeth, but apelike axis in the jaw of Australopithecus. (C) Australian Museum.

consistent with a partially terrestrial, omnivorous/frugivorous niche ${ }^{(183)}$. Studies on cranio-dental changes such as tooth size, tooth shape, enamel structure and jaw biomechanics indicate that Australopithecus and Paranthropus had prominent jaws, relatively flat molar teeth, small incisors and thick enamel, suitable for breaking and crushing small hard, brittle foods such as fruits, nuts and underground storage organs ${ }^{(150)}$, but unsuitable for breaking down tough plant foods or tearing meat. Together, this would allow early hominins to eat both hard and soft, abrasive and non-abrasive foods, which suits well for life in a variety of habitats ${ }^{(184)}$.

In addition to studies on teeth morphology, microwear studies are essential. Dental microwear studies analyse tooth-wear, showing evidence for where teeth were actually used for and thus what an animal in reality ate ${ }^{(185)}$. While adaptive morphology will give important clues about what a species was capable of eating, microwear studies reflect what an animal ate during some point in its lifetime. In these studies, 'complexity' is used as an indicator for hard and brittle items, while 'anisotrophy' is an indicator for tough foods ${ }^{(186)}$.

Most primates show either low complexity combined with high anisotrophy, indicative of consumption of tough foods such as leaves, stems and meat, or high complexity with low anisotrophy associated with hard-brittle foods, such as nuts and seeds ${ }^{(150,187)}$. Ardipithecus ramidus's preference for an omnivorous/frugivorous diet was confirmed by microwear studies ${ }^{(183)}$, suggesting a diet of fleshy fruits and soft young leaves ${ }^{(150)}$. Conversely, microwear textures of Australopithicus afarensis and anamensis show striations rather than pits (low complexity and low anisotrophy), i.e. patterns similar to those of grass-eating and folivorous monkeys instead of the predicted diets predominated by hard and brittle foods ${ }^{(187,188)}$. Australopithecus africanus showed microwear patterns that were more anisotropic, suggestive for consumption of tough leaves, grasses and stems ${ }^{(189)}$. Paranthropus robustus, also know as the 'Nutcracker Man', has enormous, flat, thickly enamelled teeth that are combined with a robust cranium, mandible and powerful chewing muscles, suggestive of breaking hard and brittle foods ${ }^{(186)}$. After microwear analysis of its teeth, however, Ungar et al. ${ }^{(150,186)}$ showed that $P$. robustus had low complexity and anisotrophy; thus Paranthropus might only have consumed mechanically challenging items as fallback foods when preferred foods were unavailable. Similarly, microwear studies support the notion that the diet of $P$. boisei contained large quantities of low-quality vegetation, rather than hard objects ${ }^{(190)}$.

Generally, microwear studies confirm earlier dental topography studies ${ }^{(191)}$, which revealed the incorporation of more fracture-resistant foods, i.e. tougher foods as leaves, woody plants, underground storage organs and animal tissues, in the diet of Australopithecus africanus compared with Australopithecus afarensis and for P. robustus compared with Australopithecus africanus ${ }^{(187)}$. Dental topographic analysis suggested that successive Homo species emphasised more on tougher and elastic foods, perhaps including meat ${ }^{(191)}$. The latter suggestion is in line with the optimal foraging theory, which states that humans prefer foods with high energy density over those with low energy density ${ }^{(192,193)}$.

Microwear studies confirmed that early Homo, such as $H$. erectus and $H$. habilis, did not prefer fracture-resistant foods, although some $H$. erectus specimens showed more small pits than $H$. habilis members, suggesting that none of the early Homo specialised on very hard-brittle or tough foods, but rather could consume a varied diet ${ }^{(194)}$ This does not imply that early Homo had very broad diets, but rather that early Homo was adapted to subsist in a range of different environments, providing evolutionary advantage in the climatic fluctuations and the mosaic of habitats in Africa during the late Pliocene ${ }^{(195)}$. A study on dental microwear of 300000 -year-old $H$. heidelbergensis teeth from Sima de los Huesos in Spain showed striation patterns that indicated a highly abrasive diet, with substantial dependence on poorly processed plant foods such as roots, stems and seeds ${ }^{(196)}$. Lalueza et al. ${ }^{(197)}$ compared teeth of very recent hunter-gatherers (Inuit, Fueguians, Bushmen, Aborigines, Andamanese, Indians, Veddahs, Tasmanians, Laps and Hindus) with Middle and Upper Pleistocene fossils. Their results indicate that some 
Neanderthals resemble carnivorous groups, while archaic $H$. sapiens show a more abrasive diet, partly dependent on vegetable materials.

Overall, remarkably few studies have related microwear patterns to hominin diet for the period between 1.5 Mya and 50 Kya (PS Ungar, personal communication). Studies in more recent hominins, such as from an Upper Palaeolithic site in the Levant (22500-23500 before present; BP) showed a high frequency of long narrow scratches and few small pits, suggesting a tough abrasive diet of aquatic foods rather than a diet with hard foods that needed compressive force ${ }^{(198,199)}$. A study of subsequent local hunter-gatherer (12500-10250 BP) and farmers (10250-7500 BP) living in the Levant showed larger dental pits and wider scratches among the farmers compared with the hunter-gatherers, suggesting that the implementation of agriculture led to a more fractureresistant diet ${ }^{(199)}$.

Gut morphology, energy expenditure and muscularity. Gut morphology studies ${ }^{(200,201)}$ support the introduction of animal foods, at the expense of vegetable foods, in the diet of early Homo. The dominance of the colon $(>45 \%)$ in apes indicates adaptation to a diet rich in bulky plant material, such as plant fibre and woody seeds. In contrast, the proportion of the human gut dominated by the small intestine ( $>56 \%$ ) suggests adaptation to a diet that is highly digestible, indicating a closer structural analogy with carnivores than to folivorous or frugivorous mammals. Importantly, the shorter gut in Homo, as compared with primates, might have had some other advantage. During the evolution from Ardipithecus and Australopithecines to early Homo, the improvement of dietary quality coincided with an increase in height, the size of our brain and its metabolic activity. However, an increase in body size coincides with increased daily energy demands, notably during gestation ${ }^{(202)}$ and lactation ${ }^{(203)}$. It was, for example, calculated that daily energy expenditure for a Homo erectus female is about $66 \%$ higher compared with an Australopithicine female, while being almost $100 \%$ higher in a lactating Homo erectus female compared with a non-lactating, non-pregnant Australopithicine ${ }^{(204)}$. These high energy demands might have been met by increased female fat reserves ${ }^{(205,206)}$, such as demonstrated by the presence of female steatopygia in some traditional human populations, such as the Khoisan of southern Africa.

Apart from the extra energy need for reproduction and increasing height, the human brain of a modern adult uses $20-25$ en\% of the total RMR, while this value is $8-9$ en\% for a primate ${ }^{(207)}$. It has been postulated that the extra energy needs did not derive from a general increase in RMR, but partly from a concomitant reduction of the gastrointestinal tract ${ }^{(208)}$ and a reduction in muscularity ${ }^{(207)}$. These features are combined in the 'expensive tissue hypothesis' of Aiello \& Wheeler ${ }^{(208)}$ that points at the observation that the mass of the human gastrointestinal tract is only $60 \%$ of that expected for a similar-sized primate and that humans are relatively under-muscled compared with other primates ${ }^{(207)}$. Interestingly, the negative relationship between gut and brain size across anthropoid primates ${ }^{\text {(209) }}$ was confirmed in a study with highly encephalised fish ${ }^{(210)}$, whereas it became falsified in mammals ${ }^{(102)}$. Unfortunately, however, the latter study did not include marine mammals ${ }^{(102)}$, while it is questionable whether with respect to brain development humans adhere to general mammalian rules ${ }^{(103)}$. Other adaptations might have saved energy expenditure as well. The short human inter-birth interval ${ }^{(204)}$, compared with inter-birth intervals of 4-8 years in the gorilla, chimpanzee and orangutang ${ }^{(211)}$, reduces the most expensive part of reproduction, i.e. lactation ${ }^{(212,213)}$, while the shift from quadrupedal to bipedal locomotion also reduced daily energy expenditure $^{(214)}$. Together, all of these adaptations allow for an increased daily energy expenditure, including the reallocation of energy to the metabolically active brain, but were only possible after Homo included more energydense foods into its diet. Brain mass in primates is positively related to dietary quality and inversely to body weight ${ }^{(207)}$. Generally, a shift towards more energy-dense foods includes a shift from primarily carbohydrate-rich vegetables to fatand protein-rich animal foods. However, it has also been suggested that a shift from the complex carbohydrates in leafy vegetables towards underground storage organs, such as tubers, might have provided easy-to-digest carbohydrates ${ }^{(200,215)}$ to support a larger hominin body mass.

A phenotypic specialisation on non-preferred resources, without compromising the ability to use preferred resources, is also known as Liem's paradox ${ }^{(216)}$. This paradox is important to keep in mind during attempts to reconstruct the preferred diet from the available evidence. Interestingly, Stewart ${ }^{(156)}$ recently noted that in the case of Paranthropus's phenotype with regard to its fallback food, there is just as much evidence to talk about a 'Nutcracker Man' as there is to talk about a 'Shellcracker Man'. Thus, a phenotypic characterisation needs support from other studies to confirm adaptation to preferred rather than fallback foods. In other words, it should be noted that not all physical characteristics might be taken as unambiguous proof for the preferred diet of early hominins (Liem's paradox). The increasing absolute body size and brain size and the reduction in gut size, however, do indicate a shift from low- to high-dietary-quality foods for more recent hominins.

\section{Biogeochemistry}

Evidence from the strontium:calcium ratio. Based upon the principle 'you are what you eat' ${ }^{\text {(217) }}$ several techniques have been developed to study early hominin diets ${ }^{(218)}$. Trace element studies first started with Sr:Ca ratios, which decrease as an animal moves up the food chain, secondary to the biological discrimination against strontium ${ }^{(219)}$. A first study $^{(220)}$ suggested that Paranthropus robustus (Fig. 1) 
had lower Sr:Ca ratios compared with contemporaneous Papio (baboon) and Procavia (hyrax), suggesting that Paranthropus was not an exclusive herbivore. However, a subsequent study showed that two Homo specimens had a higher Sr:Ca ratio than Paranthropus ${ }^{(221)}$. Since Homo had been assumed to consume more animal foods than Paranthropus and thus have a lower Sr:Ca ratio, these higher Sr:Ca ratios needed explanation. For example, consumption of specific foods with a high Sr:Ca ratio might have increased the ratio in Homo compared with Paranthropus. Foods in the area of research with elevated Sr:Ca ratios were mainly geophytes. These are notably perennial plants with underground food storage organs, such as roots, bulbs, tubers, corms and rhizomes. Consequently, this discrepancy has been attributed to the consumption of underground storage organs by early $\operatorname{Homo}^{(215,221)}$. The use of these underground storage organs may have become necessary from the start of a first period of aridity about $2.8 \mathrm{Mya}$, when forest was replaced by drier woodlands, forcing hominins to search for available resources around water margins ${ }^{(222)}$.

Although promising at first, the use of Sr:Ca ratios was found to suffer from several limitations. For example, a problem is that hominin $\mathrm{Sr}$ :Ca ratios in fossilised bones alter with time ${ }^{(223)}$, a process that is known as diagenesis. This problem can be circumvented by the use of tooth enamel, which is less susceptible to diagenesis than bone $^{(223)}$. Subsequent studies showed that Australopithecus africanus had a higher Sr:Ca ratio in its enamel compared with Paranthropus and contemporaneous browsers, grazers, baboons and carnivores ${ }^{(224-226)}$. The interpretation of these findings, however, remains a subject of debate. For example, a group of brown seaweeds and some aquatic plants discriminate against $\mathrm{Ca}$, resulting in an increase in the $\mathrm{Sr}: \mathrm{Ca}$ ratio, and likewise in the $\mathrm{Sr}: \mathrm{Ca}$ ratio of the fish feeding on them ${ }^{(226,227)}$. Similarly, leaves from trees have lower $\mathrm{Sr}$ :Ca ratios compared with grasses, which becomes subsequently reflected in the $\mathrm{Sr}$ :Ca ratios of browsers and grazers, respectively ${ }^{(228)}$. Thus, it might be argued that the relatively high Sr:Ca ratios in Australopithicines and Homo reflect their consumption of aquatic resources or of animals such as insects or other small animals feeding on grasses. For now, the exploration of especially $\mathrm{Sr}$ :Ca ratios as a dietary proxy method has largely been stalled ${ }^{(229)}$.

Evidence from the barium:calcium ratio. Another trace element ratio that might provide information on the composition of the early hominin diet is the $\mathrm{Ba}$ :Ca ratio, particularly when used in a multiple-element analysis with Sr:Ca and Sr:Ba ratios ${ }^{(224,230)}$. Combined Ba:Ca and Sr:Ba ratios clearly differentiate grazers from browsers and carnivores in both modern and fossil mammals ${ }^{(230)}$. Hominins have a lower $\mathrm{Ba}: \mathrm{Ca}$ and higher $\mathrm{Sr}: \mathrm{Ba}$ ratio compared with grazers and browsers. Paranthropus shows considerable similarity for both ratios with both carnivores and Papionins (baboons), while Australopithecus shows an even higher Sr:Ba ratio. The unusual combination of a high Sr:Ca and low Ba:Ca ratio in hominins (and baboons) has been further observed for some animals such as warthogs and mole rats that make extensive use of underground resources ${ }^{(231)}$. Finally, the high Sr:Ba ratio, as observed in Australopithecus, might derive from the consumption of grass seeds, which have $\mathrm{Sr}$ :Ba ratios three to four times higher than grass straw, while consumption of these grasses is also consistent with stable-isotope evidence (see below) showing that Australopithecus derived a substantial part of its diet from $\mathrm{C}_{4}$ resources. Although not included in any study so far, Sr:Ba ratios in aquatic foods might add to the understanding of the unusual combination of low $\mathrm{Ba}: \mathrm{Ca}$ and high $\mathrm{Sr}$ : Ba ratios.

Evidence from the ${ }^{13} \mathrm{C}:{ }^{12} \mathrm{C}$ ratio. Fractionation studies of carbon isotopes differentiate between different routes of photosynthesis. While most tropical African woody plants from forests (like fruits, leaves, trees, roots, bushes, shrubs and forbs) use the $\mathrm{C}_{3}$ photosynthetic pathway, some South African ${ }^{(232)}$ and East African ${ }^{(233)}$ grasses and sedges use the $\mathrm{C}_{4}$ photosynthetic pathway. $\mathrm{C}_{4}$ plants such as sedges (for example, Cyperus papyrus) typically occur in a mosaic of extensive seasonal and perennial shallow freshwater wetlands that can also be found in savanna and 'bushvelds' receiving summer rainfall ${ }^{(234)}$. The real impact of $\mathrm{C}_{4}$ plants occurred with their spread into Eastern and Southern Africa during the Pliocene ${ }^{(235)}$. Tissues of plants that utilise the $\mathrm{C}_{4}$ pathway have a relatively high content of the stable carbon isotope ${ }^{13} \mathrm{C}$ (about $1.1 \%$ of carbon), since $\mathrm{C}_{3}$ plants discriminate more strongly against ${ }^{13} \mathrm{CO}_{2}$ during photosynthesis. As a result $\mathrm{C}_{3}$ and $\mathrm{C}_{4}$ plants have quite different ${ }^{13} \mathrm{C}:{ }^{12} \mathrm{C}$ ratios in their tissues, as have the herbivorous animals that feed on these plants ${ }^{(228,232)}$ and the carnivores that prey on these herbivores ${ }^{(193,206)}$. Differences are expressed as $\delta^{13} \mathrm{C}$ values $\left(\delta^{13} \mathrm{C}=\right.$ $\left.\left(\left({ }^{13} \mathrm{C}:{ }^{12} \mathrm{C}\right)_{\text {sample }}-\left({ }^{13} \mathrm{C}:{ }^{12} \mathrm{C}\right)_{\text {standard }}\right) \times 1000 /\left({ }^{13} \mathrm{C}:{ }^{12} \mathrm{C}\right)_{\text {standard }}\right)$ in parts per thousand $(\% 0)$ relative to the ${ }^{13} \mathrm{C}:{ }^{12} \mathrm{C}$ ratio in the reference standard (named Pee Dee Belemnite; PDB), i.e. the carbonate obtained from the fossil of a marine Cretaceous cephalopod (Belemnitella americana) which is highly enriched in ${ }^{13} \mathrm{C}\left({ }^{13} \mathrm{C}:{ }^{12} \mathrm{C}\right.$ ratio $\left.=0 \cdot 0112372\right)$. Consequently, most animals have negative $\delta^{13} \mathrm{C}$ values (Fig. 5). The $\delta^{13} \mathrm{C}$ ranges from -35 to $-21 \%$ (mean $-26 \%$ ) in $\mathrm{C}_{3}$ plants and from -14 to $-10 \%$ (mean $-12 \%$ ) in $\mathrm{C}_{4}$ plants ${ }^{(22)}$. Studies that attempted to reconstruct mammalian food webs indicated that carbon is slightly enriched $(1-2 \%)$ with each trophic step ${ }^{(193,206)}$. To facilitate comparison of current and historical animals, $\delta^{13} \mathrm{C}$ analyses are predominantly performed in hard tissues, such as bone collagen and enamel (notably apatite), since these constitute the majority of the fossil record. It was shown that enamel mineral is enriched by about $13 \%$ compared with dietary $\delta^{13} \mathrm{C}^{(238)}$, while collagen is enriched by about $5 \%$ compared with dietary $\delta^{13} \mathrm{C}^{(225)}$. Collagen from terrestrial mammal $\mathrm{C}_{3}$ herbivores shows a value of $-21 \%$ (range -22 to $-14 \%$ ), while in collagen of 


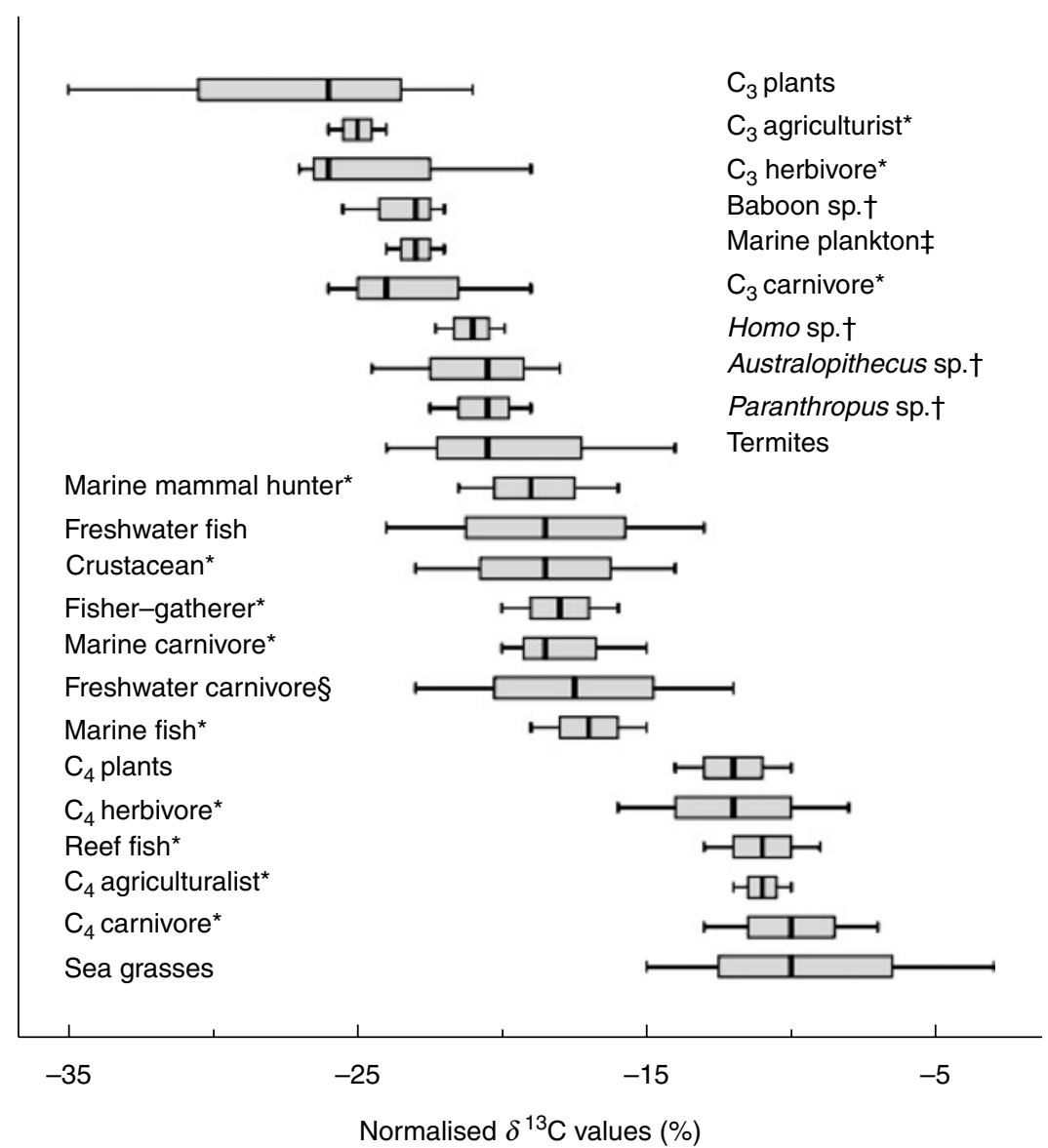

Fig. 5. Normalised collagen $\delta^{13} \mathrm{C}$ values (mean and range; in per thousand (\%)) in plankton, crustaceans, sea grasses, $\mathrm{C}_{3}$ and $\mathrm{C}_{4}$ plants; of marine crustaceans, fish and freshwater fish and their respective carnivores; of terrestrial $\mathrm{C}_{3}$ and $\mathrm{C}_{4}$ herbivores and their carnivores; and of human groups in historic and prehistoric times. * Corrected ${ }^{(229)}$ for collagen $(-5 \% \circ)$. $†$ Corrected ${ }^{(238)}$ for enamel $(-13 \%)$. $\ddagger$ Arbitrary range of $\pm 1 \%$ o due to a lack of data. $\S$ As predicted from other predator-prey relationships and after correction ${ }^{(239)}$ for tropic level $(+1 \% \circ)$. Adapted from Ambrose \& Deniro (228), Sponheimer et al. ${ }^{(231,247)}$, Peters \& Vogel ${ }^{(234)}$, Lee-Thorp et al. ${ }^{(237,244)}$, Kelly ${ }^{(239)}$, Schoeninger \& Deniro ${ }^{(240)}$, Mbabazi et al. ${ }^{(241)}$, Schoeninger et al. ${ }^{(242,246)}$, Sponheimer \& Lee-Thorp ${ }^{(243,248,249)}$ and van der Merwe et al. ${ }^{(245)}$.

$\mathrm{C}_{4}$ herbivores this value is $-7 \%$ ( $(-12$ to $-6 \%$ ). Their respective carnivores show collagen values of $-19 \%$ $(-21$ to $-14 \%)$ and $-5 \%$ ( -8 to $-2 \%$, respectively ${ }^{(225)}$. Marine phytoplankton, which uses the $\mathrm{C}_{3}$ pathway, shows an average value of $-22 \%{ }^{(239)}$. Collagen of marine fish shows a range from $-15 \%$ to $-10 \%$, while the values in collagen of reef fish range from -8 to $-4 \%{ }^{(240)}$. Marine carnivores have, similar to terrestrial carnivores, intermediate values of $-14 \%$, ranging from $-10 \%$ in collagen of sea otters to $-15 \%$ in collagen of the common dolphin ${ }^{(239,240)}$. Thus, also the $\delta^{13} \mathrm{C}$ values of marine carnivores compare well with those of their prey. Finally, $\delta^{13} \mathrm{C}$ values for the muscle of freshwater fish species range from -24 to $-13 \%$, but considerable variation may exist between different lakes ${ }^{(241)}$. Unfortunately, no $\delta^{13} \mathrm{C}$ data are available for terrestrial piscivorous carnivores, but the consistency of the other data suggests that these might be between -24 and $-13 \%$, i.e. comparable with their prey (Fig. 5).

Consistent with the data above, Schoeninger et al. ${ }^{(242)}$ showed that European agriculturalists consuming $\mathrm{C}_{3}$ grasses had much lower $\delta^{13} \mathrm{C}$ values in bone collagen $(-21$ to $-19 \%)$ compared with Mesoamerican agriculturalist consuming $\mathrm{C}_{4}$ maize $(-7$ to $-5 \%$ ), while North American and European fisher-gatherers had intermediate values $(-15$ to $-11 \%$ ). However, bone collagen proved less reliable to study early hominin diets. For that purpose the ${ }^{13} \mathrm{C}:{ }^{12} \mathrm{C}$ ratio is preferably measured in tooth enamel. To compare collagen $\delta^{13} \mathrm{C}$ values with enamel $\delta^{13} \mathrm{C}$ values, an additional $(8 \%)$ correction has to be made. Similar to the clear distinctions between bone collagen of modern grazers, browsers and their carnivores, tooth enamel data from fossilised fauna from South Africa showed similar differences for Plio-Pleistocene $\mathrm{C}_{3}$ feeders $(-11.5 \% 0)$ and $\mathrm{C}_{4}$ feeders (-0.5\%), with Australopithecus, Paranthropus and Homo taking intermediate positions $(-10 \text { to }-4 \%)^{(231,234,237,243)}$, which compared well with the values for contemporaneous felids $(-10$ to $-0.5 \%)^{(231,237,244)}$ (Fig. 5). These results clearly demonstrated that a significant proportion of the diets of the early hominins from Swartkrans, Makapansgat and Sterkfontein derived from $\mathrm{C}_{4}$ resources. Using these data it 
was calculated that South African Paranthropus derived $14-47 \%$ of its diet from $\mathrm{C}_{4}$ sources, compared with 5-64\% in Australopithecus and 20-35\% in Homo ${ }^{\text {(245). }}$

A second study in Olduvai showed that the Tanzanian Paranthropus boisei derived $77-81 \%$ and Homo 23-49\% from its diet from $\mathrm{C}_{4}$ resources ${ }^{(245)}$. The low nutritional value of grasses, and microwear studies (see above) render it unlikely that humans were directly eating grass $^{(231,243)}$. Analogously, the sizeable carnivory of $\mathrm{C}_{4^{-}}$ consuming mammals (such as cane rats, hyraxes or juvenile bovis) was argued to be practically impossible and thus unable to leave a strong $\mathrm{C}_{4}$ signature ${ }^{(243)}$. However, at about 1.8 Mya, there were extensive wetlands in the Olduvai area, where a river from the Ngorongoro mountains entered the area, while at 1.5 Mya the Peninj river produced wetlands near Lake Natron ${ }^{(156)}$. Some researchers investigated the edible plants in a present-day wetland (Okavango Delta) and found that the rhizomes and culms of three species of $\mathrm{C}_{4}$ sedges were edible, the most common one of which is Cyperus papyrus ${ }^{(245)}$. However, it seems unlikely that the $\mathrm{C}_{4}$ signature in all early hominins derived from the consumption of papyrus. It was recently suggested that $P$. robustus and especially $P$. boise $i$ had a diet of primarily $\mathrm{C}_{4}$ resources, most probably grasses or sedges, from savanna or wetland environments, respectively ${ }^{(190)}$. Theoretically, a good source of $\mathrm{C}_{4}$ foods would be a seasonal freshwater wetland with floodplains and perennial marshlands, with an abundance of easy accessible aquatic foods, large aggregations of nesting birds and calving ungulates ${ }^{(234)}$. Consumption of termites could have contributed to the high $\mathrm{C}_{4}$ signature observed in hominin fossils (Fig. 5), but it seems unlikely that termites could explain values as high as $50 \%$ of the diet from $\mathrm{C}_{4}^{(243)}$. Finally, an enamel $\mathrm{C}_{4}$ signature of -10 to $-4 \%$ in hominins, which translates into a soft tissue signature of -23 to $-17 \%$ and a collagen signature of -18 to $-12 \%$ (see above), might also derive from the consumption of small freshwater aquatic animals or fish, since they compare well with the $\delta^{13} \mathrm{C}$ values of -24 to $-13 \%$ for freshwater fish ${ }^{(241)}$ and -18 to $-9 \%$ in collagen of crustaceans and anthropods $^{(240)}$, respectively. Moreover, $\delta^{13} \mathrm{C}$ values for hominins are similar to those reported for marine mammal hunters, freshwater fish, crustaceans, fisher-gatherers, marine and freshwater carnivores and marine fish (Fig. 5).

In agreement with the variability selection hypothesis of Potts ${ }^{(170)}$, which states that large disparities in environmental conditions were responsible for important episodes of adaptive evolution, the wide range in $\delta^{13} \mathrm{C}$ values in particularly Australopithecus suggests that early hominins utilised a wide range of dietary sources, including $\mathrm{C}_{4}$ resources. This contrasts with chimpanzees, which, even in the most arid and open areas of their range, are known to consume negligible amounts of $\mathrm{C}_{4}$ resources, despite their local abundancy. Consequently, chimpanzees show very little variability in their $\delta^{13} \mathrm{C}$ carbon signature ${ }^{(246,247)}$. This underscores that even if contemporaneous chimpanzees and early hominins inhabited similar habitats, hominins had broadened their dietary range sufficiently to survive in habitats uninhabitable by chimpanzees. The latter assumption provides an interesting perspective on the recent data, which suggest that $\mathrm{C}_{4}$ foods were absent in the diet of Ardipithecus ramidus at 4.4 Mya. Consequently, it has been proposed that the origins of the introduction of $\mathrm{C}_{4}$ foods into the hominin diet lie in the period between 3 and $4 \mathrm{Mya}^{(229)}$.

Limited evidence from the ${ }^{15} \mathrm{~N}:{ }^{14} \mathrm{~N}$ ratio. Another stable-isotope ratio that has received considerable attention is the $\mathrm{N}$ isotope $\left({ }^{15} \mathrm{~N}:{ }^{14} \mathrm{~N}\right)$ ratio. A number of food web studies have shown that each step in the food chain is accompanied by 3-4\% enrichment in $\delta^{15} \mathrm{~N}^{(228,239)}$ and that $\delta^{15} \mathrm{~N}$ can therefore be useful as a trophic level indicator. Additionally, animals feeding in marine ecosystems have higher values compared with animals feeding on terrestrial resources ${ }^{(242)}$. For example, North American and European fisher-gatherers and North American marine mammal hunters and salmon fishers had much higher $\delta^{15} \mathrm{~N}$ values $(+13$ to $+20 \%$ ) compared with agriculturalists $(+6$ to $+12 \%$ ). Analyses of phyto- and zooplankton suggest that freshwater organisms have $\delta^{15} \mathrm{~N}$ values intermediate to terrestrial and marine organisms ${ }^{(242)} \cdot \delta^{15} \mathrm{~N}$ values are routinely measured in bone collagen, but it has been shown that good-quality collagen (preserving the original $\delta^{15} \mathrm{~N}$ value) can, and only under favourable conditions, survive up to a maximum of 200000 years ${ }^{(225)}$. This limits $\delta^{15} \mathrm{~N}$ isotopic studies to Late Pleistocene hominins (see below), but with improved technology, future studies using collagen extracted from tooth enamel may expand their application to early hominins ${ }^{(238)}$

Limited evidence from the ${ }^{18} \mathrm{O}:{ }^{16} \mathrm{O}$ ratio. A final isotope that might provide information about an animal's diet and thermophysiological adaptations is the oxygen isotope ratio $\left({ }^{18} \mathrm{O}:{ }^{16} \mathrm{O}\right)$. More energy is needed to vaporise $\mathrm{H}_{2}^{18} \mathrm{O}$ than $\mathrm{H}_{2}^{16} \mathrm{O}$. When ocean water evaporates and during evapotranspiration, i.e. the sum of evaporation and plant transpiration from the earth's land surface to the atmosphere, more of the lighter isotope evaporates as $\mathrm{H}_{2}^{16} \mathrm{O}$. The ensuing ${ }^{18} \mathrm{O}$ enrichment of transpiring leaves results in ${ }^{18} \mathrm{O}$ enrichment in typical browsers such as kudu and giraffe who rely less on free drinking water and derive most of their water from the consumption of the ${ }^{18} \mathrm{O}$-enriched plant water. As the ${ }^{16} \mathrm{O}$-enriched water vapour in clouds moves inland, some of it condenses as rain, during which more of the heavier isotope $\left(\right.$ as $\mathrm{H}_{2}^{18} \mathrm{O}$ ) rains out, making the $\delta^{18} \mathrm{O}$ of coastal rain only slightly less enriched than the original vaporated ocean water, while the $\delta^{18} \mathrm{O}$ of the remaining water vapour that eventually comes down is highly negative (i.e. more ${ }^{18} \mathrm{O}$ depleted). Consequently, river water from rain and melting ice is more $\delta^{18} \mathrm{O}$ negative than seawater. Roots derive their water from meteoric or underground water that is thus relatively depleted from ${ }^{18} \mathrm{O}$ and so become animals that are consuming these roots ${ }^{(248,249)}$. Browsers of leaves 
undergoing evapotranspiration and consumers of roots may thus be expected to have high and low $\delta^{18} \mathrm{O}$ values, respectively.

Australopiths showed lower $\delta^{18} \mathrm{O}$ values compared with Paranthropus, but the meaning of this difference remains uncertain. However, one might argue that Australopithecus preferred less arid conditions compared with Paranthropus or was more dependent on seasonal drinking water ${ }^{(231)}$. Low $\delta^{18} \mathrm{O}$ was additionally found in primates and suids, which might be linked to frugivory, although this is not supported by the higher ${ }^{18} \mathrm{O}$ values found in Ardipithecus ramidus compared with Australopithicines ${ }^{(68,229)}$. Taken together, the use of $\delta^{18} \mathrm{O}$ for exploration of ancient human diets is still in its infancy, but might, especially in combination with other isotope ratios, become more appreciated in the future.

Isotopic data for more recent hominins. It would be of high interest to explore the hominin diet during the last spurt of encephalisation between 1.9 Mya to 100 Kya, when brain size tripled in size to volumes between 1200 and $1490 \mathrm{~cm}^{3}$ for Homo erectus, H. heidelbergensis, $H$. neanderthalensis and modern H. sapiens ${ }^{(100)}$. Isotopic data for this period are, however, absent. Due to the limited preservation of collagen beyond 200000 years, and the near absence of $\mathrm{C}_{4}$ plants in Europe, these answers will have to come from further studies with tooth enamel in Africa and Asia. So far, there is no isotope evidence for the diet of Homo between 1.5 Mya up to 50 Kya (MP Richards, personal communication).

Dietary information from more recent humans comes from data on $\delta^{13} \mathrm{C}$, supplemented with data on $\delta^{15} \mathrm{~N}$ and the ${ }^{13} \mathrm{C}:{ }^{15} \mathrm{~N}$ ratio. The ${ }^{15} \mathrm{~N}$-isotope values of bone collagen $^{(242)}$ for differentiation between aquatic and agricultural diets were additionally verified by the study of the sulfur isotope ratios $\left({ }^{34} \mathrm{~S}:{ }^{32} \mathrm{~S}\right)$, since high intakes of marine organisms also result in higher $\delta^{34} S$ values ${ }^{(250)}$. Combined isotope studies reveal high intakes of animal protein, with substantial proportions derived from freshwater fish by Upper and Middle Palaeolithic (40-12 Kya) humans in Eurasia, indicating that in some populations about $30 \%$ of dietary protein came from marine sources ${ }^{(250-256)}$. In contrast, isotopic evidence indicates that Neanderthals were top-level carnivores that obtained most of their dietary protein from large terrestrial herbivores, although even Neanderthals certainly exploited shellfish such as clams, oysters, mussels and fish on occasion ${ }^{(250-252)}$. At the onset of the Neolithic period (5200 years ago), there was a rapid and complete change from aquatic- to terrestrial-derived proteins among both coastal and inland Britons compared with Mesolithic (9000-5200 years ago) British humans ${ }^{(254)}$, which coincides precisely with the local onset of the Agricultural Revolution in Europe.

Conclusions from isotope studies. The isotope systems that have been studied thus far in hominin bone and teeth provide evidence that early hominins were opportunistic feeders ${ }^{(257)}$. The spread of $\mathrm{C}_{4}$ foods in East Africa, and subsequently in the hominin food chain between 3 and 4 Mya, is in agreement with a niche of early hominins that locates close to the water. This conception is in agreement with the palaeo-environmental evidence. However, many questions still remain unanswered. With regard to the possible niche in the water-land interface, it seems interesting to include aquatic as well as terrestrial piscivorous animals into future studies. The data of combined studies of early hominins and the more recent hominins suggest a gradual increase in dietary animal protein, a part of which may derive from aquatic resources. In the more recent human ancestors, a substantial part of the dietary protein was irrefutably derived from marine resources, and this habit was only abandoned in some cases after the introduction of agriculture at the onset of the Neolithic ${ }^{(254)}$.

\section{Archeology}

The oldest stone tools found so far are dated to $2 \cdot 6$ Mya $^{(258,259)}$ and it has been suggested that these were used for flesh removal and percussion on long bones for marrow access. From this time onward stone tools were apparently used for defleshing and butchering of large animals. However, again there is a pitfall in putting too much emphasis on the association between stone tools and hunting and butchering of large animals as the sole food source of the human ancestors, especially with regard to brain foods such as LCP. As stated by Liem's paradox; the apparently overwhelming evidence for the consumption of bone marrow, or even brain from cracked skulls, by the findings of cut marks on animal bone may not be evidence for the primary food resources of human ancestors, but only for its fallback food. Bones, especially long bones, are also better preserved than vegetable material. Moreover, cut marks on bone are easier ascribed to human utilisation than any nearby found fossilised fish bones or molluscan shells that only seldomly bear cut marks ${ }^{(260,261)}$ and are often not even examined. Hence, while human remains are nearly always found in the vicinity of water and the fossil record of nearby found fish is extensive ${ }^{(74,262)}$, the exploitation of aquatic resources is difficult to relate to early $\operatorname{man}^{(263)}$.

The present review is about the diet that allowed early humans to increase their brain size and thereby become intelligent enough to develop, for example, symbolic thinking and the controlled use of fire. Hunting and/or scavenging is often invoked as an important source of LCP, but, as pointed out by Crawford ${ }^{(2)}$, even in the more recent certainly 'hunting' ancestors 'a [scavenged] small brain was not going to go far among the ladies [and children] even if it was still in an edible condition when they [the male hunters] got it back [from the savanna] ${ }^{,(2)}$, not even in the scenario ${ }^{(264)}$ that we were specialised, as suggested ${ }^{(265)}$, in endurance running. Apart from organ tissue (liver and brain) and bone 
marrow (whether scavenged or hunted), fish, shellfish and other aquatic foods are also mentioned as rich sources of the nutrients involved in brain expansion ${ }^{(99,130,266)}$. Therefore, the question arises whether the archeological evidence for human habitation in the land-water ecosystem only represents facilitated fossilisation or indicates the true ecological niche. The following section will focus on comparable evidence for the concurrent exploitation of aquatic resources.

Living in the water-land ecosystem. Because sea levels have risen up to $150 \mathrm{~m}$ in the past 17000 years, a substantial part of the evidence for the exploitation of aquatic resources is hidden below sea level, if not permanently destroyed by the water ${ }^{(267,268)}$. However, in Kenya, a site in East Turkana provides solid evidence that at about 1.95 Mya hominins enjoyed carcasses of both terrestrial and aquatic animals including turtles, crocodiles and fish, which were associated with Oldowan artifacts ${ }^{(261)}$. More ambiguous evidence for the exploitation of freshwater fish, crocodiles, turtles, amphibians and molluscs by Homo habilis in the Olduvai Gorge in Tanzania goes back as far as $1 \cdot 8-1 \cdot 1 \mathrm{Mya}^{(267,269)}$. Subsequent tentative evidence from the Olduvai Gorge dates the use of similar aquatic resources by Homo erectus to $1 \cdot 1-0 \cdot 8$ Mya ${ }^{(267,269)}$. Also the out-of-Africa diaspora probably took place largely via the coastlines ${ }^{(81)}$, even after the crossing of the Bering Strait into North America ${ }^{(270)}$ (Fig. 2). In Koa Pah Nam, Thailand, 700000 -year-old piles of freshwater oyster shells were associated with Homo erectus ${ }^{(271,272)}$. In Holon, Israel, freshwater turtles, shells and hippopotamus bones were associated with Homo erectus and dated to 500-400 Kya ${ }^{(273)}$. Homo erectus fossils associated with seal remains in Mas del Caves (Lunel-Viel, France) were dated to $400 \mathrm{Kya}^{(274)}$.

The archeological evidence for aquatic resource use increases with the appearance of archaic Homo sapiens ${ }^{(267)}$. Although dominated by land mammal bones, 400000-200000-year-old remains from penguin and cormorants in Duinefontein, South Africa were associated with early Homo ${ }^{(275)}$. Shellfish and possibly fish remains, dated 300-230 Kya, were associated with the French coastal campsite at Terra Amata ${ }^{(276,277)}$, while marine shellfish and associated early human remains, dated 186-127 Kya, were found in Lazaret, France ${ }^{(274)}$. Marean et al. ${ }^{(278)}$ found evidence for the inclusion of marine resources, at $164 \mathrm{Kya}$, in the diet of anatomically modern humans from the Pinnacle Point Caves (South Africa). At the Eritrea Red Sea coast, Middle Stone Age artifacts on a fossil reef support the view that early humans exploited near-shore marine food resources by at least $125 \mathrm{Kya}^{(279)}$. In several North African sites, dated to 40-150 $\mathrm{Kya}^{(267)}$, human remains were associated with shell middens and aquatic resources such as aquatic snails, monk seals, mussels and crabs. Several European sites, dated to 30-125 Kya, are comparable with archeological sites that reveal evidence ranging from thick layers of mussels and large heaps of marine shells in Gibraltar ${ }^{(267)}$ to diverse marine shells in Italy ${ }^{(280)}$, and to a casual description of the presence of marine shells of unknown density in Gruta da Figueira in Portugal ${ }^{(267)}$. Further evidence for the use of shellfish, sea mammals and flightless birds comes from: Klasies River Mouth (South Africa) dated between 130 and $55 \mathrm{Kya}^{(267,281,282)}$; from Boegoeberg, where 130 000-40 000-year-old shell middens and cormorant bones were associated with Homo sapiens ${ }^{(267,283)}$; from Herolds Bay Cave, where 120000-80000-year-old shell middens, shellfish, mussels and otter remains were associated with human hearths ${ }^{(267)}$; from Die Kelders (75-55 Kya), where abundant remains of sea mammals, birds and shellfish were found in cave deposits ${ }^{(267,284)}$; and from Hoedjies Punt (70-60 Kya), Sea Harvest (70-60 Kya) and Blombos Cave (60-50 Kya) for the use of shellfish, sea mammals and fish ${ }^{(267,285)}$. From this period onwards, human settlements are strongly associated with the exploitation of aquatic resources ${ }^{(267,268,282,286-288)}$. Evidence for more sophisticated fishing by use of barbed bone harpoon points dates back to 90-75 Kya in Katanda, Semlike River, Zaire ${ }^{(289,290)}$ and to 70 Kya in South Africa $^{(291)}$. Finally, indications for seafaring are dated to 42-15 Kya ${ }^{(292-294)}$. Possibly, seafaring dates as far back as $800 \mathrm{Kya}$, as indicated by the finding of Homo erectus stone tools at the Indonesian island of Flores, which is located on the other side of a deep sea strait ${ }^{(79,295-299)}$ In general, many archeological sites are found along channels, lake- and seashores ${ }^{(99,266,267,282)}$ and reveal aquatic fauna, such as catfish, crocodile and hippopotamus ${ }^{(300)}$, but its proves difficult to relate their possible utilisation to our early ancestors.

Several events within the time span of the past about 2 million years have been attributed to the increase in brain size and intelligence. The introduction of meat in the hominin diet, which resulted in a higher dietary quality, has been discussed above. Claims for controlled fire in the Olduvai Gorge (Tanzania) and Koobi Fora (Kenya) go as far back as $1.5 \mathrm{Mya}^{(215,301,302)}$. Evidence for cooking is as old as $250 \mathrm{Kya}^{(301)}$, but possibly dates back to 800 $\mathrm{Kya}^{(303)}$, when indications of controlled fire were found to be present. However, recently it has been concluded that solid evidence for systematic use of fire is only found from 400 to 300 Kya onwards ${ }^{(304)}$. Evidence that cooking provided increased dietary quality was recently provided by Wrangham et al. ${ }^{(215)}$. According to archeological evidence, this could only have played an important role since the appearance of Homo sapiens ${ }^{(215,301)}$ and Neanderthals ${ }^{(305)}$. Also, the inclusion of aquatic resources as an attributor to human brain evolution has been suggested $^{(2,99-101,130,266,306-308)}$, but remains a matter of debate (134,135,268,309) $^{2}$

From hunting-gathering to agriculture. The huntergatherer lifestyle continued worldwide for several millions of years and ended quite abruptly with the introduction of agriculture. The first indications for the abandonment 
of the hunter-gatherer lifestyle towards settlement come from a 23000 year-old fisher-hunter-gatherer's camp at the shore of the Sea of Galilee ${ }^{(310,311)}$. The associated return from diets containing substantial amounts of protein (from hunting and gathering) back to substantial amounts of carbohydrates is supported by indications for the ground collecting of wild cereals ${ }^{(312)}$. This was slowly followed by the large-scale utilisation of cereals starting with the onset of the Agricultural Revolution some 10 Kya.

As indicated above (see 'Biogeochemistry'), there is much controversy about the diet of the earliest humans and until now it is often stated that fishing was only introduced until more recently. From an anthropological perspective this might be true, since certain types (for example, deepwater) of fishing require advanced techniques ${ }^{(294)}$. However, from a nutritional point of view, 'fishing' might include anything from collecting sessile shellfish to the seasonal hand capture or clubbing of migrating or spawning fish in very shallow water. Since fresh drinking water is the single most important aquatic resource for humans, hominins probably observed predators and scavengers feeding on aquatic animals. This makes it unlikely that they would not have participated in opportunistic harvesting of the shallow-water flora and fauna, such as molluscs, crabs, sea urchins, barnacles, shrimp, fish, fish roe or spawn, amphibians, reptiles, small mammals, birds or weeds ${ }^{(175,267)}$. There are many indications suggesting that the evolution of early Homo and its development to Homo sapiens did not take place in the 'classical' hot, arid and waterless savanna, but occurred in African ecosystems that were notably located in places where the land meets the water (with the land ecosystem possibly consisting of - depending on rainfall

- wooded grasslands). Compared with terrestrial hunting and/or scavenging in the savanna, food from this landwater ecosystem is relatively easy to obtain and is rich in the aforementioned combination of haem-Fe, iodine, Se, vitamins $\mathrm{A}$ and $\mathrm{D}$, and long-chain $n$-3-fatty acids ${ }^{(100,101,266)}$.

In conclusion, there is ample archeological evidence for a shift from the consumption of plant towards animal foods. Second, although there is an extensive archeological record for aquatic fossils (representing possible food) in the vicinity of human remains, their co-occurence is usually attributed to the preferential conservation of human remains in the vicinity of water. The present review provides support for the notion that the exploitation of these aquatic resources by hominins in coastal areas should be the default assumption, unless proven otherwise $^{(154)}$. For a long time period in hominin evolution, hominins derived large amounts of energy from (terrestrial and aquatic) animal fat and protein. This habit became reversed only by the onset of the Neolithic Revolution in the Middle East starting about 10 Kya.

\section{Anthropology}

The hunter-gatherer diet. The Homo genus has been on earth for at least 2.4 million years ${ }^{(313)}$ and for over $99 \%$ of this period has lived as hunter-gatherers ${ }^{(314)}$. Surprisingly, very little information is available on the macro- and micronutrient compositions of their diet in this extended and important period of human evolution ${ }^{(34,148)}$. Since the onset of agriculture, about $10 \mathrm{Kya}$, agriculturalists and nomadic pastoralists have been expanding at the expense of hunter-gatherers ${ }^{(314)}$, with agricultural densities increasing by a factor of 10-1000 compared with the highest hunter densities. For this reason, present-day huntergatherers are often found in marginal environments, unattractive for crop cultivation or animal husbandry.

In order to study the original hunter-gatherer way of life, it is appropriate to aim at the few hunter-gatherer communities living in the richer environments that bear closer resemblance to those in which the evolution of the genus Homo probably took place. Most studies on hunter-gatherers and their diets are, however, performed by anthropologists ${ }^{(315)}$, whose primary interests are different from those of nutritionists. Anthropologists would, for example, conclude that 'fishing was so unimportant as to be a type of food collection,(316), or consider collecting both small land fauna and shellfish ${ }^{(314)}$ as part of 'gathering', whereas from a nutritional point of view considerable differences exist in energy density, macro- and micronutrient composition between plants, terrestrial and aquatic animal foods.

Hunting v. gathering. Studies on food procurement of present-day hunter-gatherer societies show, in terms of energy gain $v$. expenditure, the advantage of hunting compared with plant foraging ${ }^{(192)}$. Nevertheless, three distinct studies $^{(41,148,314)}$ showed that hunting makes up only about $35 \%$ of the subsistence base for worldwide hunter-gatherers, independent of latitude or environment. However, collection of small land fauna and shellfish was included as gathering in these studies. While gathering evidently played an important role over the whole of human evolution, hunting, although introduced later, coincided with 'a major leap for mankind' and has ever since played the most dominating cultural role. While hunting may have overtaken gathering in cultural importance, gathering continued to play a very important nutritional role, because: (i) gathering still contributes about $65 \%$ to the subsistence base; (ii) many micronutrients derive only from plant sources; (iii) gathering of, for example, shellfish provides a substantial amount of LCP and other nutrients essential for brain development; and (iv) gathering plays an important cultural role since women, children and grandparents can participate ${ }^{(56,57,317)}$.

Contrary to common belief, hunting in present-day hunter-gatherers is still not very successful: the probability for a kill in !Kung bushmen is only $23 \%^{(314)}$ and the subsistence of Hadza, as described by Marlowe ${ }^{(41)}$ and 
Woodburn $^{(145)}$, is composed of $75-80 \%$ of plant foods. Conversely, studies of North American hunting-gathering societies describe the dietary role of shellfish as similar to 'bread and butter', being the staple food ${ }^{(318)}$ in these societies. The anthropological remark ${ }^{(314)}$ that for many studied hunter-gatherer tribes 'fishing was only a type of food collection' also adds to the notion that the collection of aquatic foods might have preceded scavenging and hunting. Collecting aquatic foods is still daily practice in Eastern Africa and picking up, clubbing or spearing stranded aquatic animals seems much easier and safer than either scavenging or hunting game on the Serengeti plains.

We conclude that gathering plays, and most likely always played, the major role in food procurement of humans. Although hunting doubtlessly leaves the most prominent signature in the archaeological record, gathering of vegetables and the collection of animal, notably aquatic, resources (regardless of whether their collection is considered as either hunting or gathering), seems much easier compared with hunting on the hot and arid savanna. We suggest that it seems fair to consider these types of foods as an important part of the human diet, unless proven otherwise ${ }^{(154)}$. Conversely, while hunting might have played a much more important role at higher latitudes, dietary resources in these ecosystems are rich in $n$-3-fatty acids (for example, fatty fish and large aquatic mammals), while the hominin invasion of these biomes occurred only after the development of more developed hunting skills.

\section{(Patho)physiology}

Brain-selective nutrients. Nutrients and other environmental factors are increasingly recognised to influence epigenetic marks ${ }^{(319-323)}$, either directly or indirectly via many bodily sensors. Food from the diverse East African aquatic ecosystems is rich in haem-Fe, iodine, Se, vitamins A and $\mathrm{D}$, and $n-3$ fatty acids from both vegetable origin and fish ${ }^{(101)}$. All of these nutrients seem to act at the crossroad of metabolism and inflammation ${ }^{(24)}$. For example, $\operatorname{PPAR}^{(324,325)}$ are lipid-driven nuclear receptors with key cellular functions in metabolism and inflammation ${ }^{(26)}$. $\mathrm{TR}^{(326)}, \mathrm{VDR}^{(327)}$, RXR and $\mathrm{RAR}^{(328)}$ are other examples of nuclear transcription factors that serve functions as ligand-driven sensors. The iodine- and Se-dependent hormone triiodothyronine $\left(\mathrm{T}_{3}\right)^{(329-331)}$ is a ligand of $\mathrm{TR}^{(326)}$, many fatty acids and their derivatives are ligands of PPAR $^{(332)}$, the vitamin D-derived 1,25-dihydroxyvitamin D hormone is a ligand of the $\mathrm{VDR}^{(333)}$, 9-cis-retinoic acid and the fish oil fatty acid DHA are ligands of $\mathrm{RXR}^{(328)}$, while RAR interacts with vitamin A (retinol) and many of its derivatives such as all-trans-retinoic acid, retinal and retinyl acetate ${ }^{(328)}$. The ligated nuclear transcription factors usually do not support transcription by themselves, but need to homodimerise or heterodimerise notably with
RXR to facilitate gene transcription. Examples of the latter are $\mathrm{TR} / \mathrm{RXR}, \mathrm{PPAR} / \mathrm{RXR}, \mathrm{VDR} / \mathrm{RXR}$ and RAR/RXR. It has become clear that their modes of action illustrate the need of balance between, for example, iodine, Se, fish oil fatty acids and vitamins $\mathrm{A}$ and $\mathrm{D}$, a balance that is notably found in the land-water ecosystem.

Deficiencies of the above 'brain-selective nutrients' are among the most widely encountered in the current world population ${ }^{(101,334)}$. While iodide is added to table salt in many countries, margarines and milk have become popular food products for fortification with vitamins $\mathrm{A}$ and D. After discussing some general health differences between traditionally living individuals and those living in Westernised countries, we focus on the importance of LCP and notably those of the $n$-3-series, as examples of the above-mentioned nutrients that are especially abundant in the land-water ecosystem.

Hunter-gatherer v. 'Western' physiology. There are many differences in health indicators between traditionally living individuals and those living in Western societies. For instance, primary and secondary intervention trials with statins indicate lowest $\mathrm{CHD}$ risk at an LDL-cholesterol of $500-700 \mathrm{mg} / 1(1.3-1.8 \mathrm{mmol} / \mathrm{l})$, which is consistent with levels encountered in primates in the wild and huntergatherer populations with few deaths from CVD $^{(335-339)}$. Another example of the healthy lifestyle of present-day hunter-gatherers comes from the observed 'insulinopenia' or 'impaired insulin secretion' following an oral glucose tolerance test (Fig. 6) in Central African Pygmies and Kalahri Bushmen ${ }^{(340,341)}$, respectively. As opposed to the 'impairments' noted by these authors, it may also be argued that these researchers were actually witnessing an insulin sensitivity that has become sporadic in Western countries as a consequence of the decrease in physical activity and fitness, increase in fat mass and as a result of the quantity and quality of the foods consumed ${ }^{(36,133,342)}$. The current consensus is that 'fat is bad' and especially saturated fats have become associated with CVD $^{(343-345)}$. However, traditional Maasai consumed diets high in protein and fat (milk and meat) and low in carbohydrates ${ }^{(346,347)}$ They had high intakes of saturated fat and cholesterol, showed extensive atherosclerosis with lipid infiltration and fibrous changes, but had very few complicated lesions, and were virtually devoid of $\mathrm{CVD}^{(348)}$. The average total and LDL-cholesterol in these societies was low and did not increase with age ${ }^{(348)}$. Finally, the physical fitness of individuals in such traditional societies, such as the Maasai, is often remarkable ${ }^{(337)}$.

In Kalahari Desert Bushmen and Central African Pygmies, observers could not find any case of high blood pressure and blood pressure did not increase with age $^{(335,349)}$. Dental surveys of Kalahari Bushmen ${ }^{(350)}$ and other hunter-gatherers ${ }^{(49)}$ showed a remarkable absence of caries. The absence was explained by the repetitive annual abstinence of fermentable sugars in their diet, with a consequent inability to build a cariogenic oral 

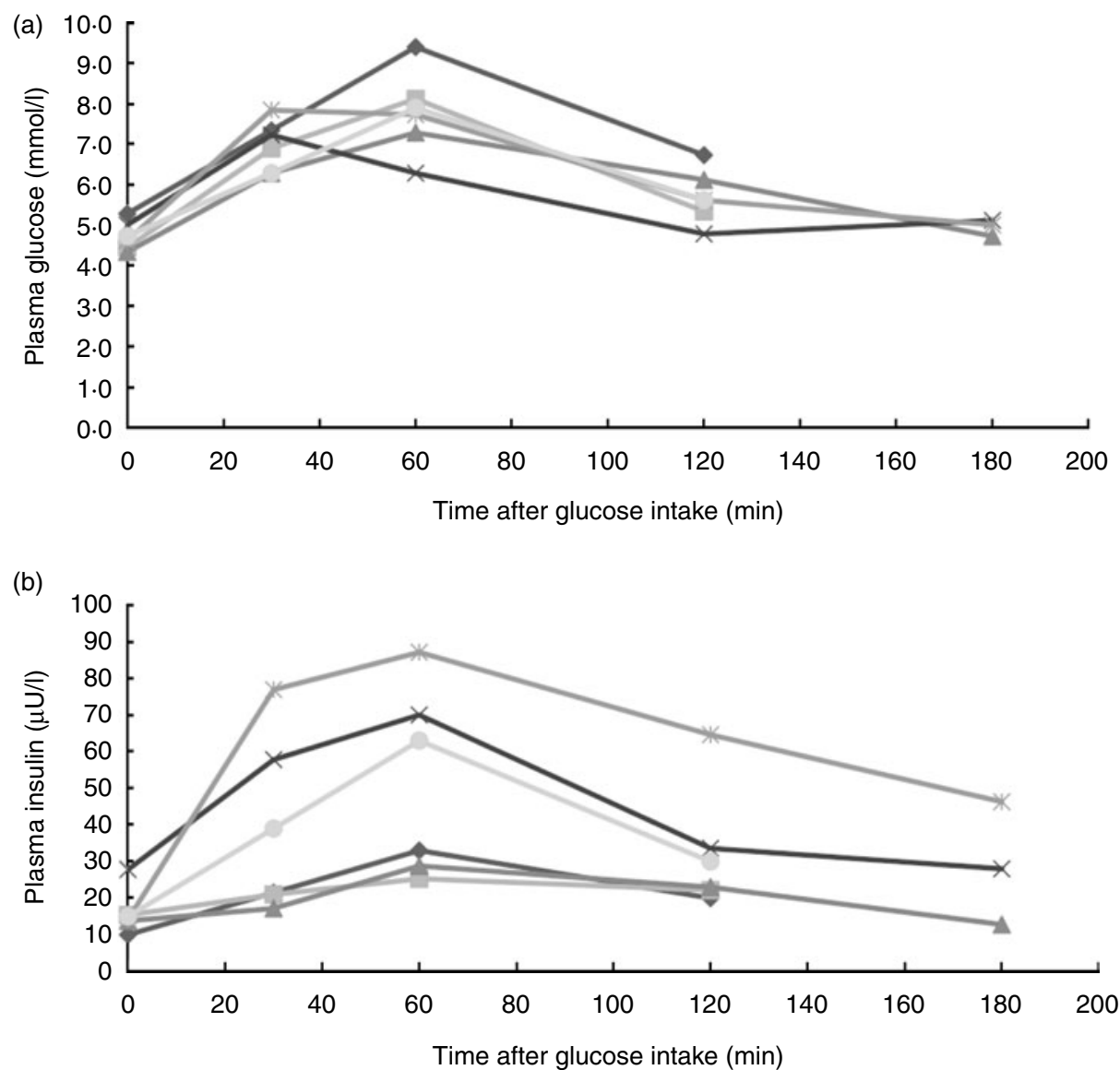

Fig. 6. 'Abnormal' insulin response but normal glucose response after oral glucose tolerance test in African Bushmen and Pygmies, compared with Western controls. (a) Plasma glucose response after an oral glucose load of $50 \mathrm{~g}$ (Bushmen $(\bullet)$ and white controls $(\mathrm{O})$ ) or $100 \mathrm{~g}$ (Pygmy (匚), Pygmy with 2 weeks' daily supplementation of $150 \mathrm{~g}$ carbohydrates before testing $(\mathbf{\Lambda})$, Bantu $(\mathrm{X})$ and American controls $(*))$. Of note is that Bushmen and Pygmies have significantly lower body weights as compared with Bantu and white and American controls (average weight Bushmen/Pygmy males $46 \mathrm{~kg}$, females $38 \mathrm{~kg}$; controls $65 \mathrm{~kg}$ ), while each group received the same unadjusted loading dose of $50 \mathrm{~g}$ or $100 \mathrm{~g}$ glucose. (b) The so-called 'abnormal' insulin response or 'impaired' insulin secretion as observed by the authors in both Bushmen and Pygmies ${ }^{(340,341)}$.

Lactobacillus flora ${ }^{(350)}$. Inhabitants of Kitava (Trobriand Islands, Papua New Guinea) have high intakes (70 en\%) of carbohydrates from yams, high intakes of SFA from coconuts, and a high fish intake ${ }^{(44,45,351)}$. Although both high intakes of carbohydrates and saturated fat have been related to the metabolic syndrome and CVD, these traditional Kitavians do not show symptoms of either the metabolic syndrome and are virtually free from the Western diseases that ensue from it.

Evidence-based medicine as applied to long-chain PUFA in CVD and depression. Despite some compelling examples of the healthy lifestyles of traditional populations, current dietary recommendations derive preferably from randomised clinical trials with single nutrients and preferably hard endpoints ${ }^{(352)}$. This approach clearly oversimplifies the effects of dietary nutrients ${ }^{(353)}$, since neither macronutrients, nor micronutrients, are consumed in isolation and their effects may be the result of a complex web of interactions between all the nutrients present in the biological systems that we consume, such as a banana or a fish.
The current recommendations from many nutritional boards for a daily intake of $450 \mathrm{mg}$ EPA + DHA in adults derive from epidemiological data that demonstrated a negative association of fish consumption with $\mathrm{CHD}^{(354-357)}$ that has subsequently become supported by landmark trials with ALA ${ }^{(358)}$ and fish oil ${ }^{(359-361)}$ in CVD. However, not all trials in CVD have been positive ${ }^{(362)}$. In addition, a negative association was observed for fish consumption and depression $^{(363-365)}$ and for homicide mortality ${ }^{(366)}$. The causality of these relationships was supported by some, but not all, trials with fish oil in depression ${ }^{(367-371)}$, while a recent meta-analysis demonstrated the beneficial effect of EPA supplements with $\geq 60 \%$ EPA of total EPA + DHA in a dose range of $200-2200 \mathrm{mg} / \mathrm{d}$ of EPA in excess of $\mathrm{DHA}^{(372)}$.

The influence of polymorphisms in the genome is increasingly recognised, but seldom interpreted in an evolutionary context. As argued above, most polymorphisms were already amongst us when Homo sapiens emerged, some 200 Kya, while that also holds true for most, if not all, currently identified 'disease susceptibility genes' that are usually abundant but confer low risk ${ }^{(373)}$. 
A loss-of-function mutation in a specific biosynthetic pathway might be an evolutionary advantage if the specific endproduct has been a consistent part of the diet, such as is probably applicable to all vitamins, for example, vitamin $C^{(374,375)}$. Applied to our LCP status, it is nowadays well established that all humans synthesise DHA with difficulty $^{(376,377)}$. Analogously, the recently discovered polymorphisms of fatty acid desaturases 1 (FADS1; also named $\Delta-5$ desaturase) and FADS2 ( $\Delta-6$ desaturase) with lower activities in their conversion of the parent essential fatty acid to LCP suggest that from at least the time of their appearance, the dietary intakes of AA, EPA and DHA have been of sufficient magnitude to balance the LCP $n$-3:LCP $n$-6 ratio $^{(378,379)}$ to maintain good health.

Long-chain PUFA benefits in pregnancy and early life. Another indication for the importance of LCP comes from the higher LCP contents in the fetal circulation compared with the maternal circulation, a process named biomagnification $^{(380-382)}$, which occurs at the expense of the maternal LCP status ${ }^{(383,384)}$. The decreasing maternal $n-3$ LCP status during pregnancy in Western countries is associated with postpartum depression ${ }^{(363,364)}$, although intervention studies with LCP in postpartum depression have been negative so far $^{(370,371,385,386)}$. However, a positive effect was seen for $n$-3 LCP supplementation on depression during pregnancy ${ }^{(387)}$ and it has been advocated to start supplementation earlier in pregnancy and with higher dosages ${ }^{(388)}$

Maternal LCP intakes have also been related to infant health. AA and DHA in premature and low-birth-weight infants correlated positively with anthropometrics, AA to increased birth weight ${ }^{(389)}$ and DHA to prolonged gestation $^{(390-392)}$. Studies with supplementation of DHA during pregnancy yielded, for example, evidence for: (i) the maturation of the brain, visual system and retina of the newborn at 2.5 and 4 months, but not at 6 months $^{(393-397)}$; (ii) increased problem solving at 9 months but no difference in memory ${ }^{(398)}$; and (iii) superior eye-hand coordination at 2.5 years $^{(399)}$ and higher intelligence quotient at 4 years $^{(400)}$ but not at 7 years of age $^{(401)}$. In contrast to the inconclusive human studies, animal studies and combined human and animal studies showed abnormal behaviour together with disturbed cognition at lower brain DHA levels ${ }^{(402)}$. The importance of dietary AA during pregnancy seems less pronounced, but a positive association between umbilical AA and neonatal neurological development ${ }^{(389)}$ and a lower venous AA for those with slightly abnormal neurological development ${ }^{(403)}$ has been shown. A reduced DHA status in the brain is associated with a mildly increased AA status ${ }^{(404)}$, which is in its turn associated with low-grade inflammation ${ }^{(405)}$.

Infant health starts with maternal health; thus dietary recommendations issued for pregnant women indirectly also apply to their infants. The recommendation for adults to consume $450 \mathrm{mg}$ DHA + EPA per d translates into a DHA composition in breast milk of about $0.79 \%{ }^{(406)}$.
However, current recommendations for the composition of infant formulae derive mainly from the range of human milk fatty acid compositions as observed in Western countries, which in their turn derive from women with recorded intakes below the $450 \mathrm{mg}$ recommended daily intake of $\mathrm{EPA}+\mathrm{DHA}^{(407,408)}$

The same paradox holds for other fatty acids in breast milk. For instance, there are few recommendations for the medium-chain SFA (MCSFA) content of human milk. High MCSFA contents in some traditional societies derive from their high intakes of $12: 0$ and 14:0 from coconuts ${ }^{(409)}$. Conversely, the high MCSFA contents in Western populations are primarily influenced by maternal carbohydrate intakes ${ }^{(410)}$, since the mammary gland has the unique ability to convert glucose into MCSFA (6:0-14:0), mainly lauric (12:0) and myristic (14:0) acids. However, women with regular consumption of coconuts have a much higher 12:0:14:0 ratio compared with women with high carbohydrate intakes. Both MCSFA are readily absorbed in the gastrointestinal tract, while antiviral as well as antibacterial properties have been attributed to some MCSFA, but mainly to $12: 0^{(411,412)}$.

The PUFA content of Western milk has increased over the last decades ${ }^{(413,414)}$. While the human milk LA content in the USA increased by at least $250 \%$, its DHA content decreased by almost $50 \%{ }^{(414)}$. The (from an evolutionary point of view) abnormally high LA intake is, despite a lack of evidence ${ }^{(415)}$, advocated for cardiovascular health $^{(416)}$. The resulting high LA status is likely to interfere with both the incorporation of AA and DHA into phospholipids and also inhibits their synthesis from their parent essential fatty acid ${ }^{(417)}$. Major differences are noted in the comparison of the human milk fatty acid compositions of Western mothers compared with some traditional African women $^{(409,418)}$, with unknown consequences for infant health or the occurrence of disease at adult age (i.e. the 'Barker hypothesis') ${ }^{(16,419)}$. It has been proposed that the high concentrations of EPA, DHA as well as AA in human milk, such as described for many fish-consuming societies $^{(409,420,421)}$, might be a more appropriate reflection of the Palaeolithic breast milk composition and may therefore constitute a better reference for infant formulae than do Western human milks ${ }^{(422)}$.

The influence of environment. It is estimated that $70 \%$ of all cases of stroke and colon cancer, $80 \%$ of all CVD and $90 \%$ of all cases of type 2 diabetes mellitus have been caused by lifestyle and could have been prevented by paying more attention to modifiable behaviour factors, including specific aspects of diet, overweight, inactivity and smoking ${ }^{(423)}$. The mismatch between the human diet and the Palaeolithic genome might therefore be responsible for many typically Western diseases. In addition to the evidence from many other disciplines, evidence from (patho)physiology and epidemiology adds to the notion that a great deal of information on healthy diets might derive from the study of the diets of the early human 
ancestors. The metabolic syndrome, characterised by impaired insulin sensitivity, is at the centre of many diseases of civilisation. High intakes of refined carbohydrates as well as low intakes of LCP have been implicated in the development of insulin resistance. As such, low carbohydrate intakes ${ }^{(424,425)}$ and high $\operatorname{LCP}^{(8,34,426,427)}$ intakes by the early human ancestor might explain in part the low incidence of diseases of civilisation in current hunter-gatherer societies. The available evidence from pathophysiology and epidemiology supports the hypothesis that the land-water ecosystem contributed important and indispensable nutrients to evolving hominins.

\section{Dietary reconstruction of the nutrients available in Eastern Africa}

The debate on the ecological niche of human ancestors is unlikely to reach a consensus shortly. The millions of years of human evolution concurred with marked and abrupt climatic changes, which renders a single ecological niche of human ancestry unlikely. However, it is at the same time clear that in a short period of time humans have made tremendous changes in their lifestyle, their diet included, that lie at the basis of the diseases of Western civilisation. This prompted various investigators to reconstruct the possible compositions of diets that could have been consumed by our Palaeolithic ancestors. Their studies are, for example, based on the plausibility that before the Agricultural Revolution, when humans lived as huntergatherers, cereals were no appreciable part of the diet and that wild animals living in the Eastern African savanna and in Eastern African aquatic ecosystems have different fatty acid compositions compared with the domesticated animals that have now become staple foods. For example, the lean savanna animals that inhabit the Eastern African plains have much lower fat contents, and the available fat is much more enriched in $\mathrm{PUFA}^{(428)}$. Similarly, highlatitude (fatty) fish have much higher EPA and DHA contents, but lower AA contents compared with low-latitude (lean) fish from tropical waters ${ }^{(429-432)}$.

Eaton \& Konner ${ }^{(8)}$ where the first to use this approach in reconstructing a Palaeolithic diet; their pioneer study was published in the New England Journal of Medicine in 1985. The authors estimated that late Palaeolithic humans consumed diets containing 35\% meat and $65 \%$ vegetable foods, containing $34 \mathrm{en} \%$ from protein, $45 \mathrm{en} \%$ from carbohydrate and $21 \mathrm{en} \%$ from fat, while the ratio between polyunsaturated and saturated fat equalled 1.41 and their fibre intake amounted to $46 \mathrm{~g} / \mathrm{d}^{(8)}$. These outcomes contrasted with the average American diet at the time, that consisted of 12 en\% protein, 46 en\% carbohydrate and 42 en $\%$ fat, with a polyunsaturated:saturated fat ratio of 0.44 and a fibre intake of $20 \mathrm{~g} / \mathrm{d}$. After 25 years of additional study, Konner \& Eaton confirmed their previous findings by estimating that the Palaeolithic diet provided 25-30 en\% protein, 35-40 en\% carbohydrate and 20-35 en $\% \mathrm{fat}^{(433)}$, while the polyunsaturated:saturated fat ratio was $1 \cdot 40^{(434)}$. Moreover, they concluded that it has become clear since our initial publications that marine, lacustrine, and riverine species were important sources of animal flesh during the evolution of modern Homo sapiens, and may have played

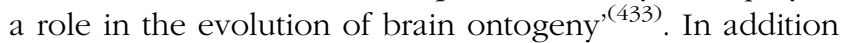
to the earlier studies, they also estimated the vitamin and mineral composition of a Palaeolithic diet, showing higher contents of folate, riboflavin, thiamin, vitamins A and $\mathrm{E}, \mathrm{Ca}, \mathrm{Mg}, \mathrm{P}, \mathrm{Zn}$, and notably ascorbate, vitamin D (sunlight), $\mathrm{Cu}, \mathrm{Fe}, \mathrm{Mn}$ and $\mathrm{K}$, while the Palaeolithic diet contained much lower $\mathrm{Na}$ compared with contemporary US intakes and recommendations ${ }^{(433-435)}$. In a subsequent study they estimated that in different ancient hunting and gathering populations, fatty acid intakes would have ranged from 5.19 to $20.6 \mathrm{~g} \mathrm{LA} / \mathrm{d}, 0.26$ to $4.8 \mathrm{~g} \mathrm{AA} / \mathrm{d}, 3.45$ to $25.2 \mathrm{~g} \mathrm{ALA} / \mathrm{d}$ and 0.03 to $1.52 \mathrm{~g}$ DHA/d, which contrasted with the much higher LA $(22.5 \mathrm{~g} / \mathrm{d})$ and lower ALA $(1.2 \mathrm{~g} / \mathrm{d})$, AA $(0.6 \mathrm{~g} / \mathrm{d})$ and DHA $(0.08 \mathrm{~g} / \mathrm{d})$ intakes as observed in current Western populations ${ }^{(34)}$.

In a meticulous analysis of worldwide hunter-gatherer diets, Cordain et al. ${ }^{(148,436)}$ estimated that the most plausible percentages of total energy from dietary macronutrients would be 19-35 en\% from protein, 22-40 en\% from carbohydrate and 28-58 en\% from fat, which reflects a markedly higher contribution of dietary fat, a similar amount of protein, but a lower contribution of carbohydrates, compared with earlier estimates from Eaton \& Konner ${ }^{(8,434)}$. The main differences were explained by the assumption that, wherever it was ecologically possible, hunter-gatherers would have consumed 45-65\% of total energy from animal foods ${ }^{(148)}$, while in the earlier estimations $^{(8,434)}$ only $35 \%$ derived from animal foods. These higher animal food intakes were explained by their inclusion of both worldwide hunting and fishing hunting-gathering societies into their new calculation models ${ }^{(148)}$, also including mounted and arctic hunters. Those latter possibilities, however, seem insignificant with regard to early human evolution, which explains why they seem to overestimate the amount of the diet that is derived from animal foods. For example, Marlowe ${ }^{(41)}$ estimated that in a warm-climate sample about $53 \%$ of the diet derives from gathering, 26\% from hunting and $21 \%$ from fishing (i.e. about $47 \%$ from hunting).

To subsequently investigate the nutrient compositions of such diets, fish consumption was incorporated as a separate variable to plant and meat consumption in the earlier models, since aquatic and terrestrial animals have markedly different fatty acid compositions. In this most recent analysis $^{(437)}, 12500 \mathrm{~kJ}$ (3000 kcal) Palaeolithic diets were investigated with plant:animal food intake ratios ranging from $70: 30$ to $30: 70$ en\%/en\% under the conditions of four different foraging strategies in which the animal part ranged from exclusive meat consumption including the selective consumption of energy- and LCP-rich fat from bone marrow and brain, respectively ${ }^{(427)}$, to the 
consumption of an entirely aquatic diet in an Eastern African water-land ecosystem ${ }^{(438,439)}$. It was found that that the energy intakes from the macronutrients were: 25-29 en\% (range 8-35) from protein, 39-40 en\% (range 19-48) from carbohydrate and 30-39 en\% (range 20-72) from fat. Dietary LA ranged from 1.7 to $6.2 \mathrm{en} \% / \mathrm{d}$, AA from 1.15 to $10.7 \mathrm{~g} / \mathrm{d}$, ALA from $2 \cdot 1$ to $5.8 \mathrm{en} \% / \mathrm{d}$ and $\mathrm{EPA}+$ DHA intakes from 0.87 to $28.3 \mathrm{~g} / \mathrm{d}^{(437)}$. From these data, despite their wide range in outcomes, it can again be concluded that there are substantial differences with respect to the average composition of the current Western diet, notably because of its higher proportions of carbohydrates and LA, and its much lower protein and ALA and LCP contents. It became also conceivable that ancestors living in the East African water-land ecosystem had daily intakes of gram amounts of EPA + DHA. As such, these $n$ - 3 LCP intakes were comparable with those of the traditionally living Eskimos in Greenland, who because of their low CVD risk ${ }^{(354,355)}$ initiated the current interest in the role of $n-3$ LCP in both primary and secondary prevention of CVD. In addition to these $n-3$ fatty acids, the water-land ecosystem is also a rich source of haem-Fe, iodine, Se and the vitamins $\mathrm{A}$ and $\mathrm{D}^{(101)}$, which have important functions and interactions in gene transcription and metabolism ${ }^{(24,26,440)}$.

\section{Dietary changes since the Agricultural Revolution}

Whatever the specific composition and wide range of early hunter-gatherer diets, the current consensus is that our diet has changed markedly from the time of large-scale utilisation of cereals and animal domestication (i.e. the Agricultural Revolution) starting some 10 Kya. Contrary to earlier belief, the advent of agriculture coincided with an overall decline in nutrition and general health, but at the same time provided an evolutionary advantage since it increased birth rates and thereby promoted net population growth ${ }^{(49,50)}$.

While the decline of nutritional quality and general health started with the onset of the Agricultural Revolution, these processes became even more pronounced with the advent of the Industrial Revolution some 100-200 years ago ${ }^{(9,11,133)}$. Among the many dietary and lifestyle changes (Fig. 7) are: a grossly decreased $n-3: n-6$ fatty acid ratio, the combined high intakes of SFA and carbohydrates ${ }^{(441-443)}$, the introduction of industrially produced trans-fatty acids, reduced intakes of $n-3$ and $n-6$ LCP, reduced exposure to sunlight, low intakes of vitamins $\mathrm{D}$ and $\mathrm{K}$, disbalanced antioxidant status and high intakes of carbohydrates with high glycaemic indices and loads, such as sucrose and industrially produced high-fructose maize $\operatorname{syrup}^{(36,133,444,445)}$. Many of these changes act in concert, which points at the serious limitations of conclusions from contemporary investigations that study the many nutrients in isolation and form the basis of modern nutritional guidelines. An example is the interaction of dietary carbohydrates with SFA ${ }^{(441-443,446)}$.

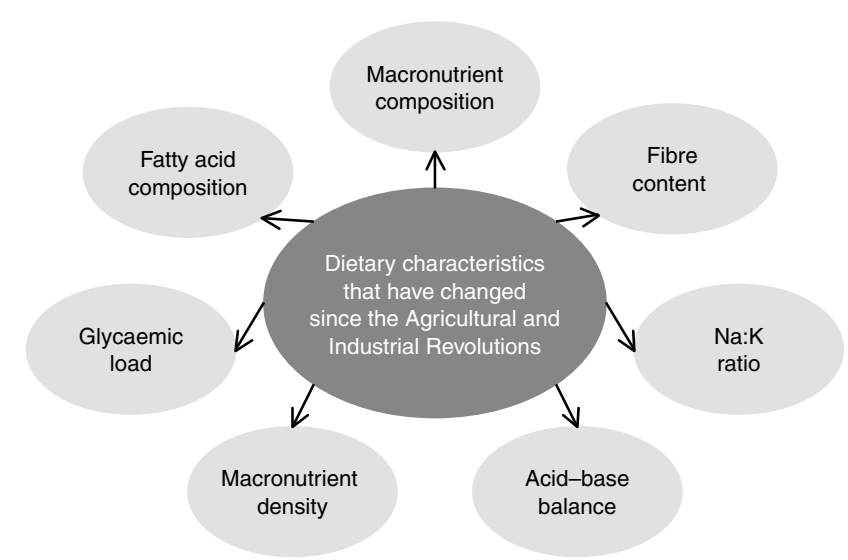

Fig. 7. The seven dietary characteristics that have been changed since the Agricultural and Industrial Revolutions. Adapted from Muskiet ${ }^{(24)}$.

\section{Potential benefits of a Palaeolithic diet}

Evidence for the beneficial effects of Palaeolithic diets may derive from their influence on weight reduction and classical coronary artery disease risk factors. In an uncontrolled study with healthy adults, Osterdahl et al. ${ }^{(447)}$ showed a decrease in weight, BMI and waist circumference after 3 weeks ad libitum consumption of a Palaeolithic-like diet (i.e. $6627 \mathrm{~kJ} / \mathrm{d}(1584 \mathrm{kcal} / \mathrm{d})$; carbohydrate 40, protein 24, fat $36 \mathrm{en} \%)$, compared with their baseline usual diet $(10368 \mathrm{~kJ} / \mathrm{d}(2478 \mathrm{kcal} / \mathrm{d})$; carbohydrate 54 , protein 14 , fat $30 \mathrm{en} \%)$. Additionally, they showed favourable effects on systolic blood pressure and plasminogen activator inhibitor-1. Jönsson et al. ${ }^{(448)}$ performed a cross-over study of $2 \times 3$ months in type 2 diabetic patients receiving a Palaeolithic diet $(6615 \mathrm{~kJ} / \mathrm{d}(1581 \mathrm{kcal} / \mathrm{d})$, carbohydrate 32 , protein 24 , fat $39 \mathrm{en} \%)$ or a diabetes diet $(7858 \mathrm{~kJ} / \mathrm{d}$ $(1878 \mathrm{kcal} / \mathrm{d})$, carbohydrate 42 , protein 20 , fat $34 \mathrm{en} \%)$ They showed a reduction of body weight, BMI and waist circumference and lower $\mathrm{HbA}_{1 \mathrm{c}}$, TAG and diastolic blood pressure, and higher HDL-cholesterol after consumption of the Palaeolithic diet.

In a randomised trial in patients with IHD plus glucose intolerance or type 2 diabetes, Lindeberg et al. ${ }^{(449)}$ showed a reduced energy intake after ad libitum consumption of a Palaeolithic diet $(5623 \mathrm{~kJ} / \mathrm{d}(1344 \mathrm{kcal} / \mathrm{d})$; carbohydrate 40, protein 28, fat $27 \mathrm{en} \%$ ) as compared with an ad libitum Mediterranean-like Consensus diet $(7510 \mathrm{~kJ} / \mathrm{d}(1795 \mathrm{kcal} / \mathrm{d})$; carbohydrate 52 , protein 21 , fat 25 en\%). They also observed a larger improvement in glucose tolerance in the Palaeolithic diet group, independent of decreased waist circumference. The most convincing evidence so far derives from an uncontrolled trial ${ }^{(450)}$ showing that $10 \mathrm{~d}$ consumption of an isoenergetic Palaeolithic diet $(11301 \mathrm{~kJ} / \mathrm{d}(2701 \mathrm{kcal} / \mathrm{d})$; carbohydrate 38 , protein 30, fat $32 \mathrm{en} \%$ ) improved blood pressure, arterial distensibility, insulin sensitivity and total, HDL- and LDLcholesterol in healthy sedentary human subjects, when compared with their baseline usual diet $(9924 \mathrm{~kJ} / \mathrm{d}$ $(2372 \mathrm{kcal} / \mathrm{d})$, carbohydrate 44 , protein 18 , fat $38 \mathrm{en} \%)$. 
Importantly, there were no changes in energy intakes, activity levels and body weight, which indicates that the improved coronary artery disease risk profile was unrelated to weight reduction or other well-known determinants.

\section{Conclusions}

The optimal nutrient combination to support good health can be expected to reflect a certain balance. This balance is present in the foods that were consumed by Palaeolithic and possibly by pre-Palaeolithic ancestors, because it is this balance on which the human genome has evolved. This genome has been shaped by millions of years of evolution, during which it adapted to the conditions of existence, including the diet. There are ample indications from many disciplines that the human ancestors evolved in a water-land interface that provided food from both terrestrial and aquatic resources. For instance, the availability of both $n-3$ and $n-6$ LCP from the aquatic food chain was one of the many factors that provided early humans with the unique combination of brain-selective nutrients for brain growth ${ }^{(2)}$. The recent deviation from this Palaeolithic diet and lifestyle in general might be at the basis of many, if not all, current diseases of civilisation. Detailed studies with respect to the health effects of the diets of these earlier ancestors are therefore warranted.

\section{Acknowledgements}

This research received no specific grant from any funding agency in the public, commercial or not-for-profit sectors.

R. S. K. wrote the initial manuscript. After finishing a first outline, all authors contributed to their specific fields of knowledge, i.e. R. S. K. and F. A. J. M. refined the sections 'Environment, nutrients and their interaction with the genome', 'Evolutionary medicine', 'Arguments and counter arguments in evolutionary health promotion', 'Human evolution', 'Dietary changes since the Agricultural Revolution' and 'Potential benefits of a Palaeolithic diet' and the sub-sections 'Comparative anatomy', 'Biogeochemistry', 'Anthropology', '(Patho)physiology' and 'Dietary reconstruction of the nutrients available in Eastern Africa'; J. C. A. J. refined the section 'The probability of hunting on the savanna' and the sub-sections 'Palaeo-environments' and 'Archeology'.

The authors thank Matt Sponheimer, Mike Richards and Peter Ungar for their willingness to answer their questions.

There are no conflicts of interest.

\section{References}

1. Darwin C (1979) The Illustrated Origin of Species. Ede: Zomer \& Keuning Boeken B.V.

2. Crawford MA (2010) Long-chain polyunsaturated fatty acids in human brain evolution. In Human Brain Evolution. The Influence of Freshwater and Marine Food
Resources, pp. 13-31 [SC Cunnane and KM Stewart, editors]. Hoboken, NJ: Wiley-Blackwell.

3. Knoll AH, Javaux EJ, Hewitt D, et al. (2006) Eukaryotic organisms in Proterozoic oceans. Phil Trans $R$ Soc Lond B Biol Sci 361, 1023-1038.

4. Brocks JJ, Logan GA, Buick R, et al. (1999) Archean molecular fossils and the early rise of eukaryotes. Science $\mathbf{2 8 5}$, 1033-1036.

5. Buick R (2008) When did oxygenic photosynthesis evolve? Phil Trans R Soc Lond B Biol Sci 363, 2731-2743.

6. Holland HD (2006) The oxygenation of the atmosphere and oceans. Phil Trans R Soc B Biol Sci 361, 903-915.

7. Crawford MA \& Marsh DE (1995) Nutrition and Evolution: Food in Evolution and the Future. New Canaan, CT: Keats.

8. Eaton SB \& Konner M (1985) Paleolithic nutrition. A consideration of its nature and current implications. $N$ Engl J Med 312, 283-289.

9. Eaton SB, Konner M \& Shostak M (1988) Stone Agers in the fast lane: chronic degenerative diseases in evolutionary perspective. Am J Med 84, 739-749.

10. Eaton SB, Eaton SB III, Konner MJ, et al. (1996) An evolutionary perspective enhances understanding of human nutritional requirements. J Nutr 126, 1732-1740.

11. Eaton SB \& Cordain L (1997) Evolutionary aspects of diet: old genes, new fuels. Nutritional changes since agriculture. World Rev Nutr Diet 81, 26-37.

12. Egger G \& Dixon J (2009) Should obesity be the main game? Or do we need an environmental makeover to combat the inflammatory and chronic disease epidemics? Obes Rev 10, 237-249.

13. Egger G \& Dixon J (2010) Inflammatory effects of nutritional stimuli: further support for the need for a big picture approach to tackling obesity and chronic disease. Obes Rev 11, $137-149$.

14. Wood B \& Brooks A (1999) Human evolution. We are what we ate. Nature $\mathbf{4 0 0}, 219-220$.

15. Muskiet FAJ (2005) Evolutionaire geneeskunde. U bent wat $\mathrm{u}$ eet, maar u moet weer worden wat $\mathrm{u}$ at (Evolutionary medicine. You are what you eat, but you must again be what you ate). Ned Tijdsch Klin Chem Labgeneesk 30, $163-184$

16. Barker DJ (1990) The fetal and infant origins of adult disease. BMJ 301, 1111

17. Godfrey KM \& Barker DJ (2000) Fetal nutrition and adult disease. Am J Clin Nutr 71, 1344S-1352S.

18. Drake AJ \& Walker BR (2004) The intergenerational effects of fetal programming: non-genomic mechanisms for the inheritance of low birth weight and cardiovascular risk. J Endocrinol 180, 1-16.

19. Gluckman PD, Hanson MA, Morton SM, et al. (2005) Lifelong echoes - a critical analysis of the developmental origins of adult disease model. Biol Neonate 87, 127-139.

20. Cordain L, Eades MR \& Eades MD (2003) Hyperinsulinemic diseases of civilization: more than just syndrome X. Comp Biochem Physiol A Mol Integr Physiol 136, 95-112.

21. Reaven GM (2005) The insulin resistance syndrome: definition and dietary approaches to treatment. Annu Rev Nutr 25, 391-406.

22. Pasinetti GM \& Eberstein JA (2008) Metabolic syndrome and the role of dietary lifestyles in Alzheimer's disease. $J$ Neurochem 106, 1503-1514.

23. Muskiet FA \& Kemperman RF (2006) Folate and long-chain polyunsaturated fatty acids in psychiatric disease. $J$ Nutr Biochem 17, 717-727.

24. Muskiet FA (2010) Pathophysiology and evolutionary aspects of dietary fats and long chain polyunsaturated 
fatty acids across the life cycle. In Fat Detection. Taste, Texture, and Post Ingestive Effects, pp. 19-79 [JP Montmayeur and J le Coutre, editors]. Boca Raton, FL: CRC Press Taylor \& Francis Group.

25. Muskiet FAJ \& Kuipers RS (2010) Lessons from shore-based hunter-gatherer diets in East Africa. In In Human Brain Evolution. The Influence of Freshwater and Marine Food Resources, pp. 77-103 [SC Cunnane and KM Stewart, editors]. Hoboken, NJ: Wiley-Blackwell.

26. Feige JN, Gelman L, Michalik L, et al. (2006) From molecular action to physiological outputs: peroxisome proliferatoractivated receptors are nuclear receptors at the crossroads of key cellular functions. Prog Lipid Res 45, 120-159.

27. Dobzhansky T (1964) Biology, molecular and organismic. Am Zool 4, 443-452.

28. Tinbergen N (1963) On the aims and methods of ethology. Zeit Tierpsy 20, 410-463.

29. Harris EE \& Malyango AA (2005) Evolutionary explanations in medical and health profession courses: are you answering your students' 'why' questions? BMC Med Educ 5, 16.

30. Purushotham AD \& Sullivan R (2010) Darwin, medicine and cancer. Ann Oncol 21, 199-203.

31. Williams GC \& Nesse RM (1991) The dawn of Darwinian medicine. Q Rev Biol 66, 1-22.

32. Nesse RM \& Williams GC (1994) Why We Get Sick. The New Science of Darwinian Medicine. New York: Times Books, Random House, Inc.

33. Gould SJ \& Vrba ES (1982) Exaptation - a missing term in the science of form. Paleobiology 8, 4-15.

34. Eaton SB, Eaton SB III, Sinclair AJ, et al. (1998) Dietary intake of long-chain polyunsaturated fatty acids during the Paleolithic. World Rev Nutr Diet 83, 12-23.

35. Eaton SB, Cordain L \& Lindeberg S (2002) Evolutionary health promotion: a consideration of common counterarguments. Prev Med 34, 119-123.

36. O'Keefe JH Jr \& Cordain L (2004) Cardiovascular disease resulting from a diet and lifestyle at odds with our Paleolithic genome: how to become a 21st-century hunter-gatherer. Mayo Clin Proc 79, 101-108.

37. Hahn RA, Teutsch SM, Rothenberg RB, et al. (1990) Excess deaths from nine chronic diseases in the United States, 1986. JAMA 264, 2654-2659.

38. Hill K, Hurtado AM \& Walker RS (2007) High adult mortality among Hiwi hunter-gatherers: implications for human evolution. J Hum Evol 52, 443-454.

39. Howell N (2001) Demography of the Dobe !Kung, 2nd ed. Piscataway: Aldine Transaction.

40. Hill K \& Hurtado A (1995) Ache Life History: the Ecology and Demography of a Foraging People. Piscataway: Aldine Transaction.

41. Marlowe FM (2010) The Hadza Hunter-Gatherers of Tanzania. Los Angeles: The University of California Press.

42. Eaton SB \& Eaton SBI (1999) The evolutionary context of chronic degenerative diseases. In Evolution in Health and Disease, pp. 251-259 [SC Stearns, editor]. Oxford: Oxford University Press.

43. Shephard RJ \& Roy J (1996) The Health Consequences of Modernization: Evidence from Circumpolar Peoples. Cambridge: Cambridge University Press.

44. Lindeberg S \& Lundh B (1993) Apparent absence of stroke and ischaemic heart disease in a traditional Melanesian island: a clinical study in Kitava. J Intern Med 233, $269-275$.

45. Lindeberg S, Nilsson-Ehle P, Terent A, et al. (1994) Cardiovascular risk factors in a Melanesian population apparently free from stroke and ischaemic heart disease: the Kitava study. J Intern Med 236, 331-340.
46. Trowell HC \& Burkitt DP (1981) Western Diseases: Their Emergence and Prevention. Cambridge, MA: Harvard University Press.

47. Blacklow RS (2007) Actuarially speaking: an overview of life expectancy. What can we anticipate? Am J Clin Nutr 86, 1560S-1562S.

48. Angel JL (1984) Health as a factor in the changes from hunting to developed farming in the eastern Mediterranean. In Paleopathology at the Origins of Agriculture, pp. 51-73 [MN Cohen and GJ Armelagos, editors]. New York: Academic Press.

49. Larsen CS (1995) Biological changes in human populations with agriculture. Annu Rev Anthropol 24, 185-213.

50. Larsen CS (2003) Animal source foods and human health during evolution. J Nutr 133, 3893S-3897S.

51. Larsen CS (2000) Dietary reconstruction and nutritional assessement of past peoples: the bioanthropological record. In The Cambridge World History of Food, pp. 13-34 [KF Kiple and KC Ornelas, editors]. Cambridge: Cambridge University Press.

52. Cohen MN (1984) Editors summation. In Paleopathology at the Origins of Ariculture, pp. 585-601 [MN Cohen and G] Armelagos, editors]. New York: Academic Press.

53. Mckeown T, Brown RG \& Record RG (1972) An interpretation of the modern rise of population in Europe. Popul Stud (Camb) 26, 345-382.

54. Blurton-Jones NG, Marlowe FW, Hawkes K, et al (2000) Paternal investment and hunter-gatherer divorce. In Adaptation and Human Behavior: An Anthropological Perspective, pp. 61-90 [L Cronk, N Chagnon and W Irons, editors]. New York: Aldine de Gruyter.

55. Hawkes K, O'Connell JF \& Blurton-Jones NG (2001) Hunting and nuclear families: some lessons from the Hadza about men's work. Curr Anthropol 42, 681-709.

56. Hawkes K, O'Connell JF, Jones NG, et al. (1998) Grandmothering, menopause, and the evolution of human life histories. Proc Natl Acad Sci U S A 95, 1336-1339.

57. O'Connell JF, Hawkes K \& Blurton Jones NG (1999) Grandmothering and the evolution of Homo erectus. J Hum Evol 36, 461-485.

58. Sear R, Mace R \& McGregor IA (2000) Maternal grandmothers improve nutritional status and survival of children in rural Gambia. Proc Biol Sci 267, 1641-1647.

59. Bogin B (2009) Childhood, adolescence, and longevity: a multilevel model of the evolution of reserve capacity in human life history. Am J Hum Biol 21, 567-577.

60. Hawkes K (2010) Colloquium paper: how grandmother effects plus individual variation in frailty shape fertility and mortality: guidance from human-chimpanzee comparisons. Proc Natl Acad Sci U S A 107, Suppl. 2, 8977-8984.

61. van Bodegom D, Rozing M, May L, et al. (2010) When grandmothers matter. Gerontology 56, 214-216.

62. Kachel AF, Premo LS \& Hublin JJ (2011) Grandmothering and natural selection. Proc Biol Sci 278, 384-391.

63. Strier KB, Chaves PB, Mendes SL, et al. (2011) Low paternity skew and the influence of maternal kin in an egalitarian, patrilocal primate. Proc Natl Acad Sci US A 108, 18915-18919.

64. van Bodegom D (2011) Selection for longevity in a polygamous society in rural Africa. In Post-Reproductive Survival in a Polygamous Society in Rural Africa, chapter 7, pp. 125-140. Doctoral Thesis, Leiden University.

65. Brunet M, Guy F, Pilbeam D, et al. (2002) A new hominid from the Upper Miocene of Chad, Central Africa. Nature 418, 145-151.

66. Senut B, Pickford M, Gommery D, et al. (2001) First hominid from the Miocene (Lukeino Formation, Kenya). C R Acad Sci IIA 332, 137-144. 
67. Haile-Selassie Y, Suwa G \& White TD (2004) Late Miocene teeth from Middle Awash, Ethiopia, and early hominid dental evolution. Science 303, 1503-1505.

68. White TD, Asfaw B, Beyene Y, et al. (2009) Ardipithecus ramidus and the paleobiology of early hominids. Science 326, 75-86.

69. Leakey MG, Feibel CS, McDougall I, et al. (1998) New specimens and confirmation of an early age for Australopithecus anamensis. Nature 393, 62-66.

70. Kimbel WH \& Delezene LK (2009) "Lucy" redux: a review of research on Australopithecus afarensis. Am J Phys Anthropol 140, Suppl. 49, 2-48.

71. Harrison T (2011) Hominins from the Upper Laetolil and Upper Ndolanya beds, Laetoli. In Paleontology and Geology of Laetoli: Human Evolution in Context: Volume 2: Fossil Hominins and the Associated Fauna, pp. 141-188 [T Harrison, editor]. Dordrecht: Springer.

72. Brunet M, Beauvilain A, Coppens Y, et al. (1995) The first australopithecine 2,500 kilometres west of the Rift Valley (Chad). Nature 378, 273-275.

73. Leakey MG, Spoor F, Brown FH, et al. (2001) New hominin genus from eastern Africa shows diverse middle Pliocene lineages. Nature 410, 433-440.

74. Asfaw B, White T, Lovejoy O, et al. (1999) Australopithecus garbi: a new species of early hominid from Ethiopia Science 284, 629-635.

75. Herries AI, Hopley PJ, Adams JW, et al. (2010) Letter to the Editor: Geochronology and palaeoenvironments of Southern African hominin-bearing localities - a reply to Wrangham et al., 2009. "Shallow-water habitats as sources of fallback foods for hominins". Am J Phys Anthropol 143, 640-646.

76. Tattersall I (2010) Macroevolutionary patterns, exaptation, and emergence in the evolution of the human brain and cognition. In Human Brain Evolution. The Influence of Freshwater and Marine Food Resources, pp. 1-11 [SC Cunnane and KM Stewart, editors]. Hoboken, NJ: Wiley-Blackwell.

77. Stringer C (2003) Human evolution: out of Ethiopia. Nature 423, 692-693, 695.

78. White TD, Asfaw B, DeGusta D, et al. (2003) Pleistocene Homo sapiens from Middle Awash, Ethiopia. Nature $\mathbf{4 2 3}$ 742-747.

79. Brown P, Sutikna T, Morwood MJ, et al. (2004) A new small-bodied hominin from the Late Pleistocene of Flores, Indonesia. Nature 431, 1055-1061.

80. Reich D, Patterson N, Kircher M, et al. (2011) Denisova admixture and the first modern human dispersals into Southeast Asia and Oceania. Am J Hum Genet 89, 516-528.

81. Stringer C (2000) Palaeoanthropology. Coasting out of Africa. Nature 405, 24-25, 27.

82. Templeton A (2002) Out of Africa again and again. Nature 416, 45-51.

83. Oppenheimer S (2009) The great arc of dispersal of modern humans: Africa to Australia. Quat Int 202, 2-13.

84. Templeton AR (2005) Haplotype trees and modern human origins. Am J Phys Anthropol 128, Suppl. 41, 33-59.

85. Templeton AR (2007) Genetics and recent human evolution. Evolution 61, 1507-1519.

86. Templeton AR (2010) Coherent and incoherent inference in phylogeography and human evolution. Proc Natl Acad Sci U S A 107, 6376-6381.

87. Green RE, Krause J, Ptak SE, et al. (2006) Analysis of one million base pairs of Neanderthal DNA. Nature 444, 330-336.

88. Zhivotovsky LA, Rosenberg NA \& Feldman MW (2003) Features of evolution and expansion of modern humans, inferred from genomewide microsatellite markers. Am J Hum Genet 72, 1171-1186.

89. Knight A, Underhill PA, Mortensen HM, et al. (2003) African $\mathrm{Y}$ chromosome and mtDNA divergence provides insight into the history of click languages. Curr Biol 13, 464-473.

90. Henn BM, Gignoux CR, Jobin M, et al. (2011) Hunter-gatherer genomic diversity suggests a southern African origin for modern humans. Proc Natl Acad Sci U S A 108, 5154-5162.

91. Behar DM, Villems R, Soodyall H, et al. (2008) The dawn of human matrilineal diversity. Am J Hum Genet 82, 1130-1140.

92. Ambrose SH (1998) Late Pleistocene human population bottlenecks, volcanic winter, and differentiation of modern humans. J Hum Evol 34, 623-651.

93. Rosenberg NA, Pritchard JK, Weber JL, et al. (2002) Genetic structure of human populations. Science 298, 2381-2385.

94. Washburn SL \& Lancaster CS (1968) The evolution of hunting. In Man the Hunter, pp. 293-303 [RB Lee and I DeVore, editors]. New York: Aldine Publishing Company.

95. Sailer LD, Gaulin SC, Voster JS, et al. (1985) Measuring the relationship between dietary quality and body size in primates. Primates 26, 14-27.

96. Herculano-Houzel S (2009) The human brain in numbers: a linearly scaled-up primate brain. Front Hum Neurosci 3, 31 .

97. Deaner RO, Isler K, Burkart J, et al. (2007) Overall brain size, and not encephalization quotient, best predicts cognitive ability across non-human primates. Brain Behav Evol 70, 115-124.

98. Hill RS \& Walsh CA (2005) Molecular insights into human brain evolution. Nature 437, 64-67.

99. Broadhurst CL, Cunnane SC \& Crawford MA (1998) Rift Valley lake fish and shellish provided brain-specific nutrition for early Homo. Br J Nutr 79, 3-21.

100. Cunnane SC (2010) Human brain evolution: a question of solving key nutritional and metabolic constraints on mammalian brain development. In Human Brain Evolution. The Influence of Freshwater and Marine Food Resources, pp. 33-76 [SC Cunnane and KM Stewart, editors]. Hoboken, NJ: Wiley-Blackwell.

101. Cunnane SC (2005) Origins and evolution of the Western diet: implications of iodine and seafood intakes for the human brain. Am J Clin Nutr 82, 483-484

102. Navarrete A, van Schaik CP \& Isler K (2011) Energetics and the evolution of human brain size. Nature 480, 91-93.

103. Potts R (2011) Evolution: big brains explained. Nature $\mathbf{4 8 0}$, 43-44.

104. Blinkov SM \& Glezer II (1968) The Human Brain in Figures and Tables. New York: Basic Books, Inc.

105. White DR, Widdowson EM, Woodard HQ, et al. (1991) The composition of body tissues (II). Fetus to young adult. Br J Radiol 64, 149-159.

106. Dobbing J \& Sands J (1973) Quantitative growth and development of human brain. Arch Dis Child 48, 757-767.

107. Roth G \& Dicke U (2005) Evolution of the brain and intelligence. Trends Cogn Sci 9, 250-257.

108. Herculano-Houzel S (2011) Scaling of brain metabolism with a fixed energy budget per neuron: implications for neuronal activity, plasticity and evolution. PLoS One 6, e17514

109. Herculano-Houzel S (2011) Not all brains are made the same: new views on brain scaling in evolution. Brain Behav Evol 78, 22-36.

110. Azevedo FA, Carvalho LR, Grinberg LT, et al. (2009) Equal numbers of neuronal and nonneuronal cells make the human brain an isometrically scaled-up primate brain. J Comp Neurol 513, 532-541. 
111. Herculano-Houzel S (2010) Coordinated scaling of cortical and cerebellar numbers of neurons. Front Neuroanat 4, 12

112. King MC \& Wilson AC (1975) Evolution at two levels in humans and chimpanzees. Science 188, 107-116.

113. Gu J \& Gu X (2003) Induced gene expression in human brain after the split from chimpanzee. Trends Genet 19, $63-65$.

114. Caceres M, Lachuer J, Zapala MA, et al. (2003) Elevated gene expression levels distinguish human from non-human primate brains. Proc Natl Acad Sci US A $\mathbf{1 0 0}$, 13030-13035.

115. Marques-Bonet T, Caceres M, Bertranpetit J, et al. (2004) Chromosomal rearrangements and the genomic distribution of gene-expression divergence in humans and chimpanzees. Trends Genet 20, 524-529.

116. Finlay BL \& Darlington RB (1995) Linked regularities in the development and evolution of mammalian brains. Science 268, 1578-1584.

117. Stimpson CD, Tetreault NA, Allman JM, et al. (2011) Biochemical specificity of von economo neurons in hominoids. Am J Hum Biol 23, 22-28.

118. Sherwood CC, Subiaul F \& Zawidzki TW (2008) A natural history of the human mind: tracing evolutionary changes in brain and cognition. J Anat 212, 426-454.

119. Sherwood CC, Gordon AD, Allen JS, et al. (2011) Aging of the cerebral cortex differs between humans and chimpanzees. Proc Natl Acad Sci U S A 108, 13029-13034.

120. Abzhanov A, Kuo WP, Hartmann C, et al. (2006) The calmodulin pathway and evolution of elongated beak morphology in Darwin's finches. Nature 442, 563-567.

121. Patel NH (2006) Evolutionary biology: how to build a longer beak. Nature 442, 515-516.

122. Schneider RA (2007) How to tweak a beak: molecular techniques for studying the evolution of size and shape in Darwin's finches and other birds. Bioessays 29, $1-6$.

123. Kaindl AM, Passemard S, Kumar P, et al. (2010) Many roads lead to primary autosomal recessive microcephaly. Prog Neurobiol 90, 363-383.

124. Williams CA, Dagli A \& Battaglia A (2008) Genetic disorders associated with macrocephaly. Am J Med Genet A 146A 2023-2037.

125. Evans PD, Anderson JR, Vallender EJ, et al. (2004) Adaptive evolution of ASPM, a major determinant of cerebral cortical size in humans. Hum Mol Genet 13, 489-494.

126. Evans PD, Anderson JR, Vallender EJ, et al. (2004) Reconstructing the evolutionary history of microcephalin, a gene controlling human brain size. Hum Mol Genet 13, $1139-1145$.

127. Evans PD, Gilbert SL, Mekel-Bobrov N, et al. (2005) Microcephalin, a gene regulating brain size, continues to evolve adaptively in humans. Science 309, 1717-1720.

128. Evans PD, Vallender EJ \& Lahn BT (2006) Molecular evolution of the brain size regulator genes CDK5RAP2 and CENP. J Gene 375, 75-79.

129. Speth JD (1989) Early hominid hunting and scavenging - the role of meat as an energy-source. J Hum Evol 18, 329-343.

130. Crawford MA, Bloom M, Broadhurst CL, et al. (1999) Evidence for the unique function of docosahexaenoic acid during the evolution of the modern hominid brain. Lipids 34, Suppl., S39-S47.

131. Gibbons A (2002) American Association of Physical Anthropologists meeting. Humans' head start: new views of brain evolution. Science 296, 835-837.

132. Crawford MA (2002) Cerebral evolution. Nutr Health 16, $29-34$.
133. Cordain L, Eaton SB, Sebastian A, et al. (2005) Origins and evolution of the Western diet: health implications for the 21st century. Am J Clin Nutr 81, 341-354.

134. Carlson BA \& Kingston JD (2007) Docosahexaenoic acid, the aquatic diet, and hominin encephalization: difficulties in establishing evolutionary links. Am J Hum Biol 19 $132-141$.

135. Joordens JC, Kuipers RS \& Muskiet FA (2007) Preformed dietary DHA: the answer to a scientific question may in practice become translated to its opposite. Am J Hum Biol 19, 582-584.

136. Joordens CA, Kuipers RS \& Muskiet FAJ (2005) On breast milk, diet, and large human brains. Curr Anthropol 46, $122-124$.

137. Langdon JH (2006) Has an aquatic diet been necessary for hominin brain evolution and functional development? Br J Nutr 96, 7-17.

138. Dart RA (1925) Australopithecus africanus: the man-ape of South Africa. Nature 115, 195-199.

139. Tobias PV (1998) Water and human evolution. Out There 35, 38-44.

140. Tobias PV (2010) Foreword: evolution, encephalization, environment. In Human Brain Evolution. The Influence of Freshwater and Marine Food Resources, pp. vii-xii [SC Cunnane and KM Stewart, editors]. Hoboken, NJ: Wiley-Blackwell.

141. White TD, Ambrose SH, Suwa G, et al. (2009) Macrovertebrate paleontology and the Pliocene habitat of Ardipithecus ramidus. Science 326, 87-93.

142. Cerling TE, Levin NE, Quade J, et al. (2010) Comment on the paleoenvironment of Ardipithecus ramidus. Science 328, 1105.

143. Feibel CS (2011) Anthropology: shades of the savannah. Nature 476, 39-40.

144. Cerling TE, Wynn JG, Andanje SA, et al. (2011) Woody cover and hominin environments in the past 6 million years. Nature $\mathbf{4 7 6}, 51-56$.

145. Woodburn J (1968) An introduction to Hadza ecology. In Man the Hunter, [RB Lee and I DeVore, editors]. New York: Aldine Publishing Company.

146. Tanner NM \& Zihlmann AL (1976) Women in evolution, part 1: innovation and selection in human origins. Signs 1, 585-608.

147. Stanford CB (1999) The hunting people. In The Hunting Apes: Meat Eating and the Origins of Human Behaviour, chapter 5, pp. 136-162. Princeton: Princeton University Press.

148. Cordain L, Miller JB, Eaton SB, et al. (2000) Plant-animal subsistence ratios and macronutrient energy estimations in worldwide hunter-gatherer diets. Am J Clin Nutr $\mathbf{7 1}$, 682-692.

149. Stanford CB (1999) Man the hunter and other stories. In The Hunting Apes: Meat Eating and the Origins of Human Behaviour, chapter 2, pp. 15-51. Princeton: Princeton University Press.

150. Ungar PS \& Sponheimer M (2011) The diets of early hominins. Science 334, 190-193.

151. Bernor RL (2007) New apes fill the gap. Proc Natl Acad Sci U S A 104, 19661-19662.

152. Lebatard AE, Bourles DL, Duringer P, et al. (2008) Cosmogenic nuclide dating of Sabelanthropus tchadensis and Australopithecus bahrelghazali: Mio-Pliocene hominids from Chad. Proc Natl Acad Sci U S A $\mathbf{1 0 5}$ 3226-3231.

153. Bosworth W \& Morley CK (1994) Structural and stratigraphic evolution of the Anza rift, Kenya. Tectonophysics 236, 93-115. 
154. Joordens JC (2011) The Power of Place: Climate Changes as Driver of Hominin Evolution and Dispersal over the Past Five Million Years. Amsterdam: Vrije Universiteit.

155. Vignaud P, Duringer P, Mackaye HT, et al. (2002) Geology and palaeontology of the Upper Miocene Toros-Menalla hominid locality, Chad. Nature 418, 152-155.

156. Stewart KM (2010) The case for exploitation of wetlands environments and foods by pre-sapiens hominins. In Human Brain Evolution. The Influence of Freshwater and Marine Food Resources, pp. 137-171 [SC Cunnane and KM Stewart, editors]. Hoboken, NJ: Wiley-Blackwell.

157. Pickford M \& Senut B (2001) The geological and faunal context of Late Miocene hominid remains from Lukeino, Kenya. C R Acad Sci IIA 332, 145-152.

158. WoldeGabriel G, Haile-Selassie Y, Renne PR, et al. (2001) Geology and palaeontology of the Late Miocene Middle Awash valley, Afar rift, Ethiopia. Nature 412, 175-178.

159. WoldeGabriel G, Ambrose SH, Barboni D, et al. (2009) The geological, isotopic, botanical, invertebrate, and lower vertebrate surroundings of Ardipithecus ramidus. Science 326, 65e1-65e5.

160. Feibel CS, Harris JM \& Brown FH (1991) Paleoenvironmental context for the late Neogene of the Turkana basin. In Koobi Fora Research Project, pp. 321-346 [JM Harris, editor]. Oxford: Clarendon Press.

161. Reed KE (1997) Early hominid evolution and ecological change through the African Plio-Pleistocene. J Hum Evol 32, 289-322

162. Ward C, Leakey M \& Walker A (1999) The new hominid species Australopithecus anamensis. Evol Anthropol 7, 197-205.

163. Schoeninger MJ, Reeser H \& Hallin K (2003) Paleoenvironment of Australopithecus anamensis at Allia Bay, East Turkana, Kenya: evidence from mammalian herbivore enamel stable isotopes. J Anthropol Archaeol 22, 200-207.

164. Reed KE (2008) Paleoecological patterns at the Hadar hominin site, Afar Regional State, Ethiopia. J Hum Evol 54, 743-768.

165. Su DF \& Harrison T (2008) Ecological implications of the relative rarity of fossil hominins at Laetoli. J Hum Evol 55, 672-681.

166. Veldkamp A, Buis E, Wijbrands JR, et al. (2007) Late Cenozoic fluvial dynamics of the River Tana, Kenya, an uplift dominated record. Quat Sci Rev 26, 2897-2912.

167. Sepulchre P, Ramstein G, Fluteau F, et al. (2006) Tectonic uplift and Eastern Africa aridification. Science 313, $1419-1423$.

168. Trauth MH, Maslin MA, Deino AL, et al. (2007) High- and low-latitude forcing of Plio-Pleistocene East African climate and human evolution. J Hum Evol 53, 475-486.

169. Bartoli G, Sarnthein M, Weinelt M, et al. (2005) Final closure of the Panama and the onset of northern hemisphere glaciation. Earth Planetary Sci Lett 237, 33-44.

170. Potts R (1998) Environmental hypotheses of hominin evolution. Yearb Phys Anthropol 41, 93-136.

171. Pobiner BL, Rogers MJ, Monahan CM, et al. (2008) New evidence for hominin carcass processing strategies at 1.5 Ma, Koobi Fora, Kenya. J Hum Evol 55, 103-130.

172. Ashley GM, Tactikos JC \& Owen RB (2009) Hominin use of springs and wetlands: paleoclimate and archaeological records from Olduvai Gorge $(\sim 1.79-1.74 \mathrm{Ma})$. Palaeogeogr Palaeoclimatol Palaeoecol 272, 1-16.

173. Drake NA, Blench RM, Armitage SJ, et al. (2011) Ancient watercourses and biogeography of the Sahara explain the peopling of the desert. Proc Natl Acad Sci U S A $\mathbf{1 0 8}$ $458-462$.
174. Sikes NE (1994) Early hominid habitat preferences in East-Africa - paleosol carbon isotopic evidence. J Hum Evol 27, 25-45.

175. Joordens JC, Wesselingh FP, de Vos J, et al. (2009) Relevance of aquatic environments for hominins: a case study from Trinil (Java, Indonesia). J Hum Evol 57, 656-671.

176. Popovich DG, Jenkins DJ, Kendall CW, et al. (1997) The western lowland gorilla diet has implications for the health of humans and other hominoids. J Nutr 127, 2000-2005.

177. Marshall AJ \& Wrangham RW (2007) Evolutionary consequences of fallback foods. Int J Primatol 28, 1218-1235.

178. Nishida $T$ (1980) Local differences in responses to water among wild chimpanzees. Folia Primatol 33, 189-209.

179. Sakamaki T (1998) First record of algae-feeding by a female chimpanzee at Mahale. Pan Afr News 5, 1-3.

180. Kempf E (2009) Patterns of water use in primates. Folia Primatol (Basel) 80, 275-294.

181. Wrangham R, Cheney D, Seyfarth R, et al. (2009) Shallowwater habitats as sources of fallback foods for hominins. Am J Phys Anthropol 140, 630-642.

182. Vogel ER, van Woerden JT, Lucas PW, et al. (2008) Functional ecology and evolution of hominoid molar enamel thickness: Pan troglodytes schweinfurthii and Pongo pygmaeus wurmbii. J Hum Evol 55, 60-74.

183. Suwa G, Kono RT, Simpson SW, et al. (2009) Paleobiological implications of the Ardipithecus ramidus dentition. Science 326, 94-99.

184. Teaford MF \& Ungar PS (2000) Diet and the evolution of the earliest human ancestors. Proc Natl Acad Sci U S A 97, 13506-13511.

185. Walker A, Hoeck HN \& Perez L (1978) Mecrowear of mammalian teeth as an indicator of diet. Science 201, 908-910.

186. Ungar PS, Grine FE \& Teaford MF (2008) Dental microwear and diet of the Plio-Pleistocene hominin Paranthropus boisei. Plos One 3, e2044.

187. Ungar PS, Scott RS, Grine FE, et al. (2010) Molar microwear textures and the diets of Australopithecus anamensis and Australopithecus afarensis. Philos Trans $R$ Soc B Biol Sci 365, 3345-3354.

188. Grine FE, Ungar PS, Teaford MF, et al. (2006) Molar microwear in Praeanthropus afarensis: evidence for dietary stasis through time and under diverse paleoecological conditions. J Hum Evol 51, 297-319.

189. Scott RS, Ungar PS, Bergstrom TS, et al. (2005) Dental microwear texture analysis shows within-species diet variability in fossil hominins. Nature 436, 693-695.

190. Cerling TE, Mbua E, Kirera FM, et al. (2011) Diet of Paranthropus boisei in the early Pleistocene of East Africa. Proc Natl Acad Sci U S A 108, 9337-9341.

191. Ungar P (2004) Dental topography and diets of Australopithecus afarensis and early Homo. J Hum Evol 46, 605-622.

192. Ulijaszek SJ (2002) Human eating behaviour in an evolutionary ecological context. Proc Nutr Soc 61, 517-526.

193. Goldstone AP, de Hernandez CG, Beaver JD, et al. (2009) Fasting biases brain reward systems towards high-calorie foods. Eur J Neurosci 30, 1625-1635.

194. Ungar PS, Grine FE, Teaford MF, et al. (2006) Dental microwear and diets of African early Homo.J Hum Evol 50, $78-95$.

195. Ungar PS, Grine FE \& Teaford MF (2006) Diet in early Homo: a review of the evidence and a new model of adaptive versatility. Annu Rev Anthropol 35, 209-228.

196. Perez-Perez A, De Castro JMB \& Arsuaga JL (1999) Nonocclusal dental microwear analysis of 300000 -year-old Homo 
heilderbergensis teeth from Sima de los Huesos (Sierra de Atapuerca, Spain). Am J Phys Anthropol 108, 433-457.

197. Lalueza C, PerezPerez A \& Turbon D (1996) Dietary inferences through buccal microwear analysis of middle and upper pleistocene human fossils. Am J Phys Anthropol 100, 367-387.

198. Mahoney P (2007) Human dental microwear from Ohalo II (22 500-23500 cal BP), Southern Levant. Am J Phys Anthropol 132, 489-500.

199. Mahoney P (2006) Dental microwear from Natufian huntergatherers and early neolithic farmers: comparisons within and between samples. Am J Phys Anthropol 130, 308-319.

200. Milton K (1999) Nutritional characteristics of wild primate foods: do the diets of our closest living relatives have lessons for us? Nutrition 15, 488-498.

201. Milton K (2003) The critical role played by animal source foods in human (Homo) evolution. J Nutr 133, 3886S-3892S.

202. Gittleman JL \& Thompson SD (1988) Energy allocation in mammalian reproduction. Am Zool 28, 863-875.

203. Oftedal TO (1984) Milk composition, milk yield and energy output a peak lactation: a comparative review. Symp Zool Soc Lond 51, 33-85.

204. Aiello LC \& Key C (2002) Energetic consequences of being a Homo erectus female. Am J Hum Biol 14, 551-565.

205. Aiello LC \& Wells JCK (2002) Energetics and the evolution of the genus Homo. Annu Rev Anthropol 31, 323-338.

206. Cunnane SC \& Crawford MA (2003) Survival of the fattest: fat babies were the key to evolution of the large human brain. Comp Biochem Physiol A Mol Integr Physiol 136, 17-26.

207. Leonard WR, Robertson ML, Snodgrass JJ, et al. (2003) Metabolic correlates of hominid brain evolution. Comp Biochem Physiol A Mol Integr Physiol 136, 5-15.

208. Aiello LC \& Wheeler P (1995) The expensive-tissue hypothesis - the brain and the digestive system in human and primate evolution. Curr Anthropol 36, 199-221.

209. Aiello LC (2007) Notes on the implications of the expensive tissue hypothesis for human biological and social evolution. In Guts and Brains. An Integrative Approach to the Hominin Record, pp. 17-28 [W Roebroeks, editor]. Leiden: Leiden University Press.

210. Kaufman JA, Hladik CM \& Pasquet P (2003) On the expensive-tissue hypothesis: independent support from highly encephalized fish. Curr Anthropol 44, 705-707.

211. Galdikas BM \& Wood JW (1990) Birth spacing patterns in humans and apes. Am J Phys Anthropol 83, 185-191.

212. Isler K \& van Schaik CP (2009) The expensive brain: a framework for explaining evolutionary changes in brain size. $J$ Hum Evol 57, 392-400.

213. Isler K (2011) Energetic trade-offs between brain size and offspring production: marsupials confirm a general mammalian pattern. Bioessays 33, 173-179.

214. Pontzer H, Raichlen DA \& Sockol MD (2009) The metabolic cost of walking in humans, chimpanzees, and early hominins. J Hum Evol 56, 43-54.

215. Wrangham RW, Jones JH, Laden G, et al. (1999) The raw and the stolen. Cooking and the ecology of human origins. Curr Anthropol 40, 567-594.

216. Robinson BW \& Wilson DS (1998) Optimal foraging, specialization, and a solution to Liem's paradox. Am Nat 151, 223-235.

217. Harris WS (2008) You are what you eat applies to fish, too. $J$ Am Diet Assoc 108, 1131-1133.

218. Sponheimer M \& Dufour DL (2009) Increased dietary breadth in early hominin evolution: revisiting arguments and evidence with a focus on biogeochemical contributions. In The Evolution of Hominin Diets: Integrating
Approaches to the Study of Palaeolithic Subsistence, chapter 18, pp. 229-240 [J-J Hublin and MP Richards, editors]. Dordrecht: Springer.

219. Sillen A \& Kavanagh M (1982) Strontium and paleodietary research: a review. Am J Phys Anthropol 25, 67-90.

220. Sillen A (1992) Strontium calcium ratios ( $\mathrm{Sr} / \mathrm{Ca}$ ) of Australopithecus robustus and associated fauna from Swartkrans. J Hum Evol 23, 495-516.

221. Sillen A, Hall G \& Armstrong R (1995) Strontium calcium ratios $(\mathrm{Sr} / \mathrm{Ca})$ and strontium isotopic-ratios $\left({ }^{87} \mathrm{Sr} /{ }^{86} \mathrm{Sr}\right)$ of Australopithecus robustus and Homo sp. from Swartkrans. J Hum Evol 28, 277-285.

222. Conklin-Brittain NL, Wrangham RW \& Hunt KD (1998) Dietary response of chimpanzees and cercopithecines to seasonal variation in fruit abundance. II. Macronutrients. Int $J$ Primatol 19, 971-998.

223. Lee-Thorp J \& Sponheimer M (2003) Three case studies used to reassess the reliability of fossil bone and enamel isotope signals for paleodietary studies. I Anthropol Archaeol 22, 208-216.

224. Sponheimer M, de Ruiter D, Lee-Thorp J, et al. (2005) Sr/Ca and early hommin diets revisited: new data from modern and fossil tooth enamel. J Hum Evol 48, 147-156.

225. Lee-Thorp J \& Sponheimer M (2006) Contributions of biogeochemistry to understanding hominin dietary ecology. Yearb Phys Anthropol 49, 131-148.

226. Balter V \& Simon L (2006) Diet and behavior of the SaintCesaire Neanderthal inferred from biogeochemical data inversion. J Hum Evol 51, 329-338.

227. Ophel IL \& Fraser CD (1970) Calcium and strontium discrimination by aquatic plants. Ecology 51, 324-327.

228. Ambrose SH \& Deniro MJ (1986) The isotopic ecology of East-African mammals. Oecologia 69, 395-406.

229. Lee-Thorp JA, Sponheimer M, Passey BH, et al. (2010) Stable isotopes in fossil hominin tooth enamel suggest a fundamental dietary shift in the Pliocene. Phil Trans $R$ Soc Lond B Biol Sci 365, 3389-3396.

230. Sponheimer M \& Lee-Thorp JA (2006) Enamel diagenesis at South African Australopith sites: implications for paleoecological reconstruction with trace elements. Geochim Cosmochim Acta 70, 1644-1654.

231. Sponheimer M, Lee-Thorp J, de Ruiter D, et al. (2005) Hominins, sedges, and termites: new carbon isotope data from the Sterkfontein valley and Kruger National Park. J Hum Evol 48, 301-312.

232. Vogel JC (1978) Isotopic assessment of dietary habits of ungulates. S Afr J Sci 74, 298-301.

233. Cerling TE, Harris JM, MacFadden BJ, et al. (1997) Global vegetation change through the Miocene/Pliocene boundary. Nature 389, 153-158.

234. Peters CR \& Vogel JC (2005) Africa's wild C-4 plant foods and possible early hominid diets. J Hum Evol 48, 219-236.

235. Segalen L, Lee-Thorp JA \& Cerling T (2007) Timing of C-4 grass expansion across sub-Saharan Africa. J Hum Evol 53, 549-559.

236. Sponheimer M, Reed KE \& Lee-Thorp JA (1999) Combining isotopic and ecomorphological data to refine bovid paleodietary reconstruction: a case study from the Makapansgat Limeworks hominin locality. J Hum Evol 36, 705-718.

237. Lee-Thorp J, Thackeray JF \& van der Merwe N (2000) The hunters and the hunted revisited. J Hum Evol 39, 565-576.

238. Sponheimer M, Lee-Thorp JA \& de Ruiter DJ (2007) Icarus, Isotopes, and Australopith Diets. In Evolution of the Human Diet: The Known, the Unknown, and the Unknowable, pp. 132-149 [P Ungar, editor]. Oxford: Oxford University Press. 
239. Kelly JF (2000) Stable isotopes of carbon and nitrogen in the study of avian and mammalian trophic ecology. Can J Zool 78, 1-27.

240. Schoeninger MJ \& Deniro MJ (1984) Nitrogen and carbon isotopic composition of bone-collagen from marine and terrestrial animals. Geochim Cosmochim Acta 48, 625-639.

241. Mbabazi D, Makanga B, Orach-Meza F, et al. (2010) Intralake stable isotope ratio variation in selected fish species and their possible carbon sources in Lake Kyoga (Uganda): implications for aquatic food web studies. Afr J Ecol 48, 667-675.

242. Schoeninger MJ, Deniro MJ \& Tauber H (1983) Stable nitrogen isotope ratios of bone-collagen reflect marine and terrestrial components of prehistoric human diet. Science 220, 1381-1383.

243. Sponheimer M \& Lee-Thorp JA (2003) Differential resource utilization by extant great apes and australopithecines: towards solving the C-4 conundrum. Comp Biochem Physiol A Mol Integr Physiol 136, 27-34.

244. Lee-Thorp JA, Sponheimer M \& Luyt J (2007) Tracking changing environments using stable carbon isotopes in fossil tooth enamel: an example from the South African hominin sites. J Hum Evol 53, 595-601.

245. van der Merwe NJ, Masao FT \& Bamford MK (2008) Isotopic evidence for contrasting diets of early hominins Homo habilis and Australopithecus boisei of Tanzania. S Afr J Sci 104, 153-155.

246. Schoeninger MJ, Moore J \& Sept JM (1999) Subsistence strategies of two 'savanna' chimpanzee populations: the stable isotope evidence. Am J Primatol 49, 297-314.

247. Sponheimer M, Loudon JE, Codron D, et al. (2006) Do "savanna" chimpanzees consume C-4 resources? J Hum Evol 51, 128-133.

248. Sponheimer M \& Lee-Thorp JA (1999) Oxygen isotopes in enamel carbonate and their ecological significance. J Archaeol Sci 26, 723-728.

249. Sponheimer M \& Lee-Thorp JA (2001) The oxygen isotope composition of mammalian enamel carbonate from Morea Estate, South Africa. Oecologia 126, 153-157.

250. Hu Y, Shang H, Tong H, et al. (2009) Stable isotope dietary analysis of the Tianyuan 1 early modern human. Proc Natl Acad Sci U S A 106, 10971-10974.

251. Richards MP, Pettitt PB, Trinkaus E, et al. (2000) Neanderthal diet at Vindija and Neanderthal predation: the evidence from stable isotopes. Proc Natl Acad Sci U S A 97, 7663-7666.

252. Richards MP, Pettitt PB, Stiner MC, et al. (2001) Stable isotope evidence for increasing dietary breadth in the European mid-Upper Paleolithic. Proc Natl Acad Sci US A 98, 6528-6532.

253. Richards MP (2002) A brief review of the archaeological evidence for Palaeolithic and Neolithic subsistence. Eur J Clin Nutr 56, 1270-1278.

254. Richards MP, Schulting RJ \& Hedges RE (2003) Archaeology: sharp shift in diet at onset of Neolithic. Nature 425, 366.

255. Richards MP, Jacobi R, Cook J, et al. (2005) Isotope evidence for the intensive use of marine foods by Late Upper Palaeolithic humans. J Hum Evol 49, 390-394

256. Richards MP \& Trinkaus E (2009) Isotopic evidence for the diets of European Neanderthals and early modern humans. Proc Natl Acad Sci U S A 106, 16034-16039.

257. van der Merwe NJ, Thackeray JF, Lee-Thorp JA, et al. (2003) The carbon isotope ecology and diet of Australopithecus africanus at Sterkfontein, South Africa. J Hum Evol 44, 581-597.

258. Semaw S, Rogers MJ, Quade J, et al. (2003) 2.6-Millionyear-old stone tools and associated bones from
OGS-6 and OGS-7, Gona, Afar, Ethiopia. J Hum Evol 45 , 169-177.

259. McPherron SP, Alemseged Z, Marean CW, et al. (2010) Evidence for stone-tool-assisted consumption of animal tissues before 3.39 million years ago at Dikika, Ethiopia. Nature 466, 857-860.

260. Willis LA, Eren MI \& Rick TC (2008) Does butchering fish leave cut marks? J Archaeol Sci 35, 1438-1444.

261. Braun DR, Harris JW, Levin NE, et al. (2010) Early hominin diet included diverse terrestrial and aquatic animals $1.95 \mathrm{Ma}$ in East Turkana, Kenya. Proc Natl Acad Sci U S A 107, 10002-10007.

262. de Heinzelin J, Clark JD, White T, et al. (1999) Environment and behavior of 2.5-million-year-old Bouri hominids. Science 284, 625-629.

263. Leonard WR, Robertson ML \& Snodgrass JJ (2007) Energetics and the evolution of brain size in early Homo. In Guts and Brains. An Integrative Approach to the Hominin Record, pp. 29-46 [W Roebroeks, editor]. Leiden: Leiden University Press.

264. Simpson SW, Quade J, Levin NE, et al. (2008) A female Homo erectus pelvis from Gona, Ethiopia. Science 322, 1089-1092.

265. Bramble DM \& Lieberman DE (2004) Endurance running and the evolution of Homo. Nature 432, 345-352.

266. Broadhurst CL, Wang Y, Crawford MA, et al. (2002) Brainspecific lipids from marine, lacustrine, or terrestrial food resources: potential impact on early African Homo sapiens. Comp Biochem Physiol B Biochem Mol Biol 131, 653-673.

267. Erlandson JM (2001) The archaeology of aquatic adaptations: paradigms for a new millennium. I Archaeol Res 9, 287-350.

268. Marean CW (2010) Coastal South Africa and the co-evolution of the modern human lineage and the coastal adaptation. In Trekking the Shore: Changing Coastlines and the Antiquity of Coastal Settlement, pp. 421-440 [N Bicho, JA Haws and LG Davis, editors]. New York: Springer.

269. Stewart KM (1994) Early hominid utilization of fish resources and implications for seasonality and behavior. J Hum Evol 27, 229-245.

270. Wang S, Lewis CM, Jakobsson M, et al. (2007) Genetic variation and population structure in native Americans. PLOS Genet 3, e185.

271. Pope GG (1989) Bamboo and human-evolution. In Natural History, pp. 48-57, October 1989.

272. Fagan BM (1990) The Journey from Eden: The Peopling of Our World. London: Thames and Hudson.

273. Bar-Yosef O (1994) The lower Paleolithic of the Near East. $J$ World Prehist 8, 211-265.

274. Cleyet-Merle J \& Madelaine S (1995) Inland evidence of human sea coast exploitation in Palaeolithic France. In Man and Sea in the Mesolithic, pp. 303-308 [A Fischer, editor]. Oxford: Oxbow Books.

275. Klein RG, Avery G, Cruz-Uribe K, et al. (1999) Duinefontein 2, an Acheulean Site in the Western Cape Province of South Africa. J Hum Evol 37, 153-190.

276. de Lumley H (1969) A Paleolithic camp at Nice. In Scientific American, vol. 220, pp. 42-50.

277. Villa P (1983) Terra Amata and the Middle Pleistocene Archaeological Record of Southern France (University of California Publications in Anthropology). Berkeley: University of California Press.

278. Marean CW, Bar-Matthews M, Bernatchez J, et al. (2007) Early human use of marine resources and pigment in South Africa during the Middle Pleistocene. Nature 449, 905-908. 
279. Walter RC, Buffler RT, Bruggemann JH, et al. (2000) Early human occupation of the Red Sea coast of Eritrea during the last interglacial. Nature 405, 65-69.

280. Stiner MC (1993) Honor Among Thieves: A Zooarchaeological Study of Neandertal Ecology. Princeton, NJ: Princeton University Press.

281. von den Driesch A (2004) The Middle Stone Age fish fauna from the Klassies River main site, South Africa. Anthropozoologica 39, 33-59.

282. Erlandson JM (2010) Food for thought: the role of coastlines and aquatic resources in human evolution. In Human Brain Evolution: The Influence of Freshwater and Marine Food Resources, pp. 125-136 [SC Cunnane and KM Stewart, editors]. Hoboken, New Jersey: Wiley-Blackwell.

283. Klein RG, Cruz-Uribe K, Halkett D, et al. (1999) Paleoenvironmental and human behavioral implications of the Boegoeberg 1 late pleistocene hyena den, Northern Cape Province, South Africa. Quatern Res 52, 393-403.

284. Marean CW, Goldberg P, Avery G, et al. (2000) Middle Stone Age stratigraphy and excavations at Die Kelders Cave 1 (Western Cape Province, South Africa): the 1992, 1993, and 1995 field seasons. J Hum Evol 38, 7-42.

285. Henshilwood C \& Sealy J (1997) Bone artifacts from the Middle Stone Age at Blombos Cave, southern cape, South Africa. Curr Anthropol 38, 890-895.

286. Klein RG, Avery G, Cruz-Uribe K, et al. (2004) The Ysterfontein 1 Middle Stone Age site, South Africa, and early human exploitation of coastal resources. Proc Natl Acad Sci U S A 101, 5708-5715.

287. Avery G, Halkett D, Orton J, et al. (2008) The Ysterfontein 1 Middle Stone Age rock shelter and the evolution of coastal foraging. S Afr Archaeol Soc Goodwin Ser 10, 66-89.

288. Henshilwood C, d'Errico F, Vanhaeren M, et al. (2004) Middle Stone Age shell beads from South Africa. Science 304, 404 .

289. Harris JW, Williamson PG, Morris PJ, et al (1990) Archaeology of the Lusso beds. In Evolution of Environments and Hominidae in the African Western Rift Valley, pp. 237-272 [NT Boaz, editor]. Martinsville: Virginia Museum of Natural History.

290. Meylan P (1990) Fossil turtles from the upper Semliki, Zaire. In Evolution of Environments and Hominidae in the African Western Rift Valley, pp. 163-170 [NT Boaz, editor]. Martinsville: Virginia Museum of Natural History.

291. Henshilwood CS, Sealy JC, Yates R, et al. (2001) Blombos Cave, Southern Cape, South Africa: preliminary report on the 1992-1999 excavations of the Middle Stone Age levels. J Archaeol Sci 28, 421-448.

292. Wickler S \& Spriggs M (1988) Pleistocene human occupation of the Solomon-Islands, Melanesia. Antiquity 62, 703-706.

293. Allen J, Gosden C, Jones R, et al. (1988) Pleistocene dates for the human occupation of New Ireland, northern Melanesia. Nature 331, 707-709.

294. O'Connor S, Ono R \& Clarkson C (2011) Pelagic fishing at 42000 years before the present and the maritime skills of modern humans. Science 334, 1117-1121.

295. Morwood MJ, O'Sullivan PB, Aziz F, et al. (1998) Fissiontrack ages of stone tools and fossils on the east Indonesian island of Flores. Nature 392, 173-176.

296. Morwood MJ, Aziz F, O'Sullivan P, et al. (1999) Archaeological and palaeontological research in central Flores, east Indonesia: results of fieldwork 1997-98. Antiquity 73, 273-286.

297. Morwood MJ, Brown P, Jatmiko, et al. (2005) Further evidence for small-bodied hominins from the Late Pleistocene of Flores, Indonesia. Nature 437, 1012-1017.
298. Westaway KE, Morwood MJ, Roberts RG, et al. (2007) Establishing the time of initial human occupation of Liang Bua, western Flores, Indonesia. Quat Geochronol 2, 337-343.

299. Brumm A, Jensen GM, van den Bergh GD, et al. (2010) Hominins on Flores, Indonesia, by one million years ago. Nature 464, 748-752.

300. Sept JM (1986) Plant foods and early hominids at Site Fxij 50, Koobi-Fora, Kenya. J Hum Evol 15, 751-770.

301. Gibbons A (2007) Paleoanthropology. Food for thought. Science 316, 1558-1560.

302. Wobber V, Hare B \& Wrangham R (2008) Great apes prefer cooked food. J Hum Evol 55, 340-348.

303. Goren-Inbar N, Alperson N, Kislev ME, et al. (2004) Evidence of hominin control of fire at Gesher Benot Ya'aqov, Israel. Science 304, 725-727.

304. Roebroeks W \& Villa P (2011) On the earliest evidence for habitual use of fire in Europe. Proc Natl Acad Sci US A $\mathbf{1 0 8}$ 5209-5214.

305. Henry AG, Brooks AS \& Piperno DR (2011) Microfossils in calculus demonstrate consumption of plants and cooked foods in Neanderthal diets (Shanidar III, Iraq; Spy I and II, Belgium). Proc Natl Acad Sci U S A 108, 486-491.

306. Crawford MA, Bloom M, Cunnane S, et al. (2001) Docosahexaenoic acid and cerebral evolution. World Rev Nutr Diet 88, 6-17.

307. Parkington J (2003) Middens and moderns: shellfishing and the Middle Stone Age of the Western Cape, South Africa. $S$ Afr J Sci 99, 243-247.

308. Parkington J, Roggenpoel C, Halkett D, et al (2009) Initial observations on the Middle Stone Age coastal settlement in the Western Cape, South Africa. In Settlement Dynamics of the Middle Paleolithic and Middle Stone Age, pp. 5-22 [NJ Conard, editor]. Tubingen: Tubingen Publications in Prehistory.

309. Cordain L, Eaton SB, Sebastian A, et al. (2005) Origins and evolution of the Western diet: implications of iodine and seafood intakes for the human brain - reply. Am J Clin Nutr 82, 483-484.

310. Nadel D, Weiss E, Simchoni O, et al. (2004) Stone Age hut in Israel yields world's oldest evidence of bedding. Proc Natl Acad Sci U S A 101, 6821-6826.

311. Weiss E, Wetterstrom W, Nadel D, et al. (2004) The broad spectrum revisited: evidence from plant remains. Proc Natl Acad Sci U S A 101, 9551-9555.

312. Kislev ME, Weiss E, Hartmann A \& Hartmann A (2004) Impetus for sowing and the beginning of agriculture: ground collecting of wild cereals. Proc Natl Acad Sci US A 101, 2692-2695.

313. Kimbel WH, Walter RC, Johanson DC, et al. (1996) Late Pliocene Homo and Oldowan tools from the Hadar formation (Kada Hadar Member), Ethiopia. J Hum Evol 31, 549-561.

314. Lee RB (1968) What hunters do for a living, or, how to make out on scarce resources. In Man the Hunter, pp. 30-48 [RB Lee and I DeVore, editors]. New York: Aldine Publishing Company.

315. Murdock GV (1967) Ethnographic Atlas. Pittsburgh: University of Pittsburgh Press.

316. Stewart JH (1968) Causal factors and processes in the evolution of pre-farming societies. In Man the Hunter, pp. 321-334 [RB Lee and I DeVore, editors]. New York: Aldine Publishing Company.

317. Meehan B (1982) Shell Bed to Shell Midden. Canberra: Humanity Press.

318. Moss ML (1993) Shellfish, gender, and status on the Northwest Coast - reconciling archaeological, ethnographic, and 
ethnohistorical records of the Tlingit. Am Anthropol 95 631-652.

319. Godfrey KM, Lillycrop KA, Burdge GC, et al. (2007) Epigenetic mechanisms and the mismatch concept of the developmental origins of health and disease. Pediatr Res 61, 5R-10R.

320. Burdge GC, Hanson MA, Slater-Jefferies JL, et al. (2007) Epigenetic regulation of transcription: a mechanism for inducing variations in phenotype (fetal programming) by differences in nutrition during early life? Br J Nutr 97, $1036-1046$.

321. Waterland RA \& Jirtle RL (2004) Early nutrition, epigenetic changes at transposons and imprinted genes, and enhanced susceptibility to adult chronic diseases. Nutrition 20, 63-68.

322. Lillycrop KA \& Burdge GC (2010) Epigenetic changes in early life and future risk of obesity. Int J Obes (Lond) $\mathbf{3 5}$, $72-83$.

323. Godfrey KM, Sheppard A, Gluckman PD, et al. (2011) Epigenetic gene promoter methylation at birth is associated with child's later adiposity. Diabetes 60, 1528-1534.

324. Bensinger SJ \& Tontonoz P (2008) Integration of metabolism and inflammation by lipid-activated nuclear receptors. Nature 454, 470-477.

325. Castrillo A \& Tontonoz P (2004) PPARs in atherosclerosis: the clot thickens. J Clin Invest 114, 1538-1540.

326. Song Y, Yao X \& Ying H (2011) Thyroid hormone action in metabolic regulation. Protein Cell 2, 358-368.

327. Bouillon R, Bischoff-Ferrari H \& Willett W (2008) Vitamin D and health: perspectives from mice and man. J Bone Miner Res 23, 974-979.

328. McGrane MM (2007) Vitamin A regulation of gene expression: molecular mechanism of a prototype gene. J Nutr Biochem 18, 497-508.

329. Venturi S, Donati FM, Venturi A, et al. (2000) Role of iodine in evolution and carcinogenesis of thyroid, breast and stomach. Adv Clin Path 4, 11-17.

330. Kohrle J \& Gartner R (2009) Selenium and thyroid. Best Pract Res Clin Endocrinol Metab 23, 815-827.

331. Gilbert ME, McLanahan ED, Hedge J, et al. (2011) Marginal iodide deficiency and thyroid function: dose-response analysis for quantitative pharmacokinetic modeling. Toxicology 283, 41-48.

332. Desvergne B \& Wahli W (1999) Peroxisome proliferatoractivated receptors: nuclear control of metabolism. Endocr Rev 20, 649-688.

333. Norman AW \& Bouillon R (2010) Vitamin D nutritional policy needs a vision for the future. Exp Biol Med (Maywood) 235, 1034-1045.

334. Holick MF \& Chen TC (2008) Vitamin D deficiency: a worldwide problem with health consequences. Am J Clin Nutr 87, 1080S-1086S.

335. Mann GV, Roels OA, Price DL, et al. (1962) Cardiovascular disease in African Pygmies. A survey of the health status, serum lipids and diet of Pygmies in Congo. J Chron Dis 15, 341-371

336. Mann GV, Shaffer RD, Anderson RS, et al. (1964) Cardiovascular disease in the Masai. $J$ Atheroscler Res 4 289-312.

337. Mann GV, Shaffer RD \& Rich A (1965) Physical fitness and immunity to heart disease in Masai. Lancet ii, 1308-1310.

338. Shaper AG, Leonard PJ, Jones KW, et al. (1969) Environmental effects on the body build, blood pressure and blood chemistry of nomadic warriors serving in the army in Kenya. East Afr Med J 46, 282-289.

339. O'Keefe JH Jr, Cordain L, Harris WH, et al. (2004) Optimal low-density lipoprotein is 50 to $70 \mathrm{mg} / \mathrm{dl}$ : lower is better and physiologically normal. I Am Coll Cardiol 43, 2142-2146.

340. Joffe BI, Jackson WP, Thomas ME, et al. (1971) Metabolic responses to oral glucose in the Kalahari Bushmen. $\mathrm{Br}$ Med J 4, 206-208.

341. Merimee TJ, Rimoin DL \& Cavalli-Sforza LL (1972) Metabolic studies in the African pygmy. I Clin Invest 51, 395-401.

342. Ramsden CE, Faurot KR, Carrera-Bastos P, et al. (2009) Dietary fat quality and coronary heart disease prevention: a unified theory based on evolutionary, historical, global, and modern perspectives. Curr Treat Options Cardiovasc Med 11, 289-301.

343. Keys AB (1980) Seven Countries: A Multivariate Analysis of Death and Coronary Heart Disease. Cambridge, MA: Harvard University Press.

344. Clarke R, Frost C, Collins R, et al. (1997) Dietary lipids and blood cholesterol: quantitative meta-analysis of metabolic ward studies. BMJ 314, 112-117.

345. Kuipers RS, de Graaf DJ, Luxwolda MF, et al. (2011) Saturated fat, carbohydrates and CVD. Neth J Med 69, 22-28.

346. Ho KJ, Biss K, Mikkelson B, et al. (1971) The Masai of East Africa: some unique biological characteristics. Arch Pathol 91, 387-410.

347. Biss K, Ho KJ, Mikkelson B, et al. (1971) Some unique biologic characteristics of the Masai of East Africa. $N$ Engl J Med 284, 694-699.

348. Mann GV, Spoerry A, Gray M, et al. (1972) Atherosclerosis in the Masai. Am J Epidemiol 95, 26-37.

349. Kaminer B \& Lutz WPW (1960) Blood pressure in Bushmen of the Kalahari Desert. Circulation 22, 289-295.

350. Clement AJ, Fosdick LL \& Plotkin R (1956) The formation of lactic acid in dental plaques. II. Oral conditions of primitive Bushmen of the Western Kalahari Desert. J Dent Res 35, 786-791.

351. Lindeberg S, Berntorp E, Nilsson-Ehle P, et al. (1997) Age relations of cardiovascular risk factors in a traditional Melanesian society: the Kitava Study. Am J Clin Nutr 66, $845-852$

352. Sackett DL, Rosenberg WM, Gray JA, et al. (1996) Evidence based medicine: what it is and what it isn't. BMJ 312, $71-72$.

353. Blumberg J, Heaney RP, Huncharek M, et al. (2010) Evidence-based criteria in the nutritional context. Nutr Rev 68, 478-484.

354. Dyerberg J, Bang HO \& Hjorne N (1975) Fatty acid composition of the plasma lipids in Greenland Eskimos. Am J Clin Nutr 28, 958-966.

355. Bang HO, Dyerberg J \& Sinclair HM (1980) The composition of the Eskimo food in north western Greenland. Am J Clin Nutr 33, 2657-2661.

356. Burr ML, Fehily AM, Gilbert JF, et al. (1989) Effects of changes in fat, fish, and fibre intakes on death and myocardial reinfarction: diet and reinfarction trial (DART). Lancet ii, $757-761$.

357. Mozaffarian D \& Rimm EB (2006) Fish intake, contaminants, and human health: evaluating the risks and the benefits. JAMA 296, 1885-1899.

358. de Lorgeril M, Salen P, Martin JL, et al. (1999) Mediterranean diet, traditional risk factors, and the rate of cardiovascular complications after myocardial infarction: final report of the Lyon Diet Heart Study. Circulation 99, 779-785.

359. Anonymous (1999) Dietary supplementation with $n-3$ polyunsaturated fatty acids and vitamin $\mathrm{E}$ after myocardial infarction: results of the GISSI-Prevenzione trial. Gruppo Italiano per lo Studio della Sopravvivenza nell'Infarto miocardico. Lancet 354, 447-455. 
360. Marchioli R, Barzi F, Bomba E, et al. (2002) Early protection against sudden death by $n-3$ polyunsaturated fatty acids after myocardial infarction: time-course analysis of the results of the Gruppo Italiano per lo Studio della Sopravvivenza nell'Infarto Miocardico (GISSI)-Prevenzione. Circulation 105, 1897-1903.

361. Yokoyama M, Origasa H, Matsuzaki M, et al. (2007) Effects of eicosapentaenoic acid on major coronary events in hypercholesterolaemic patients (JELIS): a randomised open-label, blinded endpoint analysis. Lancet 369, 1090-1098.

362. Kromhout D, Giltay EJ, Geleijnse JM, et al. (2010) n-3 Fatty acids and cardiovascular events after myocardial infarction. N Engl J Med 363, 2015-2026.

363. Hibbeln JR (1998) Fish consumption and major depression. Lancet 351, 1213.

364. Hibbeln JR (2002) Seafood consumption, the DHA content of mothers' milk and prevalence rates of postpartum depression: a cross-national, ecological analysis. J Affect Disord 69, 15-29.

365. Hibbeln JR (2009) Depression, suicide and deficiencies of omega-3 essential fatty acids in modern diets. World Rev Nutr Diet 99, 17-30.

366. Hibbeln JR (2001) Seafood consumption and homicide mortality. A cross-national ecological analysis. World Rev Nutr Diet 88, 41-46.

367. Lin PY \& Su KP (2007) A meta-analytic review of double-blind, placebo-controlled trials of antidepressant efficacy of omega-3 fatty acids. J Clin Psychiatry 68, 1056-1061.

368. Ross BM, Seguin J \& Sieswerda LE (2007) Omega-3 fatty acids as treatments for mental illness: which disorder and which fatty acid? Lipids Health Dis 6, 21.

369. Sinclair AJ, Begg D, Mathai M, et al. (2007) Omega 3 fatty acids and the brain: review of studies in depression. Asia Pac J Clin Nutr 16, Suppl. 1, 391-397.

370. Freeman MP (2000) Omega-3 fatty acids in psychiatry: a review. Ann Clin Psychiatry 12, 159-165.

371. Freeman MP, Hibbeln JR, Wisner KL, et al. (2006) Omega-3 fatty acids: evidence basis for treatment and future research in psychiatry. J Clin Psychiatry 67, 1954-1967.

372. Sublette ME, Ellis SP, Geant AL, et al. (2011) Meta-analysis of the effects of eicosapentaenoic acid (EPA) in clinical trials in depression. J Clin Psychiatry 72, 1577-1584.

373. Wellcome Trust Case Control Consortium (2007) Genomewide association study of 14000 cases of seven common diseases and 3,000 shared controls. Nature 447, 661-678.

374. Challem JJ (1997) Did the loss of endogenous ascorbate propel the evolution of Anthropoidea and Homo sapiens? Med Hypotheses 48, 387-392.

375. Nishikimi M, Fukuyama R, Minoshima S, et al. (1994) Cloning and chromosomal mapping of the human nonfunctional gene for L-gulono- $\gamma$-lactone oxidase, the enzyme for L-ascorbic acid biosynthesis missing in man. $J$ Biol Chem 269, 13685-13688.

376. Burdge GC \& Wootton SA (2002) Conversion of $\alpha$-linolenic acid to eicosapentaenoic, docosapentaenoic and docosahexaenoic acids in young women. Br J Nutr 88, 411-420.

377. Burdge GC (2006) Metabolism of $\alpha$-linolenic acid in humans. Prostaglandins Leukot Essent Fatty Acids 75, 161-168.

378. Kuipers RS, Luxwolda MF, Janneke Dijck-Brouwer DA, et al. (2011) Intrauterine, postpartum and adult relationships between arachidonic acid (AA) and docosahexaenoic acid (DHA). Prostaglandins Leukot Essent Fatty Acids 85, $245-252$.

379. Luxwolda MF, Kuipers RS, Smit EN, et al. (2011) The relation between the omega-3 index and arachidonic acid is bell shaped: synergistic at low EPA + DHA status and antagonistic at high EPA + DHA status. Prostaglandins Leukot Essent Fatty Acids 85, 171-178.

380. Crawford MA, Hassam AG, Williams G, et al. (1976) Essential fatty acids and fetal brain growth. Lancet $\mathbf{i}$, $452-453$.

381. Kuhn DC \& Crawford M (1986) Placental essential fatty acid transport and prostaglandin synthesis. Prog Lipid Res 25, $345-353$.

382. Crawford MA, Hassam AG \& Rivers JP (1978) Essential fatty acid requirements in infancy. Am J Clin Nutr 31, 2181-2185.

383. Hornstra G (2000) Essential fatty acids in mothers and their neonates. Am J Clin Nutr 71, 1262S-1269S

384. Hornstra G (2005) Essential fatty acids during pregnancy. Impact on mother and child. Nestle Nutr Workshop Ser Pediatr Program 55, 83-96.

385. Makrides M, Gibson RA, McPhee AJ, et al. (2010) Effect of DHA supplementation during pregnancy on maternal depression and neurodevelopment of young children: a randomized controlled trial. JAMA 304, 1675-1683.

386. Doornbos B, van Goor SA, Dijck-Brouwer DA, et al. (2009) Supplementation of a low dose of DHA or DHA + AA does not prevent peripartum depressive symptoms in a small population based sample. Prog Neuropsychopharmacol Biol Psychiatry 33, 49-52.

387. Su KP, Huang SY, Chiu TH, et al. (2008) Omega-3 fatty acids for major depressive disorder during pregnancy: results from a randomized, double-blind, placebo-controlled trial. J Clin Psychiatry 69, 644-651.

388. Wojcicki JM \& Heyman MB (2011) Maternal omega-3 fatty acid supplementation and risk for perinatal maternal depression. J Matern Fetal Neonatal Med 24, 680-686.

389. Koletzko B \& Braun M (1991) Arachidonic acid and early human growth: is there a relation? Ann Nutr Metab 35, 128-131.

390. Szajewska H, Horvath A \& Koletzko B (2006) Effect of $n$-3 long-chain polyunsaturated fatty acid supplementation of women with low-risk pregnancies on pregnancy outcomes and growth measures at birth: a meta-analysis of randomized controlled trials. Am J Clin Nutr 83, 1337-1344.

391. Olsen SF, Osterdal ML, Salvig JD, et al. (2006) Duration of pregnancy in relation to seafood intake during early and mid pregnancy: prospective cohort. Eur J Epidemiol 21, 749-758.

392. Olsen SF, Osterdal ML, Salvig JD, et al. (2007) Duration of pregnancy in relation to fish oil supplementation and habitual fish intake: a randomised clinical trial with fish oil. EurJ Clin Nutr 61, 976-985.

393. Malcolm CA, McCulloch DL, Montgomery C, et al. (2003) Maternal docosahexaenoic acid supplementation during pregnancy and visual evoked potential development in term infants: a double blind, prospective, randomised trial. Arch Dis Child Fetal Neonatal Ed 88, F383-F390.

394. Malcolm CA, Hamilton R, McCulloch DL, et al. (2003) Scotopic electroretinogram in term infants born of mothers supplemented with docosahexaenoic acid during pregnancy. Invest Ophthalmol Vis Sci 44, 3685-3691.

395. Judge MP, Harel O \& Lammi-Keefe CJ (2007) A docosahexaenoic acid-functional food during pregnancy benefits infant visual acuity at four but not six months of age. Lipids 42, 117-122.

396. Birch EE, Carlson SE, Hoffman DR, et al. (2010) The DIAMOND (DHA Intake And Measurement Of Neural Development) Study: a double-masked, randomized controlled clinical trial of the maturation of infant visual acuity as a function of the dietary level of docosahexaenoic acid. $\mathrm{Am}$ J Clin Nutr 91, 848-859. 
397. Smithers LG, Gibson RA, McPhee A, et al. (2008) Higher dose of docosahexaenoic acid in the neonatal period improves visual acuity of preterm infants: results of a randomized controlled trial. Am JClin Nutr 88, 1049-1056.

398. Judge MP, Harel O \& Lammi-Keefe CJ (2007) Maternal consumption of a docosahexaenoic acid-containing functional food during pregnancy: benefit for infant performance on problem-solving but not on recognition memory tasks at age 9 mo. Am J Clin Nutr 85, 1572-1577.

399. Dunstan JA, Simmer K, Dixon G, et al. (2008) Cognitive assessment of children at age 2(1/2) years after maternal fish oil supplementation in pregnancy: a randomised controlled trial. Arch Dis Child Fetal Neonatal Ed 93, F45-F50.

400. Helland IB, Smith L, Saarem K, et al. (2003) Maternal supplementation with very-long-chain $n-3$ fatty acids during pregnancy and lactation augments children's IQ at 4 years of age. Pediatrics 111, e39-e44.

401. Helland IB, Smith L, Blomen B, et al. (2008) Effect of supplementing pregnant and lactating mothers with $n$-3 verylong-chain fatty acids on children's IQ and body mass index at 7 years of age. Pediatrics 122, e472-e479.

402. McCann JC \& Ames BN (2005) Is docosahexaenoic acid, an n-3 long-chain polyunsaturated fatty acid, required for development of normal brain function? An overview of evidence from cognitive and behavioral tests in humans and animals. Am J Clin Nutr 82, 281-295.

403. Dijck-Brouwer DA, Hadders-Algra M, Bouwstra $\mathrm{H}$, et al. (2005) Lower fetal status of docosahexaenoic acid, arachidonic acid and essential fatty acids is associated with less favorable neonatal neurological condition. Prostaglandins Leukot Essent Fatty Acids 72, 21-28.

404. Moriguchi T, Loewke J, Garrison M, et al. (2001) Reversal of docosahexaenoic acid deficiency in the rat brain, retina, liver, and serum. J Lipid Res 42, 419-427.

405. Rao JS, Ertley RN, DeMar JC Jr, et al. (2007) Dietary n-3 PUFA deprivation alters expression of enzymes of the arachidonic and docosahexaenoic acid cascades in rat frontal cortex. Mol Psychiatry 12, 151-157.

406. van Goor SA, Smit EN, Schaafsma A, et al. (2008) Milk of women with lifetime consumption of the recommended daily intake of fish fatty acids should constitute the basis for the DHA contents of infant formula. J Perinat Med 36, 548-549.

407. Brenna JT, Varamini B, Jensen RG, et al. (2007) Docosahexaenoic and arachidonic acid concentrations in human breast milk worldwide. Am J Clin Nutr 85, 1457-1464

408. Koletzko B, Lien E, Agostoni C, et al. (2008) The roles of long-chain polyunsaturated fatty acids in pregnancy, lactation and infancy: review of current knowledge and consensus recommendations. J Perinat Med 36, 5-14.

409. Kuipers RS, Smit EN, van der Meulen J, et al. (2007) Milk in the island of Chole [Tanzania] is high in lauric, myristic, arachidonic and docosahexaenoic acids, and low in linoleic acid reconstructed diet of infants born to our ancestors living in tropical coastal regions. Prostaglandins Leukot Essent Fatty Acids 76, 221-233.

410. Hachey DL, Silber GH, Wong WW, et al. (1989) Human lactation. II: Endogenous fatty acid synthesis by the mammary gland. Pediatr Res 25, 63-68.

411. Kabara JJ (1980) Lipids as host-resistance factors of human milk. Nutr Rev 38, 65-73.

412. Bergsson G, Steingrimsson O \& Thormar H (2002) Bactericidal effects of fatty acids and monoglycerides on Helicobacter pylori. Int J Antimicrob Agents 20, 258-262.

413. Widdowson EM, Dauncey MJ, Gairdner DM, et al. (1975) Body fat of British and Dutch infants. Br Med J 1, 653-655.
414. Ailhaud G, Massiera F, Weill P, et al. (2006) Temporal changes in dietary fats: role of $n-6$ polyunsaturated fatty acids in excessive adipose tissue development and relationship to obesity. Prog Lipid Res 45, 203-236.

415. Ramsden CE, Hibbeln JR, Majchrzak SF, et al. (2010) n-6 Fatty acid-specific and mixed polyunsaturate dietary interventions have different effects on CHD risk: a metaanalysis of randomised controlled trials. Br J Nutr 104, $1586-1600$.

416. Harris WS, Mozaffarian D, Rimm E, et al. (2009) Omega-6 fatty acids and risk for cardiovascular disease: a science advisory from the American Heart Association Nutrition Subcommittee of the Council on Nutrition. Circulation 119, 902-907.

417. Gibson RA, Muhlhausler B \& Makrides M (2011) Conversion of linoleic acid and $\alpha$-linolenic acid to long-chain polyunsaturated fatty acids (LCPUFAs), with a focus on pregnancy, lactation and the first 2 years of life. Matern Child Nutr 7, Suppl. 2, 17-26.

418. Koletzko B, Thiel I \& Abiodun PO (1992) The fatty acid composition of human milk in Europe and Africa. J Pediatr 120, S62-S70.

419. Godfrey K, Robinson S, Barker DJ, et al. (1996) Maternal nutrition in early and late pregnancy in relation to placental and fetal growth. BMJ 312, 410-414.

420. Innis SM \& Kuhnlein HV (1988) Long-chain $n-3$ fatty acids in breast milk of Inuit women consuming traditional foods. Early Hum Dev 18, 185-189.

421. Ruan C, Liu X, Man H, et al. (1995) Milk composition in women from five different regions of China: the great diversity of milk fatty acids. J Nutr 125, 2993-2998.

422. Muskiet FA, Kuipers RS, Smit EN, et al. (2007) The basis of recommendations for docosahexaenoic and arachidonic acids in infant formula: absolute or relative standards? Am J Clin Nutr 86, 1802-1803.

423. Willett WC (2002) Balancing life-style and genomics research for disease prevention. Science 296, 695-698.

424. Yudkin J (1963) Dietary carbohydrate and ischemic heart disease. Am Heart J 66, 835-836.

425. Yudkin J (1967) Evolutionary and historical changes in dietary carbohydrates. Am J Clin Nutr 20, 108-115.

426. Eaton SB (1992) Humans, lipids and evolution. Lipids 27, $814-820$

427. Cordain L, Watkins BA \& Mann NJ (2001) Fatty acid composition and energy density of foods available to African hominids. Evolutionary implications for human brain development. World Rev Nutr Diet 90, 144-161.

428. Crawford MA (1968) Fatty-acid ratios in free-living and domestic animals. Possible implications for atheroma. Lancet i, 1329-1333.

429. O'Dea K \& Sinclair AJ (1982) Increased proportion of arachidonic acid in plasma lipids after 2 weeks on a diet of tropical seafood. Am J Clin Nutr 36, 868-872.

430. Sinclair AJ, O'Dea K \& Naughton JM (1983) Elevated levels of arachidonic acid in fish from northern Australian coastal waters. Lipids 18, 877-881.

431. Gibson RA, Kneebone R \& Kneebone GM (1984) Comparative levels of arachidonic acid and eicosapentaenoic acid in Malaysian fish. Comp Biochem Physiol C 78, 325-328.

432. Naughton JM, O'Dea K \& Sinclair AJ (1986) Animal foods in traditional Australian aboriginal diets: polyunsaturated and low in fat. Lipids 21, 684-690.

433. Konner M \& Eaton SB (2010) Paleolithic nutrition: twentyfive years later. Nutr Clin Pract 25, 594-602.

434. Eaton SB, Eaton SB III \& Konner MJ (1997) Paleolithic nutrition revisited: a twelve-year retrospective on its nature and implications. Eur J Clin Nutr 51, 207-216. 
435. Eaton SB \& Eaton SB III (2000) Paleolithic vs. modern diets - selected pathophysiological implications. Eur J Nutr 39, $67-70$.

436. Cordain L, Miller JB, Eaton SB, et al. (2000) Macronutrient estimations in hunter-gatherer diets. Am J Clin Nutr $\mathbf{7 2}$, $1589-1592$

437. Kuipers RS, Luxwolda MF, Dijck-Brouwer DA, et al. (2010) Estimated macronutrient and fatty acid intakes from an East African Paleolithic diet. Br J Nutr 104, 1666-1687.

438. Morgan E (1997) The Aquatic Ape Hypothesis. London: Souvenir Press.

439. Horrobin DF (2001) The Madness of Adam and Eve. How Schizophrenia Shaped Humanity. Reading: Cox \& Wyman Ltd.

440. Hotamisligil GS \& Erbay E (2008) Nutrient sensing and inflammation in metabolic diseases. Nat Rev Immunol 8, 923-934.

441. Forsythe CE, Phinney SD, Fernandez ML, et al. (2008) Comparison of low fat and low carbohydrate diets on circulating fatty acid composition and markers of inflammation. Lipids 43, 65-77.

442. Volek JS, Phinney SD, Forsythe CE, et al. (2009) Carbohydrate restriction has a more favorable impact on the metabolic syndrome than a low fat diet. Lipids $\mathbf{4 4}$, 297-309.
443. Forsythe CE, Phinney SD, Feinman RD, et al. (2010) Limited effect of dietary saturated fat on plasma saturated fat in the context of a low carbohydrate diet. Lipids 45, 947-962.

444. Simopoulos AP (1999) Essential fatty acids in health and chronic disease. Am J Clin Nutr 70, 560S-569S.

445. Simopoulos AP (2001) Evolutionary aspects of diet and essential fatty acids. World Rev Nutr Diet 88, 18-27.

446. Feinman RD \& Volek JS (2006) Low carbohydrate diets improve atherogenic dyslipidemia even in the absence of weight loss. Nutr Metab (Lond) 3, 24.

447. Osterdahl M, Kocturk T, Koochek A, et al. (2008) Effects of a short-term intervention with a Paleolithic diet in healthy volunteers. Eur J Clin Nutr 62, 682-685.

448. Jönsson T, Granfeldt Y, Ahrén B, et al. (2009) Beneficial effects of a Paleolithic diet on cardiovascular risk factors in type 2 diabetes: a randomized cross-over pilot study. Cardiovasc Diabetol 8, 35.

449. Lindeberg S, Jonsson T, Granfeldt Y, et al. (2007) A Palaeolithic diet improves glucose tolerance more than a Mediterranean-like diet in individuals with ischaemic heart disease. Diabetologia 50, 1795-1807.

450. Frassetto LA, Schloetter M, Mietus-Synder M, et al. (2009) Metabolic and physiologic improvements from consuming a Paleolithic, hunter-gatherer type diet. Eur J Clin Nutr 63, 947-955. 